


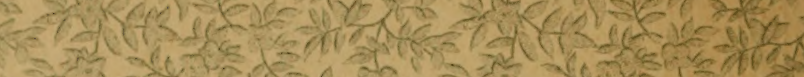

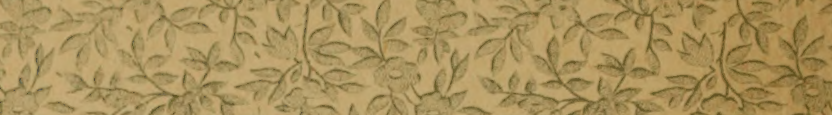
1.

.8

Columbitia College in the oity of Jien zloxk

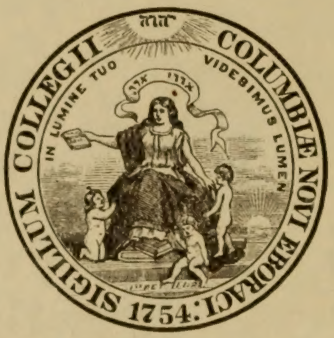

gibraxy.

GIVEN BY

n by Di. N. L. Britutard

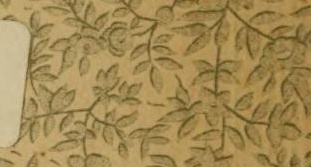

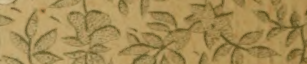
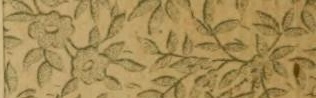

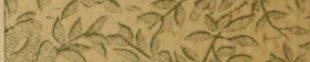

1 alcita

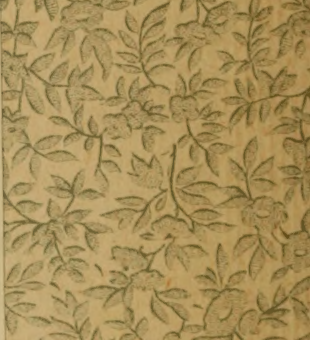

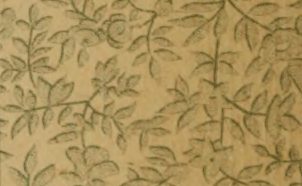






complinents

OT. Rathroch

CATALOGUE

OF

\section{TREES AND SHRUBS}

NATIVE OF AND INTRODUCED IN THE

\section{HORTICULTURAL GARDENS}

ADJACENT TO

\section{HORTICULTURAL HALL,}

FAIRMOUNT PARK, ry.

PHILADELPHIA. 


$$
\begin{aligned}
& \text { QK } \\
& 484 \\
& . P 4 \\
& \text { C38 }
\end{aligned}
$$




\section{PREFACE.}

IN the following pages there has been no attempt made at original work. On the contrary, the standard writings of Gray, Engelmann, Chapman, De Candolle, Parlatore, Andersson, Loudon, and Gordon have been freely used. It is hoped that the names given will be found correct. It is, however, fair to say that in some instances it was not deemed wise to adopt the latest nomenclature, because, first, it is not yet accepted by the garden authorities or recognized by amateur botanists, and hence might confuse rather than aid ; and, secondly, there is no authoritative manual accessible in which they are so accepted. This reserve, then, is to be considered in the interest of prudence and not of exact science.

The alphabetical arrangement of orders, genera, and species is a sin against botanical law, but appears to be demanded by the needs of the Park.

The number of synonymes quoted has not been from choice, but for the obvious purpose of aiding in the recognition of a species under its most common disguises of name. It is the more a matter of regret, as it has often caused the exclusion of statements and descriptions of greater general interest. The star $\left(^{*}\right)$ means that the plants opposite are yet desired.

Philadelphia, March, 1880 . 



\title{
CATALOGUE
}

\author{
OF \\ TREES AND SHRUBS \\ ADJACENT TO \\ HORTICULT URAL HALL.
}

\section{ANACARDIACE $Æ$. Sumach or Cashew Family.}

Trees or shrubs, often with a colored or milky juice; leaves without stipules and alternate; flowers small, parts in fives except the pistil, which is single (having, however, 3 stigmas), one-celled, and one-seeded; petals 5. Our single genus (Sumach) has some species that are poisonous by proximity as well as by contact. Bark of some species used for tanning, and leaves of others for dyeing, and the milk of another in Japan for lacquering.

Rhus aromatica, Aiton. Fragrant Sumach. A low, straggling, native bush, with pale yellow scaly flowers appearing before the 3 small, toothed, aromatic (when crushed) leaflets.

Rhus copallina, Linnaus. Dwarf Sumach, Native shrub, I to 7 feet high, with young shoots and leaf-stalks downy; leaves often 2 feet long; leaflets from 9 to 21 , winged along the central axis; fruit covered with acid, crimson hairs.

Rhus Cotinus, Linnaus. Venetray Sumach, Swoke-Tree, Fuss and Feathers. European shrub, 6 to 8 feet high. Leaves smooth, ovate; fruit half heart-shaped, and falling earby, leaves the feathery stalks, to suggest the name Smoke-Tree.

Rhus glabra, Linneus. Sмооти Suмacr. Native shrub, 6 to 12 feet high, with leaves bright green above and white beneath; fruit with acid, crimson hairs.

Rhus trilobata, Nultall. From the Southwest, and regarded as a mere variely of R'hus aromatica, Ailon. 
Rhus typhina, Linnaus. Staghorn Sumach. Native in the Park. Large shrub, with branches and leaf-stalks densely velvety-hairy; fruit with acid, crimson hairs; wood yellow.

\section{ANONACEAE. Custard-Apple Family.}

Trees or shrubs; 3 sepals, 6 petals in 2 sets; stamens many, surrounding the fleshy pistils, which when ripe form a pulpy and often edible fruit; seeds large, flat, and bony. Order characterized by no special properties except the aromatic.

Asimina triloba, Dunal. PAPAw. Small native tree, ranging from New York to Illinois and southward; fruit 3 inches long and edible.

\section{AQUIFOLIACE $Æ$. Holly Family.}

Trees or shrubs; leaves simple; flowers white, small ; stamens and cells of the ovary of the same number; a single ovule or seed suspended from the summit of each cell. Cultivated for the foliage chiefly.

Ilex Aquifolium, Linnaus. European Holry. A much-branched, low, stiff tree, with thick, spiny-toothed leaves; flowers white and berries red. Neither the varieties which it has produced nor itself are entirely hardy here.

Ilex glabra, Gray. INK-BERRY. Low native shrub, with a fondness for the coast; leaves coriaceous evergreen, shining above, often black-dotted beneath; fruit black. Common enough in New Jersey.

* Ilex levigata, Gray. Smooth WinterberRy. A low native shrub, with smooth, lanceolate leaves. Common in the mountains of Pennsylvania.

Ilex mollis, Gray. Low shrub from Burgoon's Gap, in Central Pennsylvania; leaves thin, ovate or oblong, and soft downy on the under surface.

Ilex opaca, Aiton. American Holly. A hardy, white-barked, smooth, native tree, with oval, wavy margined, and spiny-toothed leaves; berries red, conspicuous in Christmas ornaments. Has an extended range along our Eastern coast.

Ilex verticillata, Gray. Black Alder, Winterberry. Native shrub, with oval, pointed leaves, which are downy on the veins beneath; white flowers in clusters; bright scarlet fruit, showy. Common in low grounds.

Ilex variegata, var. Waterii, Ilex falcata, and two new varieties from Japan appear on the Park list.

\section{ARALIACEÆ. Ginseng Family.}

Of this family but a single species need be noted here:

Aralia spinosa, Linncus. Angelica Tree, Hercules' Club. Has large, flat-topped, compound clusters of snall, perfect or imperfect, dull-colored 
flowers: 5 styles and 5 colls to the black or dark-purple, pulpy, stone-heceded fruit; stem and stalks prickly; leaves large, compound, of many leaflets. A large, unatuactive native shrub. The ginseng of commeree is furnished by other species of Aralia.

\section{BERBERIDACEA. Barberry Family.}

"Perfect flowers, with a stamen in front of each of the [separate] petals; anthers opening by valves like trap-doors, hinged at the top." Plants have acid, bitter, and astringent qualities. Flowers yellow.

Berberis Aquifolium, Pursh. Oregon Grape. Shrub 2 to 6 feet high, frum West Coast region: leaflets 7 , green, shiming on upper surface, distinctly spiny-toothed; flowers clustered in the axils of the leaves. Has often been confounded with the following:

* Berberis repens, Linilley. MuUntain Grape. Shrub less than a foot high; leaves of 3 to 7 leaflets, not shining on the upper surface; flowers clustered on the ends of the stems. Ranges from the Pacific coast eastward to the mountains of Coloralo, where the fruit, after much fermentation and sugar, makes a bad substitute for wine.

Berberis Canadensis, Pursh. American Barberry. A small shrub frum the Southern Allerhanies; leaves wavy margined, teeth slightly loristleperinted; yellow flowers few, in a cluster; petals notched at the apex; berries red, oval. Not much valued for planting.

Berberis Japonica, De Candolle. JAPA. BARBFRRY. Shrub several feet high: leaves large, rigid, with 3 or 4 spiny teeth on either side; fruit-clusters dark purple, very ornamental.

Berberis vulgaris. ELROPFAN B.IRBFRRY. Upright foreign slirub, with the leaves on the young branches reduced to spines, from the axils of which the next season's clusters of oblong bristle-toothed leaves proceed; flowers many, in a drooping cluster; scarlet berries, narrowly oblong. The Park has alos the varieties asperma and purpurea, the latter having dark-purjle lease. The relaterl pecie B'. Findleri, Gray, from New Mexico, is somewhat showy. and might endure here.

Akebia quinata, a recent introduction from Japan, belongs here.

\section{BETULACEÆ. Birch Family.}

Trees or shruls with alternate leaves; pistils and stamens in separate ataly clusters on the same tree, 2 or 3 flowers under each scale. Wood valuable; bisk enratice, used as a paper, for moking cances, for tiles covering bounes. for tanning leather; spray used for smoking fish. The peculiar odor of "Russia leather" is derived from the birch oil used in tanning.

Alnus. AlDER. Differs from the Birch only by minute floral characters. It usually has a distinct, 5-parted calyx and 2-celled anthers; scales of the

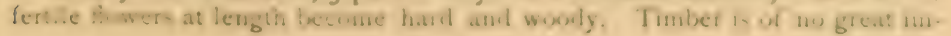


portance, being too small, though under certain circumstances it is durable enough.

Alnus firma, Siebold and Zuccarini. Branching, thick-trunked shrub, from Japan.

Alnus glutinosa, Willdenore. European Alder. Tree from Europe, 30 to 40 feet high, rapid grower, and said to be hardy. It has the following varieties: * imperialis asplenifolia. IMPERIAL FERN-LEAVED ALDER. With deeply-cut foliage, and slender, graceful growth. Recently introduced. laciniata. CUT-I.EAVED ALDER, Large and handsome; showy leaves, deeply cleft. Hardy.

* Alnus maritima, Muhlenberg. Seaside Alder. Small tree, growing along streams in Delaware and Maryland; flowers in September, fruit develops next season; leaves oblong, with a wedge-shaped base, green or rusty on lower surface.

Alnus serrulata, Aiton. Smooth Alder. A mere shrub, 6 feet high. The commun Alder of the Northern States as far west as Wisconsin.

Betula. Birch. Has 3 sterile flowers under each scale; 4 stamens, each with a $\mathbf{I}$-celled anther; 2 to 3 fertile flowers under a 3 -lobed scale; seed with a broad wing.

Betula alba, Linnceus. White Birch. Tree of northern parts the world around. 50 to 60 feet high; outer bark white, readily separated. A striking tree in grounds. There are the following varieties in the Park: pendula. With slender, drooping branches. From this, again, we have the garden forms laciniata, with delicately-cut leaves, and Youngii. populifera, Spach, is our Middle State form, has slender leaf-stalks, which cause the very long pointed leaves to tremble in the slightest breeze. Tree 15 to 20 feet high. purpurea. PURPLe-LeAved Birch. With a rich purple-colored foliage. pyramidalis. PYramidal Birch. A slender, spire-like variety, with a rich green foliage.

Betula lenta, Linnaus. Cherry Birch, Stveet or Black Birch. Native tree of good size, with clear dark-brown bark and a rose-colored timber which is valuable in cabinet-work; heart-shaped leaves, closely double-toothed; scales of the fruiting flower-clusters " with short divergent lobes."

Betula lutea, Michaux the younger. Yellow or Gray Birch. (Betula excelsa of American authors.) A good-sized native tree, with yellow or gray bark peeling off in thin layers; wood white, and of less importance than that of the preceding species; leaves slightly, if at all, heart-shaped.

Betula nigra, Linnaus. River or Ren BIRCH. (Betula nigra, Michaux the younger.) A large tree, ranging from Massachusetts southward and westward; wood light-colored, and leaves resembling those of the Alder.

Betula papyracea, Aiton. PAPER or CANOE Birch. A large tree, with close-grained wood and strong bark which peels easily and which is used in making the birch-bark canoes of the Northern waters. This species ranges widely over the northern parts of the Continent, reaching sparingly into Pennsylvania. 


\section{BIGNONIACEA. Bignonia Family.}

Usually woody plants, with conspicuous, irregular flowers; fruit mostly a pod containing many flat, winged seeds. The family is absent from Europe and the Mediterranean region, but largely developed in the warmer parts of the two Americas. Some species yield dyes, others timber, and a few produce drugs:

Bignonia capreolata, Linnous. Cross-Vine. Climbing shrub, native to

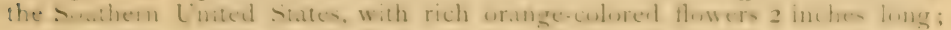
leaves made up of 4 ovate leaflets and a branched tendril. The popular name comes from a rude Maltese cross being found on a transverse section of the stem.

Catalpa. Trees with simple leaves and white or yellowish-white flowers I which may lie somew hat dosted withing in harge piramindal clu-iess; pod tong, slender, nearly straight, with the partition at right angles to the valves.

Catalpa bignonioides, Wiater. Tree native of the Siutheantern States; bark light gray, exfoliating constantly, and hence not more than three lines thick; leaves heart-shaped, and with an unpleasant odor when bruised; flowers $I^{2} / 3$ inches in each diameter, with the lower lobe entire; seeds $21 / 2$ to 3 lines wide. Long confounded with the following:

Catalpa speciosa, Warder. Tree native of the Mississippi Valley from Illinois south; bark dark, only exfoliating slightly; $1 / 2$ to 1 inch thick; leaves inodorous, slender-pointed; "flowers 2 inches in the vertical and a little more in the transverse diameter ;" fruit $3 \frac{1}{2}$ to 4 lines wide. Tree larger than the preceding, of more straight growth, and wood of great value as posts and railroad-ties from its imperishable character. It is now largely planted in the West to meet those demands in future.

Catalpa Kaempferi, — ? From Japan. I.eaves smooth, 3-angled or lobed, and flowers much smaller than those of the preceding species.

Catalpa Bungei, — ? A lately-introduced dwarf, with stout branches and very large leaves.

Tecoma. Trumpet-Flower, Trumpet-Crffeper. The species we have differ from Bignonia in having a 5 -toothed calyx, pods flattened at right angles to the partitions, and in climbing by routlets instead of by tendrils. Sume unimportant uses are made of certain tropical species.

Tecoma grandiflora, Delaun. ChINese Trimpet-Crefrer. A cultivared species from China and Japan; wicle-mouthed flower, 3 inches long. This is ahout the northern limit of its hardiness in this country. Called in cultivation Bignonia grandiflora.

Tecoma radicans, Jussicu. AMericas TrLMPET-Creppler. Native from Maryland south; flower tubular funnel-shaped,-i.e., narrower than the preceding. Called by florists Bignomia radicans. 


\section{CALYCANTHACEÆ. Calycanthus Family.}

Shrubs with opposite leaves; flower-leaves (sepals and petals) resembling one another on the same flower, often many of them; fruit hollow like a rosehip. Flower mostly dull-colored, large, usually highly aromatic, as is also the wood.

Calycanthus. Carolina Allspice, Sweet-Scented Shrub. "Flowers livid purple or dull red, solitary in the axils [of the leaves] or terminating leafy branches."

Calycanthus floridus, Linnaus. Oval leaves, downy on the under surface. The common "shrub" of the gardens. Native of the States to the south of us, where the bark is said to be used as a substitute for cinnamon.

Calycanthus glaucus, Willdenoze. The taper-pointed leaves glaucouswhite on the under surface and slightly rough above, 5 to 6 inches long. From the mountains of the Southern States.

Calycanthus lævigatus, Wilidenozv. Oblong leaves thin, green, and nearly smooth on either surface. Found from Southern Pennsylvania southward.

Calycanthus occidentalis, Hooker and Arnott. Leaves ovate, heartshaped at base, large, green on either surface, and slightly rough on the upper one; flowers brick-red, 3 inches across. Native of California.

Chimonanthus. Flowers yellowish or purplish, growing along shoots from which the leaves have fallen. Our single species in the Park is

Chimonanthus fragrans, Lindley. A half-climbing shrub from Japan, with lance-shaped, pointed, smooth leaves; flowers small, but fragrant. Long known in catalogues as Calycanthus pracox. Barely hardy here.

\section{CAMELLIACEA. Tea Family.}

Woody plants, with alternate, feather-veined leaves; flowers large and handsome, usually growing in the axils of the leaves; fruit a thick or woody 5celled, 5- or more seeded pod; petals often united at the base.

Stuartia pentagyna, L'Héritier. A fine shrub from the mountains of the Southern States, with whitish, cream-colored flowers 3 inches across, the sepals of which are slightly tinged outside with red; styles 5. Hardy. Stuartia Faponica is also in the collection. The well-known Camellias belong here, as also the Tea-plant of commerce : the latter is fairly hardy in the Southern United States, and may sometime become of importance there.

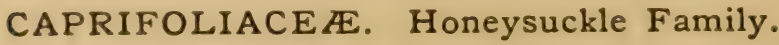

Shrubs (as a rule) with calyx and ovary united, the latter 2-to 5-celled; stamens of the same number as, and borne on, the petals, which are more or 
less united; leaves opposite; stipules none. A family with many showy flowers, and having some astringent and purgative properties among its representatives.

Diervilla. Bush-Honeysuckle. The taper pointed ovary crowned by slender calyx teeth; fruit a many-seeded pod; flower regular, or nearly so, and funnel-form. Low shrubs, usually free bloomers. Much confusion exists as to what forms now in cultivation can be regarded as genuine natural species and what mere garden varieties.

Diervilla Japonica. De Candolle. A low, vigorous shrub, native of China and Japan. It produces a profusion of rose colored flowers an inch or more long. Commonly known in gardens as Weigela rosea. In the opinion of Josiah Hoopes, all the following may be regarded as forms of this species: $D$. arborea grandiflora; $D$. amabilis; $D$. Desboisi; $D$. Gronencegeni; $D$. hortensis; $D$. Isolene; D. purpurata; D. Stellzneri; with a host of less striking ones.

Diervilla multiflora, _ ? Hoopes regards this, with its small, deepcrimson flowers, as a quite distinct species.

* Diervilla sessilifolia, Bucklcy. From the Southern Alleghanies. Has sessile, ovate-lanceolate leaves and small yellow flowers.

* Diervilla trifida, Mönch. Is a native of this region. Leaves oblong, taper-pointed, with petioles; flowers light yellow, $3 / 4$ of an inch long.

Leycesteria is related to the genus Lonicera, but has 5 cells and many seeds in its mature fruit. The single species we have is

Leycesteria formosa, Wallich. A branching shrub, with hollow branchlets, and broadly lance-shaped, sharp-pointed leaves on hairy font-stalks; flowers white and purple tinged, disposed in clusters at the ends of the branches; berry intensely purple. From the Himalaya and Khasia mountain regions.

Lonicera. HoNeysuckles. Tubular flower, irregular, more or less bulging on one side; ovary 2 - to 3 -celled and few-seeded.

Lonicera alpigena, Linnaus. Erect; leaves ovate or broadly lanceshaped, smooth or nearly so; berries united in pairs, red. From the Alps of Europe. Lonicera Sibirica of the gardens is probably but a variety of the above.

Lonicera brachypoda, De Candolle. New JAPAN Evergreen HoneysUCKL.R. Stem twining; young branches covered with spreading hairs; flowers fragrant, white and yellow. From Japan. Hoopes considers Lonicera Halliana as a form of the above.

* Lonicera Caprifolium, Linnaus. European Honeysuckl.E. Stems twining; flowers purple and white, or yellowish inside, fragrant; leaves smooth. "Flowers in early summer."

* Lonicera ciliata, Muhlenberg. EARI.y FLy Honeysucki.e. An erect native shrub, much branched; thin leaves hairy on the under surface; yellow flower, $3 / 4$ of an inch long, "l base of flower very unequal-sided ;" berries not united in pairs. 
Lonicera Etrusca, Santi. Italian or Perpetual Honeysuckle. Twining, and much like $L$. Caprifolium (see above), except that the leaves are downy and more blunt. It flowers through the summer.

Lonicera flava, Sime. Yellow Honeysuckle. Native twiner; flower 2-lipped, light yellow; leaves thick, nearly oval, and nearly white on both surlaces,

* Lonicera grata, Aiton. American Woodbine. Twiner; flower 2-lipped, white, with a slender pink tube; leaves obovate, smooth, white on the under surface only. From the Southern States.

Lonicera hirsuta, Eaton. HaIRy Honeysuckle. Flower yellow, stickypubescent; leaves large, dull green, and hairy on the lower surface. From the Northern woods.

* Lonicera involucrata, Banks. Upright shrub; flowers yellow, clammy, and embraced below by 4 large leaf-like bracts. Native of America from Wisconsin to California.

Lonicera confusa, De Candolle. JAPAN or Chinese Honeysuckle. Twiner, with separate somewhat hairy leaves; flowers in pairs from the axils of the leaves, fragrant, reddish outside and white or yellow within. Known in gardens as Lonicera faponica.

Lonicera oblongifolia, Muhlenberg. Swamp Honeysuckle. Upright native shrub; flower deeply 2 -lipped, $1 / 2$ inch long; berry purple; 4 small bracts or leaves underneath the flowers.

Lonicera Tartarica, Linncus. TARTARIAN Honeysuckle. Erect branching European shrub, with ovate, heart-shaped leaves, short flower, and bright orange or scarlet berries which are united in pairs. The white-flowered form is $L$. Pyrenaica, and the red-flowered is $L$. Sibirica, of the gardens.

Lonicera Xylosteum, Linnœus. An erect hairy shrub; leaves entire, ovate or narrower; flowers in pairs on a foot-stalk; fruits united at the base, round. From the Caucasian region. Known in Europe as the BoNY-WOODED FLY HONEYSUCKLE. Has produced some varieties.

Sambucus. ElDER. Shrubs with compound (pinnate), more or less toothed leaves, and a 3 -seeded berry; flowers small, but forming flat-topped masses.

Sambucus Canadensis, Linnaus. Common Elder. Shrub, native; leaves of 7 to II leaflets; flowers in June, and ripens its black or black-purple fruit in August; pith white. Berries and flowers of some importance in domestic economy.

Sambucus nigra, Linnaus. Shrub from Europe and Asia; one form, laciniata, has the leaves deeply cut, resembling a fringe; and another, variegata, has the leaves well marked with pale yellow bands.

Sambucus pubens, Michaux. Reid-Berrien Einer. Taller and harder than the common Elder; leaves of 5 to 7 lenflets; fruit bright red; flowers in May and matures its fruit in June; pith brown. Native. A variety with much-dissected leaves is not uncommon. 
Symphoricarpus. Shrubs with flowers in cluster, bell-nhaped; fruit a 4-celled but only 2 -seeded berry (the contents of two cells abort). Symphoria is a modification of the same name.

Symphoricarpus racemosus, Michanx. SxownerRY. Native shrul, with whitish or rose-colored flowers loosely arranged among the leaves at the ends of the branches; large berries clear white. Hardy and popular.

Symphoricarpus vulgaris, Mhihaux. INDIAN CURRANT, CURAI, BERRY. Native shrub, with whitish rose-colored flowers in close clusters in the axils of the leaves; berries small and dark red. Has produced many varieties, the best known of which is variegata, with yellow-blotched leaves.

Viburnum. ARROwWOOD. Shrubs with simple leaves; fruit containing a single convex or round stone.

* Viburnum acerifolium, Linnans. Maple-Leaved Viburnum, Dock. MACKıE. A low, rather slender, native shrub, with leaves lobed like a sugar maple and 3 to 5 inches across; flowers small, whitish, and in a flat-topped cluster; fruit red.

Viburnum Lentago, Linnous. Native shrub or small tree, 15 to 20 feet high; ovate sharp-pointed leaves, sharply toothed; flowers white, in a large flat-topped cluster; berries bluish black, stones flat and hardly marked.

Viburnum Lantana, Linnaus. WAyfaring Tree. A much-branched shrub, with younger parts mealy downy; heart-shaped leaves 3 to 5 inches acruss: flowers small and white, in dense flat-topped clusters, the marginal ones like the others.

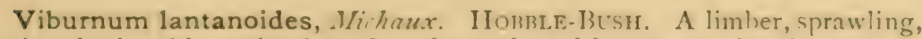
native shrub, with ronting branches; heart-shaped leaves 4 to 6 inches across; younger parts with a mealy down, especially the lower surface of the leaf-veins; marginal flowers of the cluster large and sterile, central ones small and fertile; seed with 6 grooves. Cold damp woods.

Viburnum Opulus, Linnaus. Cranberry-Tree. Native shrub, 5 to ro feet high; leaves wedge-shaped or squarely cut off at base, lobes toothed towards the apex; flowers marginal and central, as in the preceding species. The sour fruit is used as a bad substitute for cranberries. The Snozv-Ball T'ree or Guelder Rose is a cultivated form of this.

Viburnum plicatum, Thunberg. A showy Japanese species, which produces large masses of pure white flowers, and which has produced some striking varieties.

\section{CELASTRACEA. Staff-Tree Family.}

Shrubs with simple leaves; stamens on a ring-like disk in the bottom of the calyx, and which sometimes grows over the 2-to 5-celled ovary; seeds partially or entirely enclosed in a soft bag-like covering. Some few reputed remedies and fewer dyes are furnished by the group.

Celastrus. Staff-Tree. Flowers having pistils and stamens both in the

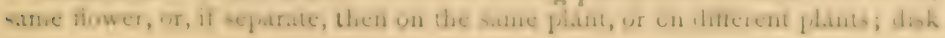


a mere ring at bottom of calyx; leaves alternate; fruit round. Our single species is

Celastrus scandens, Linnaus. WAX-Work, Climbing BitTer-Siveet. A native climber, with inconspicuous greenish flowers on the ends of the branches; open fruit yellow inside, revealing the bright scarlet seed-cover. Hence the beauty of the plant in autumn.

Euonymus. SPINDLE-TREe. Flowers perfect; disk so large as almost to conceal the young 3 - to 5 -lobed fruit; leaves opposite.

Euonymus Americanus, Linnaus. American Strawberry-Bush. A low native shrub, with thick ovate leaves and a rough 3 -lobed fruit, which is bright scarlet when matured; flowers greenish purple.

Euonymus atropurpureus, Facquin. BUrning Bush, Spindle-Tree. Tall native shrub, with oblong leaves and a smooth 4-lobed fruit; flowers dark purple.

Euonymus Europæus, Linnaus. European Spindle-Tree, Burning BusH. A low European shrub, with lance- or oblong-shaped leaves and a smooth 4-lobed fruit; the bag enclosing the seed bright orange-yellow. This species has developed two varieties, i.e., albus and coccineus.

Euonymus Japonicus, Thunberg. JAPAn Spindle-Tree, Chinese Box. Hardy only south of us. It, too, has produced a number of varieties.

Euonymus latifolius, $C$. Bauhin. Broad-Leaved Spindle-Tree. From Southern Europe. Leaves broadly ovate, and the fruit with acute lobes or wings.

\section{CONIFERÆ. Pine Family.}

Trees or shrubs which often secrete resin; leaves usually stiff, and often needle-like; flowers not conspicuous, having the pistils and stamens separated, the former open and often under a more or less hard scale (as in the cones), the latter in smaller, softer, often yellowish, scaly clusters. There are about 200 species over the globe. Wood important as a lumber, and sometimes as a fuel; bark of some (Hemlock) useful in tanning, and seeds of some species (i.e., Piñon Pine) furnishing food to races of men.

Abies. Spruces. The latest general revision of the trees and shrubs known to botanists as Coniferæ is by Parlatore, and appears in the second part of vol. xvi. of De Candolle's Prodromus. In it he divides the entire order into two tribes, -i.e., the cone-bearers proper, which he designates Abietinea, and the Taxinea, of which (latter) the Yew is a type. Under the genus Pinus of Linnæus he makes the following sections: Pinea, Cembra, Cedrus, Larix, Pseudolarix, Picea, Abies, and Tsuga. This would relegate to the old genus Pinus most of our American Coniferæ. There appears to be so little disposition to accept his classification that we have retained such groups as Abies (Spruces ${ }^{x}$ ) and Picea (Firs) as distinct. The smaller group of Tsuga

1 It is not practicable at present in this Catalogue to name the Spruces Picea, and the Firs Abies, as Dr. Engelmann insists should be done, and doubtless as would be done in a strictly scientific work. 
(Hemlock-spruce) we have placed under Abies, which, for our purpone, may be defined thus:

Abies. Leaves flat and 2-ranked, or scattered, and more or less plainly 4-angled; cones drooping, and scales not falling away.

Abies alba, Michaux. White or Single Spruce. (Pinus alba, ${ }^{x}$ Ailon; Picea alba, Limk.) Tree 50 feet high; leaves glaucous green, $1 / 3$ to $\frac{31}{4}$ of an inch lung; cones $\mathbf{I}$ to 2 inches long, oblong or cylindrical. Hardy and handsome. United States and far northward. This is different from Abies alba, Miller, which is Picea pectinata, the common Silver Fir of the Alps.

There are the following varieties: glauca, Plumbly; tree full size; leaves white, silvery. minima, Knight. SMALlest SYRUCE; leaves thickly set, spreading, glaucous. nana, Loudon; a dense dwarf bush, 3 to 4 feet high.

Abies Alcockiana, Lindley and Veilch. Alcock's Spruck. (Pinus Alcoquiuna, Parlatore: Picea Alcockiana, Carriere.) Tree 100 feet high; leaves small; branchlets rough; cones reddish, pendulous, 2 to 3 inches long. Jupan, on the sacred mountain of Fusi-Yama, at an altitude of 6000 to 7000 feet.

Abies Brunoniana, Iindley. INI)IAN Heminck-SrRuce. (Pinus dumosa, Don; Abies dumosa, Loudon; Tsuga Brunoniana, Carriere; Picea Brunoniana, Spack.) India, 70 to 80 feet high. Hardy here.

Abies Canadensis, Michaux. Hemlock-Spruce. (Pinus Canadensis, Linnous: Picen Canadensis, link; Isusa (imadinsis, Carriere.) Largetree, the pride of our cooler forests, with a straight trunk and drooping branchlets; cones small; leaves bright green on the upper surface and grayish white on the lower. Hardy and well adapted for ornamental planting. Ranges from Hudson Bay to the mountains of North Carolina, and in Northern regions, far to the westward. Timber only second-rate. Under this species we have the varieties-microphylla, Lindley; a hardy dwarf, leaves small, dark green, and rough on the edges. Milfordensis, Young; dwarf, globular in form; shoots slender, drooping; leaves smaller than in the species. nana, Lazuson; 2 to 3 feet high; foliage spreading tufty. Besides these are enumeratedhemispharica, Hoopes; inverta, Hoopes; nana nigra, Hoopes; pendula; Sargenti; Shotwelliana; variegata.

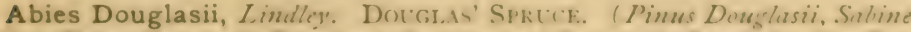

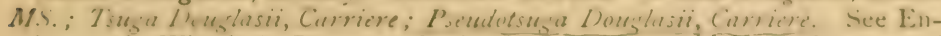
gelmann, in Wheeler's Report, vol. vi. p. 257.) Tree which on the coast of Oregon and adjacent region attains a height of 300 to 350 feet, with a corresponding diameter. In mountain-regions from Colorado to Mexico it is smaller, though still a giant. Hardy, and has produced among others the following varieties: fastigiata, Knight; conical, compact, branches ascending.

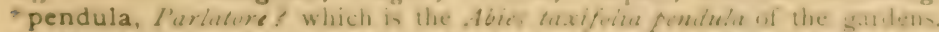

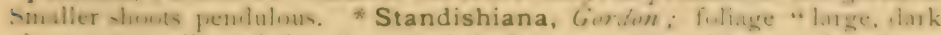
glossy green, silvery below." "Stairii, Horl.; variegated leaves of a silvery

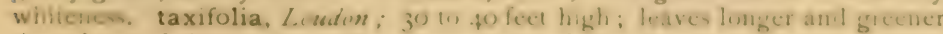
than those of the species. From mountains of Mexico.

The nomenclature of the Comifere is so confused that we are obliged (most reluctantly) to quote the more important synonymes, thus taking space which more willingly would have been devoted 10 a fuller description of the trees themselves. 
Abies Engelmanni, Parry. Engelmann's Spruce. (Pinus commutata, Parlatore; Picea Engelmanni, Engelmann.) Fine tree, with dark foliage, 40 to $\mathbf{I} 0 \mathrm{feet}$ high, according to situation. Ranges from British Columbia south to Mexico along the main mountain-chain. Requires cold situations.

Abies excelsa, De Candolle. Norway Spruce. (Pinus Abies, Du Roi; Abies Picea, Miller; Picea excelsa, Link; besides many other synonymes.) Leaves less than an inch long, dark green; branches numerous and drooping; hanging cones 5 to 7 inches long. Hardy, and commonly introduced from Europe, where it has a wide range. It is the "White Deal" of the English. There are the following varieties, most of which are in the Park:

Altorferiana, Hoopes. Originated in 1865 in the grounds of Hoopes Bro. \& Thomąs, West Chester, $\mathrm{Pa}$. It is a dense globular dwarf, with crested clusters of sharp-pointed leaves terminating the branchlets. * brevifolia, Cripps; is a pigmy, with minute leaves. Carpatica, Loudon; leaves long and dense. Cephalonica, Parlatore; compact tree, of medium size; leaves flat, rigid, dark green; cones 5 to 6 inches long; erect. This is usually known under the name of Picea Cephalonica, Loudon. I have placed it as a variety under Abies excelsa for the simple reason that Parlatore does so, though I am bound to say that the erect cones and disposition of the secondary branchlets (to say nothing of more important characters) give it a very different appearance. From Mount Enos, in Cephalonia. Handsome and hardy. Clanbrasiliana, Loudon; is a dwarf, compact shrub, produced in Ireland. * denudata, Hort.; with reflexed, spreading branches; leaves stout and appressed. * elegans, Loudon. eremita, Knight; has bark yellowish red; leaves short, reverted, and blunt-pointed. Finedonensis, Paul; the exposed younger leaves are "pale yellow or straw color at first, then bronzy brown, at last light green." inverta, $R$. Smith; has branches drooping as in Weeping Willows; leaves larger and brighter than in the species. mucronata, Loudon; is a French dwarf, with dark-green leaves and rigid crowded branches. monstrosa, Loudon; has branches and branchlets thick and straggling. nigra, Loudon; stout leaves, dark green ; cones large. pendula, Loudon; the leaves are larger "than those of the species;" branches and branchlets drooping. pyramidalis, Hort.; has branches crowded into a complete mass, the outline of which resembles a Lombardy poplar. pygmæa, Loudon; is a foot high, and pressed to the ground. stricta, Loudon; is 3 to 4 feet high, and has erect branches and slender compressed leaves. tenuifolia, Loudon; has thin leaves, slender branches, and few branchlets. variegata, Loudon; has some of the leaves and smaller branches blotched with pale white or yellow, the rest remaining green. Besides the above there are enumerated diffusa glauca, Donetti, conica, and elata.

Abies Fortunei, Lindley. Intermediate Fir. (Pinus Fortunei, Par. latore; Abies Fezoensis, Lindley; Picea Fortunei, Murray.) From China. 60 feet high; leaves $I$ to $I \frac{1}{2}$ inches long, terminating in a sharp, slender point; cones erect, as in Picea.

Abies Menziesii, Loudon. Menzres' Spruce. (Pinus Menziesii, Doug. las; Abies Fezoensis, Siebold and Zuccarini; Picea fezoensis, Carriere.) Tree 60 to 75 feet high; leaves short, stiff, and very sharp-pointed; pendulous cones 3 to 4 inches long. Northwest coast of America; Rocky Mountain region also. Hardy and of rapid growth. (The above name and distribution are not in accordance with Dr. Engelmann's latest determination.)

Abies Mertensiana, Lindley. California Hemlock-Spruce. (Pinus Mertensiana, Bongard; Abies Albertiana, Murray; Picea Mertensiana of the French gardens; Tsuga Mertensiana, Carriere.) Tree 100 feet high, resem- 
bling our II emlock-Spruce, and replacing it on the West coast. Ranges from Sitka and the head of Fraser River south to California. Branchlets hairy; timber soft, but hard to split.

A bies nigra, Poiret. Br.Ack or Dotri.e Spruce. (Pinus nigra, Aiton; Fisea nigra, Link: Abies Mariana, Miller.) In cold situations it is a vigoreus tree, fo feet high. Trunk tall, straight, and with the tranches forming a benutiful slender spire. Foliage short, stiff, rather square, dark green. Colder parts of North America, ranging southward along the mountains. Usually growing near the white or single Spruce. Timler small, lut fair in quality; leaves used in making spruce beer. The variety pumila, K'nighl, is small and compact; only 3 to 4 feet high. There is also another variety, elegans.

Abies obovata, Loudon. Obovate-Coned SrRuce. (Pinus obovata, Antoine.) Altai Mountains, where it reaches 100 feet in height; slender scattered leaves bright green and sharp-pointed; cones egg-shaped.

Abies orientalis, Poiret. Oriental. Spruce. (Pinus orientalis, Linnaus; Picea orientalis, Carriere.) Region of the Black Sea. 75 feet high. Hardy, and presenting a dense mass of foliage.

* A bies Pattoniana, feffrey. Patton's Giant Spruce. (Pinus Paltoniana, Parlatore; Abies gracilis, Hort.; Abies Willinmsonii, Nezuberry; Abies Hookeriana, Murray; Picen Californica, Carriere; 7 suga Hookeriana, Carriere.) Mountains of Northern California, where it grows 100 to 150 feet high certainly, and is by some said to attain a much greater height. Leaves 3 -sided, blunt-puinted; branches and branchlets woolly; ripe cones light brown.

Abies polita, Siebold and Zuccarini. Tiger's-TAIL Spruce, (Pinus

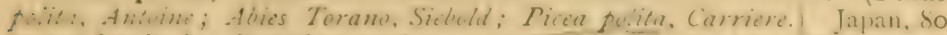
ti. 100 feet high. Branches pendulous; cones 3 to 4 inches long, bright green when young, chestnut brown when older.

* Abies rubra, Poirel. Red or ARctic Spruce Fir. (Pinus mubra, Lambert; Picea rubra, Link; Abies nigra, var. rubra, Michaux.) Much

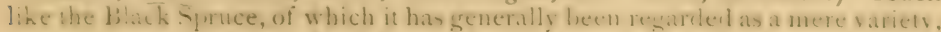
save that the cones are reddish brown and the wood brownish. Northern parts of North America, where it is the last tree to disappear as we approach the pole. Grows 60 to zo feet high. Timber fair in quality. There is alsu a varitty ccerulea, a slender dwarf, 6 or 8 feet high; "fuliage bluish gray; cones violet-colored."

Abies Smithiana, Loudon. "Innian Spruce Fir." (Pinus Smilhiana, Lambert; Abies morinda, Hort. ; Picea morinda, Link.) Eastern and Southeastern Asia, 100 feet or more high, Teaves $2 \frac{1}{2}$ inches long, very sharp-

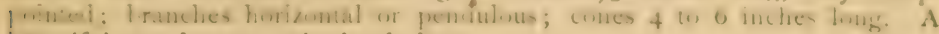
I.c.utiful tree, but not quite hardy here.

Abies Tsuga, Siebold. Japan Hemlock-Srruce. (Pinus Tsuga, Anfoine; Tsuga Sieboldii, Carriere; Abies diversifulia, Horb.) Japan. A

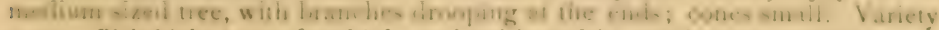
rana, Siebold, is 3 to 4 feet high, and cultivated in pots by the Japranese.

Araucaria. Male and female flowers on different individuals; cone-scales

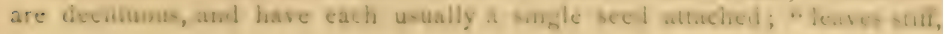


flattened, pointed, and more or less spreading." In other respects the genus essentially resembles the Pines, Firs, etc.

Araucaria imbricata, Pavon. Chim Pine. (Araucaria Chilensis, Mirbel; Abies Arancaria, Poiret; Pinus Araucaria, Molina. There are, besides, other synonymes, the enumeration of which would be out of place here.) Tree from Southern Chili, growing but a little below the snow-line. In Chili it grows 150 feet high. The nuts it produces are over an inch long, and they furnish to the Indians of the region an inexhaustible supply of food. It is even predicted that in England (where it is hardy) it will in time prove of as much value as a source of food as the Spanish chestnut is in Spain. Hardy in the Southern United States, but its hardiness here is very doubtful. The other species of the genus are absolutely tender with us.

Biota. Differs from the Arbor Vita, Thuja (which see), mainly in having no wings to the seeds. There are but two species, which, however, have produced a great number of varieties.

Biota orientalis, Don. ChInese Arbor Vite. (Thuja orientalis, Linnaus; Cupressus Thuja.) From China and Japan, where it grows 20 feet high. Not so desirable for planting here as our own Arbor Vita. The following are its varieties:

Antarctica, - - ? * argentea, Hort.; has silvery-white variegated branchlets. * arthrotaxoides, Hort.; is a close dwarf shrub with muchcontorted branchlets. aurea, Hort.; is the DWARF Golden ARBOR Vite, a globular, dense shrub, never more than 5 feet high, with branchlets in winter yellow or yellowish green. elegantissima, Rollisson; has the tips of all the branches golden yellow in autumn. Gordon calls it the finest of all the varieties. * falcata, Lindley; grows $\mathbf{1 5}$ feet high in Japan, where it is used to form hedges. Takes its name from the falcate or sickle-shaped recurved scales to the cones. This same variety has also produced a dwarf form. filiformis, - ? is on the list of Parsons \& Sons, as furnished to the Park; probably a form of pendula. * funiculata, Hort.; has very slender simple branchlets, which are quite green, and which have small, sharp-pointed leaves. glauca, Pince; this plant appears as if dusted with meal or with silver, from the glaucous powder on the leaves and branchlets. gracilis, Carriere; includes the variety "freneloides of the Belgian gardens." It is a slender, erect, compact form, with small, sharp foliage, and comes from Northern India. intermedia, ?; catalogue of Hoopes Bro. \& Thomas gives this as furnished the Park. Meldensis, Lazuson; resembles a red cedar when young, and is probably a hybrid. * monstrosa, Carriere; has few, short, twisted branches, and thick, blunt-pointed leaves. Nepalensis; is placed by Gordon under gracilis (see above). * Pekinensis, Gordon; a large tree found near Pekin. pyramidalis, Endlicher; is the TAll Chinese ArBor Vite; tall tree, "resembling the upright cypress in shape." semperaurescens, Lemoine; keeps its golden color the year through. * Sieboldii, Endlicher; known to the Chinese as Peacock's Tail, from its close fan-like branchlets and compact general outline. "Cultivated in pots by the Chinese." triangularis, Hort.; is a dwarf variety, with the branches arranged in a triangular instead of a fanshaped manner. variegata, Endlicher; has the branchlets variegated with gold and green. Zuccariniana, Hort.; is a dwarf of globular outline, deep green color, and said "to come true from seed."

Biota pendula, Endlicher. The WeEping Arbor Vite. (Biota orientalis pendula, Parlatore; Cupressus pendula, Thunberg; Thuja pendula, 
Lambert.) " lissh or small tree, with slemiler, drooping liranches and hranch. lets;" the latter sometimes even thread-like, and collected in clusters along the branches. The garden variety flagelliformis belongs to this species. Generally cultivated in China and Japan for its peculiar appearance.

Cedrus. CEDAR. Male and female flowers on same tree: leaves evergreen and many in a cluster; cones smooth, oval, erect, and with the scales separating from the axis; seeds 2 under each cone-scale, containing much turpentine. Fine trees from India or Northern Africa.

Cedrus Atlantica, Manetti. Mount Atlas Cenar, African Cepar. (Pinus Cedrus Allantica, Parlatore; Cedrus Africana, Gordon; Abies Atlantica, Lindley; Pinus Atlantica, Entlicher.) From the mountains of Algiers, where it grows 100 feet high, and has, when old, a flat top. Hardy here under slight protection and in favorable localities.

Cedrus Deodara, Loudon. Deodar or Indian Cedar. (Pinus Deodara, Roxburgh; Abies Deodara, Lindley; Cedrus Indica, De Chambr.) In the Himalayas it grows to a great size. Its success here is very doubtful.

Cedrus Libani, Barretier. Cenar of Lebanon. (Pinus Cedrus, Linnaus; Abies Cedrus, Poiret; Larix Cedrus, Miller.) This historic species is hardy as far north as Philadelphia. It is a magnificent tree, with widespreading horizontal branches, and, in the old trees, a flat top. Apart from its associations, it is worthy a place in every park. It was once supposed to be peculiar w Mount Lelanon, hut is now well known to have a much wider range in North Africa. Among its varieties are argentea, Loudion, which has leaves of a silvery white hue on either side. nana, Loudon; is a dwarf, not exceeding 3 feet in heinht, with short shots and leaves smaller than thone of the species. * pendula, Knight: has slender pendulous branches, which contrast strongly with the horizontal branches of the original species.

Cephalotaxus. Much like the Yews. Male and female flowers on different plants, the female flower with the ovule enclosed in a cup-like organ, 3 or 4 of them being collected into a sort of head; the male clusters are also aggregated into a head.

Cephalotaxus drupacea, Sieheld. Plim-Frtitri) Crimalntixis, ( $c$ phalotaxus Fortunii famina, Carriere; Podocarpus drupacea, Hort. ; Taxus baccala, Thumberg; Taxus Faponica, Hooker.) A compact evergreen, 30 to 40 feet high. From China and Japan. Hardy here, and is an addition to our list of trees.

Cephalotaxus Fortunei, Heoker. FukTixe's CufHumaxts. I Cepha-

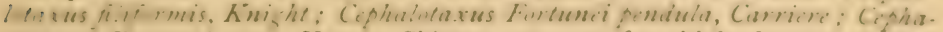
lolaxus Forlunei mas, Horl.) Chinese tree, 40 feet high, having slender drooping branches, and requiring care to make it succeed here.

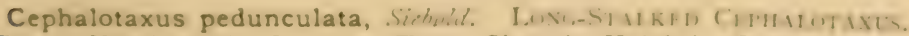
(Taxus Harringlonia, Loudon; Taxus Sinensis, R'night.) Japanese tree, 20 to 25 feet high, with many spreading branches, which often encircle the stem in whorls.

Cryptomeria. A zroup of Chinese and Jajanere trees, with womedy, g!ch. ular cones, the scales of which have divided or fringed edges; male and 
female flowers on the same tree; leaves sharp-pointed, 4 -sided, and somewhat curved.

Cryptomeria elegans, Veitch. Elegant Japan Cedar. (Cryptomeria Faponica elegans, Hort.; Cryptomeria gracilis, Hort.) Large Japanese tree, which will hardly succeed here.

Cryptomeria Japonica, Don. JapAn Cedar. (Cupressus Faponica, Thunberg; Taxodium Faponicum, Brongniart.) From China and Japan, where it grows 50 to 60 feet high. Occasionally hardy here. It has, among others, the following varieties: nana, Forlune; not over 3 feet high, and, as Gordon says, resembling a Juniper. spiralis, Hort.; has the leaves mostly incurved and twisted and placed spirally around the younger shoots.

Cunninghamia. A middle-sized tree from the warmer parts of China, having the sexes on different branches of the same tree. The proper conescales are reduced to mere rudiments; whilst the bracts (outside) are greatly enlarged, sharp-pointed, and toothed, in fact resembling in place and function the true scales. We have here a single species:

Cunninghamia Sinensis, $R$. Brozen. Chinese Cunninghamia. (Cunninghamia lanceolata, Van Houtte; Abies lanceolata, Desfontaines; Pinus lanceolata, Lambert; Araucaria lanceolata, Hort.) Hardy in England, but somewhat doubtful here.

Cupressus. Cypress. A handsome genus of about 17 species, most of which, however, will not stand our climate. It may be characterized thus :Trees and shrubs with fruit composed of hard, shield-shaped scales, which separating at maturity allow the winged seeds to escape; foliage either small, scale-like, and appressed, or larger leaves, which are longer, linear, sharppointed, and opposite.

Cupressus funebris, Endlicher. Weeping or Funeral Cypress. ( $\mathrm{Cu}$ pressus pendula, Hort.) Is from Japan, and in the Park list, but probably too tender for our climate.

Cupressus Lawsoniana, Murray. Lawson's CyPREss. (Chamacyparis Boursierii, Carriere; (hamacyparis Lawsoniana, Parlatore.) A most strikingly handsome tree from Northern California, reaching there a height of Ioo feet. The slender branchlets and bluish-green feathery foliage are peculiarly beautiful. Tolerably hardy here. It has the following varieties : aurea, Waterer; variegated with scattered golden-colored branchlets and leaves. This variety has also produced one (at least) new form. argentea, Hort.; Silver-LeAVED LAwSON'S CYPRESS; has in the younger shuots a decidedly bluish-gray (glaucousi color. compacta, Hoopes; is a compact form originating in the grounds of the late William Reid. erecta, Hort.; is a pyramidal variety, with branchlets of a bright green color. gracilis, Hort.; "a dense hush with beautiful feathery appearance and a deep glossy green color." lutea, Rollisson; has all the smaller branchlets of a conspicuous golden color. nana, Hort.; is not more than 2 feet high; compact in form. and with many small, imbricated, glaucous branchlets; leaves small and ovate. This has also produced a form, argentea, now in the Park. Nicea, — ? ; also appears in the grounds. pendula alba, Paul; has drooping branchlets of a bright silvery hue.

Cupressus macrocarpa, Hartweg. LAmbert's Cypress. (Cupressus Lambertiana, Gordon; Cupressus Reinwardti, Hort.; Cupressus Hartzoegi, 
Cimiere) From California, where it grows bo feet high. It is ammor the finest of the Cypresses. In oulline it is said to resemble a Cedar of Lebanon. Probahily rather tender for this region, though it is considered remainalily hardy in England.

Cupressus Macnabiana, M/uray. MeNin's CyPRFss. (Cupressus glan-

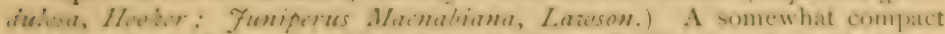
glaucuus shruh, 0 to to feet high, from Northern California. Probably harily here.

Cupressus Nutkaensis, Hooker. NoOtKa Sound Cypress. (Chama. cyparis Nulkaensis, Spack; Thuir excelsa, Bongard; Thuiopsis borealis, Fischer.) A large tree from the Northwest coast of North America. The timber is soft, white, and balsamiferous. Tree has a strong odor. It is among the hardiest of the genus. ${ }^{2}$ Variety variegata, Hort.; is a form of the above having yellowish or whitish branchlets intermixed with the green.

Cupressus sempervirens, Linnaus. Ul'RUiHT CrPRFsis. (Cupressus fasfirtinfa, De Candolle; (upressus stricta, Miller.) A spire-like tree, resembling in outline a Lombardy Poplar. From Greece and Asia Minor. In the Park, but probably too tender to succeed.

Cupressus thyoides, Linneus. White Cedar. (Chamacyparis spharoidea, Spach; Thuja spharoidea, Hort.) Our common White Cedar, which ranges from New England to Wisconsin, and from New Jersey south. Tree 30 to 70 feet high, with a general resemblance to Red Cedar. It has decided claims as an ornamental tree or shrub. Its timber is of very considerable value. Quite hardy. Variety variegata, Endlicher, differs in its yellow branchlets, intermixed with green. Its color and hardiness make it desirable for us.

Cupressus torulosa, Don. Twisted or Bhotan Cypress. (Cupressus Cashmeriana, Hort.; Cupressus Nepalensis, Loudon; Cupressus pendula, Grifuh.) A large tree from India. In the Park list, but regarded by Hoppes as tender.

Juniperus. JUNIPER. Trees, large or small, of considerable importance. Male and female flowers separated, sometimes on different parts of the same tree, at other times on different trees. Fruit a small berry-like body, with usually a strong odor, and enclosing 1 to 3 hard seeds. There are from 30 to 40 species enumerated.

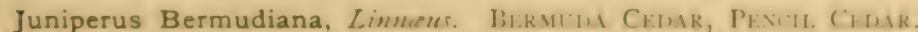

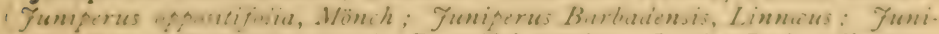
perus Cedrus Bermuda, Ray.) Beautiful species. In the Park collection, but probably too tender for this latitude. Its wood is well known in the common lead. pencils.

Juniperus Chinensis, Linnaus. CHINAs Jivirer. I Funiferui dimer.

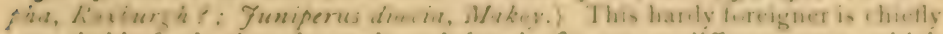
remarkable for having the male and female flowers on different trees, which are very unlike in their appearance.

1 Since the above was written, doubts have been cast on the hardiness of this species here. See Ciardener's Monthly, March, 188u, P. 70. 
Juniperus communis, Linnaus. COMMON JUNIPER. (Funiperus minor, Fuchs.) Tree seldom exceeding 20 feet high. Common to Northern America and the northern parts of Europe and Asia. It is a hardy species, thriving in almost any soil. The natural shaggy habit of the plant may be remedied by binding and trimming. It has the following varieties: Alpina, Linnous; is the dwarf, prostrate form which appears in some books under the name of $\mathrm{Ca}$ nadian Funiper. Its beautiful foliage makes it very effective as an ornamental creeper on rock-works. compressa, Carriere, is a small variety, with a compact, pyramidal head. Cracovia, Loddiges; known as the Cracow Funiper, and is a hardy, straggling bush, which is a native of Poland. Hibernica, Loddiges. IRISH JUNIPER; is a stiff, erect, column-like shrub, beautiful in its proper place, but decidedly the opposite when not in keeping with its surroundings. Usually hardy here. Suecica, Loudon. SWEDISH JunIPER; is rather larger than the Junipers hitherto mentioned, and indeed has produced fair timber. Outline of the tree is conical, owing to the upward tendency of the branches.

* Juniperus conferta, Parlatore. Crowded-Leaved Juniper. ( $F u n i$ perus litioralis, Maximo.) From Japan, and probably hardy here. Differs but slightly from Funiperus rigida; has, however, the "leaves more crowded, grosser, and triangular." Berries are brown-colored.

Juniperus Davurica, Pallas. Davurian Juniper. A low, prostrate shrub from Siberia, with each sex (on different trees) having peculiar leaves.

Juniperus densa, Gordon. Dense or Bushy Indian Juniper. (Funiperus recurva densa, Hort.; Funiperus recurva, Hort.) Has been regarded as a variety of the common Juniper. Hardy shrub, about 6 feet high, with yellowish-green foliage and round, small, 3 -seeded berries. From India at high altitudes, where it is used for incense and for making yeast.

Juniperus drupacea, Labill. Plum-Fruited Juniper. (Arceuthos drupacea, Antoine; Funiperus latifolia arborea, Tournefort; Funiperus major, Bellonius.) This, for a Juniper, is a fair-sized tree, and is perfectly hardy. It is considered by Gordon the finest species of the genus. Native of Syria.

Juniperus excelsa, Bieberstein. Tall Crimean Juniper. (This species has such a host of synonymes that no attempt at enumeration will be made. See Gordon's Pinetum.) From the eastern end of the Mediterranean region, where it grows 30 to 40 feet high; here it is hardly more than a shrub, and is more than likely to be injured by the winter. Though in the Park, it can hardly be considered as an available tree. We have of it the following variety: stricta, Rollisson; is a tall, slender, or narrowly-conical spire, of a silvery glaucous color. Hardy in England; but doubtful here. It also appears in collections as Funiperus stricta, Hort.

* Juniperus flaccida, Schlechtendal. Loose-Growing Juniper. ( funi- $_{\text {- }}$ pernes gracilis, Endlicher; Funiperus fatida faccida, Spach.) Mountains of Mexico, where it becomes 30 feet high. Hoopes advises it here for pot-culture.

Juniperus hemisphæricus, Presl. Globular Juniper, Hedgehog JuniPER. (Funiperus communis hemispharica, Parlatore; Funiperus echinoformis, Kuiz; Funiperus nana hemispharica, Carriere.) A dwarf, globular shrub, only $\mathbf{I}$ to 2 feet in diameter. The thick branches and spreading, sharppointed leaves make the name of Hed gehog Funiper very appropriate for this species. It is perfectly hardy here, though it comes from the barren and parched side of Mount Etna. The variety monstrosa, Hoopes, originated 
on the groumli of Henpes Bro, and Thomas in 1870 . It " has stent, erect branches from every part of the plant, which are of a silvery glaucous color." How hardy or permanent it may be does not yet appear.

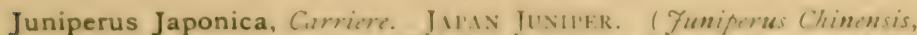

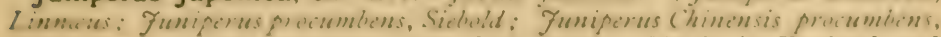
Endlicker.) A low, spreading bush from Japan. Hardy in England, and probably so here. It has the varieties-alba, Standish; from Japan, the smaller branches and branchlets of which are white: commonly known as the White Variegated Japan Juniper. aurea, Fortune, known as the GoLdEN VARIEGATED JAPAN JUNIPER; has the smaller branches and branchlets of a golden-yellow color, and is quite a handsome shrub.

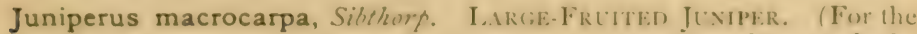
long list of synonymes of this species, Gurdon's Pinetum may be consulted.) A desirable shrub, ro feet high in its Mediterranean home, but not quite hardy here. It is in the Park list, however.

Juniperus nana, Millenone. Under this name Gordon gives what others have considered as a form of the Juniper common to the colder parts of North America. Hardy here, of course.

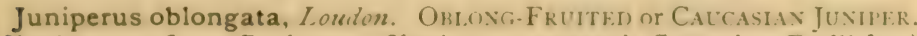
( Funiperus reflexa, Parlatore; Funiperus communis Caucasica, Endlicher.) A hardy bush, 4 to 6 feet high, from the Western Caucasus and the Taurian Mumbains. I.eaves rigid, sharp-pointed, green on one side and glaucous on the other. The branches turn upwards at the ends, but the slender branchlets droop. Handsome, and hardy here.

Juniperus occidentale, Hooker. WEsTFR. JUNIPF, ROCKY MUUNTIN JUNIPER. (List of synonymes too long to quote here: see Gordon's Pinetum for 13 of them.) A middle-sized, beautiful tree, but not hardy here. Engelmann separates. from this Funiperus Californica, Carriere; the latter, lie-liles its structural peculiarities, coming from lower grounds. The l'ark has also the variety Parsonii.

Juniperus Oxycedrus, Linneus. Prickly CedAR. (Funiperus Monspeliensium, Lobel; Funiperus Uxycedrus Phanicea, Dodon.) Shrub or small tree from the Mediterranean shores. The fruit is large for a Juniper, and is used for flavoring gin. In the Park; but its hardiness is doubtful.

* Juniperus pachyphlae, Torrey. Thick-Barked Juniper. This striking tree from Arizuna and New Mexico might be worth a careful trial liere. In its home it grows on cold, exposed, often barren situations, and this suggests a trial of it here. It has a thick white bark, strikingly like that of White Oak at a distance.

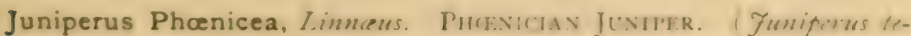
Iragona, Mönch; Funiperus Langoldiana, Hort.; Cupressus Devoniana, Hort.) Small tree from the South of Europe, requiring here great care and a warm situation to make it succeed. In outline it is a beautiful pyramid. The Park also has the variety Lycia, London; from the South of Europe. It is quite as handsome as the species, but no hardier. From this iree the olihanum "used as incense in religious ceremonies on the Coutinent" is ubtained. It is also the Cypress-Leaved Cedar of the Greeks.

Juniperus pseudo-Sabina, Fiscker. SIHerian Juniper. A dence spreading bush, 3 to 4 feet high; from Siberia. It is not certain that it will 
succeed here, but from its cold home we might infer that it would endure our winters. Leaves are different in shape on different parts of the shrub.

Juniperus prostrata, Persoon. Prostrate Juniper. ( Funiperus Sabina, Linnaus.) A creeping shrub, ranging from the Lakes to Northwest America. Hardy. Beautiful ornament to rockeries, a vigorous grower, and of a darkgreen color. Sometimes spreading over 30 feet in circumference when it is not more than 3 feet high.

Juniperus recurva, Don. Recurved-Branched Juniper. (Funiperus incana, Hamilton; Funiperus repanda, Hort.) The sexes of this plant are on different trees, which differ widely in appearance. The rough bark scales off. Old leaves are chaffy, and these, with the peculiar bark, serve at once to indicate the tree. In India (its home) the berries are burned as incense. In some places it becomes a large tree, in others remains a mere shrub. It is rather tender here.

Juniperus rigida, Siebold. Stiff-Leaved JAPAn Juniper. ( $F$ uniperus communis, Thunberg.) From China and Japan, where it grows 25 feet high. Handsome, but requiring care and protection here.

Juniperus Sabina, Linnaus. SAvin Juniper. ( Funiperus cupressifolia, Hort.; Juniperus Lusitanica, Miller; Funiperus Lycia, Pallas.) Common to the mountains of Europe and to the colder parts of North America. With us it is usually prostrate; in Europe it rises 6 to 7 feet high. Rather too rugged for ornament, though its hardiness commends it. Used as a remedy. It has the following varieties: cupressifolia, Aiton (not recognized by Gordon); has leaves of a "silvery glaucous hue." nana, Hort; ; is a dwarf carpet Juniper; rather out of place with us. tamariscifolia, Aiton; TAMARISKLeAved SAvin. variegata, Loudon; has white, lemon-colored, and dark leaves intermixed on the same shrub.

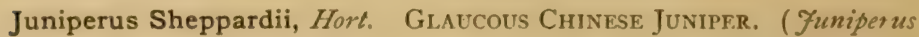
spharica glauca, Forlune; Funiperus sp. North of China in catalogues?) There appears to be really much doubt as to the true relations of this small tree. Gordon positively asserts it is different from $\mathcal{F}$. sphcerica. The foliage is so brightly glaucous as to render the tree conspicuous even at a distance. From the North of China.

Juniperus sphærica, Lindley. Globular-Fruited Juniper. ( funi- $^{-}$ perus Fortunei, Van Houtle; Funiperus Chinensis Smithii, Loudon.) A handsome tree from Northern China, where it grows 30 to 40 feet high. Its beauty makes it a desirable acquisition to our parks, but its hardiness is rather doubtful.

Juniperus squamata, Don. Scaly-Leaved Nepal Juniper. ( $\mathcal{F}_{\text {uni- }}$ perus recurva, Hamilton; var. squamata, Parlatore; Juniperus dumosa, Wallich; Funiperus Lambertiana, Wallich; Funiperus rigida, Wallich.) This is a handsome trailing species, which does well on rockeries. It comes from Nepal and Cashmere. Spirituous liquor is made from the berries. The branchets also are used in preparing yeast and also in preparing "arrach" from rice.

Juniperus taxifolia, Hooker. YeW-LeAved Juniper. (Funiperis oblonga pendula, Loudon; Funiperus pendula vera, Hort.; funiperus communis pendula, Hort.) Shrub with spreading branches which have pendulous ends; 
the hampoineet leaves are the green below and glanceus or silvery above. Island of Loo-Choo anil the North of China.

Juniperus tetragona, sititechindat. Is a low, much-branched thrub in the Park. It comes from the mountains of Mexico, and its entire hardiness remains to be proven.

Juniperus thurifera, Limneres. Spanish Juniper. (Cedrus Hispanica, Tournefort; Guniperws Hispanica, Miller.) Tree from Spain and Portugal, 30 to 40 feet high, forming in outline a close cone, with the tips of the branches curved upwards and inwards; berries large and dark. Growth here is somewhat precarious.

Juniperus Virginiana, Linnaus. Virginian Red Cedar, Red Cedar. (Funiperus arborescens, Mönch; Funiperus Caroliniana, Hort) Native to the entire eastern coast of the United States; 30 to 40 feet high; regular but variable in oulline,-i.e, branches erect or pendulous; shape of head spirelike or globular. Hardy in cultivation. We have also the varieties-Barbadensis, King Islands; also known as $\mathcal{F}$. Bedfordiana. * Caroliniana, Loddiges; upright; berries very small, and violet when ripe. * dumosa, Carriere; is a bushy variety which Hoopes does not regard as of sufficient interest to cultivate. glauca, Hort.; is distinguished from the species only by the leaves being of a "glaucous white color." humilis, Hort.; is a dwarf, branching form which hecomes a dense mass 2 to 3 feet high. pendula, Hort.; WEEPING RED CEDAR; of which there are 3 forms,-i.e., the "male, with shorter and more numerous branchlets; the female, with longer, more slender, ancl fewer branchlets;" and the third variety, of a light glossy green, and the handsomest of the three. alba variegata, Hort.; has whitish leaves and branchlets along with the green ones. aurea variegata, Hort.; some golden-colored branchles alpen with the green ones. "Triomphe d'Angers" (?). Waukegan, Meehan (?) Dwarf Red Cedak.

Larix. I.ARcir. Male and female flowers in separate clusters, but on the same tree; leaves deciduous, single or in handsome clusters, which terminate in scaly round buds; cones small, often red when young.

Larix Americana, Michaux. American Larch, Hackmatack. (Abies microcarpa, Lindley: Pinus microcarpa, Lambert; Pinus Larix rubra, Marshall.) A valuable timber-tree, ranging from Canada to Virginia, but most common in the cooler parts. It grows, in the most favorable locations, 75 feet high and 2 feet in diameter.

Larix Europara, De Candolle. European Larch, (Pinus Larix, Linnueus; Abies Larix, Lamarck; Larix excelsa, Link.) A strikingly handsome tree; hardy, and of rapid growth; cones longer than those of the American Larch. Promises to be inportant here in tree-culture for economic purposes. There are the following varieties: "alba, Enillicher; WHTE-F LoWERED Elropeas Larch. glauca, - ? " pendula, Loudon; Guinsald's WhePRAs LARCH; has hanging branches. "repens, Loudon; wide-spreading and hanging branches. rubra, Endlicher; has red flowers.

Larix Dahurica, Turczaninono. Dahurian Larch. (Latix Europera Dahurica, Losdon; Larix Gmelini, Ledebour; Pinsus Dahurica, Fischer.) A dwarf shrub from the cold mountains of Nurthern Siberia. 
Larix Griffithii, Hooker. Siккім LARCH. Abies Griffithiana, Lindley, Larix Sikkimensis, Hooker.) From the higher parts of Bhotan, Sikkim, and Nepal. 30 to 60 feet high. It is said to be an "inelegant species;" in other words, not ornamental.

* Larix Kamtschatica, Carriere. Kamtschatka Larch. (Pinus Kamtschatica, Endlicher; Abies Kamtschatica, Ruprecht; Abies Sibirica, Fischer.) A middle-sized tree from the Kamtschatka region, which would doubtless prove hardy here.

* Larix Ledebourii, Ruprecht. Altainn Larch. (Pinus Ledebonrii, Endlicher, and many other,synonymes.) A large tree from the Altai Mountains of Siberia; bears some resemblance to the European Larch. Cones, however, are very smail.

Larix Lyallii, Parlatore. Lyall's Larch. (Pinus Lyallii, Parlatore.) A middle-sized tree from Northwest America, in the Cascade region. Its most striking peculiarity is the woolly covering of the leaf-buds and young shoots.

Larix leptolepis, Siebold. Slender-Scaled Japan Larch. (Pinus leptolepis, Endlicher; Pinus Larix, Thunberg; Larix faponica, Carriere.) A slender tree, 40 feet high, from Japan, where it is much prized and is called Money Pine.

Libocedrus. A genus quite near to Thuja (Arbor Vita), differing chiefly in having the scales of the cones joined edge to edge, and each scale having but one unequally-winged seed.

Libocedrus decurrens, Torrey. Decurrent-Leaved Arbor Vite. (Libocedrus gigantea, Low; Thuja gigantea, Hort.; but not of Nuttall.) Tall tree from the Sierras of California, making superb lumber. Leaves are decurrent along the branchlets. Called WHITE CEDAR by the Californians. Not hardy here, but in the Park catalogues.

Picea. FIRs. Leaves somewhat 2-ranked; cones erect at maturity, and the scales falling away from the axis.

Picea amabilis, Lindley. Wfastern Silver FIR. (This tree is involved in so much doubt that I give no synonymes.) Dr. Engelmann regards the tree cultivated in Edinburgh under this name as the one so named by Douglas, but he considers it as merely a variety of GRANDIS, to which (variety) he gives the name of DENSIFOLIA, and describes it thus : foliage dense, clustered on upper side of branches, like that of Nordmanniana; leaves dark glossy green above, with two very conspicuous white bands below. Large tree from Oregon and British Columbia.

Picea Apollinis, Rauch. A pollo Silver FIr. (Finus Cephalonica Apollinis, Gordon, in first edition of Pinetum; Abies Apollinis, Link; Abies pectinata Apollinis, Endlicher.) Tree 60 to 70 feet high; head spreading; smooth yellowish bark without the resin-blisters so characteristic of the Silver Firs. Native of Greece.

Picea balsamea, Loudon. Balm of Gilead Fir. (Pinus balsamea, Linneus; Abies balsamifera, Michaux, in part; Abies balsamea, Miller.) Eastern and colder parts of North America, extending southward along the mountains; 60 to 70 feet high. Handsome when young. Wood of no great 
value. The l'ark has the following varieties: Iongifolia, Joudin: with longer leaves and more erect hranches than the species. variegata, hing ht fulinge somewhat variegated with white.

Picea bracteata, Losion. Leafy-Bracted Silver Fir。 (Pinus bracfeufu, Don; Abies bracteata, Hooker.) A large, beautiful tree from California, with linear-lanceolate, acute, hard leaves. Its hardiness is more than duubtful here.

Picea Cephalonica, Intoden. We have doultfully placed this (after Parlatore) under the head of Abies excelsa.

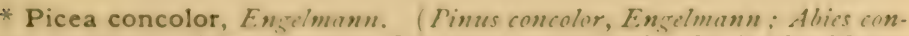
color, Lindley.) Often mistaken for Abies grandis ("by the Rocky Mountain botanists"), which, however, is confined to California (and the region to the north), where both are found. It is "a stately tree," with foliage I io 3 inches lomz and at first pale glaucous, then dull green. It extends into Southern Arizona.

Picea Cilicia, Rauch. Cilician Silver Fir. (Pinus Cilicia, Carriere; Picea Pichea alba, Horl.; Picea longifolia, Hort.) A tall, handsome tree, 50 feet high, growing in the mountains of Asia Minor along with the Ceclar of Lebanon.

Picea firma, Gordon. Japan Silver Fir. (Pinus firma, Antoine; Abies firma. Sicheld and Zucarini: Alies bifida, Sichold and Zucarini.) Leaves solitary, thichiy placel, sharp, blunt-pointed or even notched at the end. Tall tree from Japan. Hardy here.

Picea Fraseri, Loudon. Fraser's Srlver Fir. (Pinus Fraseri, Pursh; Abies Fraseri, Lindley; Abies balsamea $\beta$ Fraseri, Spach.) A small tree from the mountains of North Carolina, "rarely as much as 30 or 40 feet high;" often "mistaken for Picea balsamea, from which it is distinguished by its shorter, denser, and more erect foliage, as well as by the very compact shape and numerous small branchlets."-Hoopes. Picea Hudsonia " of the gardens, often considered as a form of Fraseri, is a sterile dwarf form of [Picea] balsamea."-Engelmann.

Picea grandis, Loudon. Great California Srlver Fir. Pinusgrandis, Douglas; Abies grandis, Engelmann.) A large, valuable timber-tree, attaining in California and the region to the north a height of 240 feet. "Leaves glossy green, I to 2 inches long; cones 2 to 4 inches long, scales twice as broad as high."-Engelmann. Tree not well known. Thoroughly hardy here. I omit the garden varieties Llaviana and lasiocarpa here, as neither appears as such in the last edition of Gordinis Pinctum, anil, further, looth are relegated to what we have named Picea concolor.

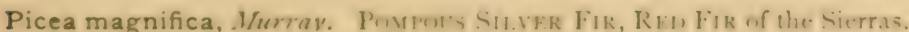
("Abies nobilis, var, robusta, in Hort., Dickson and Tiurnbull; Abies cam. fylocarpa, Murray; Abies amabilis of the California botanists; Psesdolsuga mumibs. .M/Nisb."-Engelmann. California tree, 10 feet in dimeter, an! over 200 feet high.

Picea nobilis, Losdon. Nomtre SILver FIR, RED FIr of the Cascades. (Pinus nobilis, Douglas; Pseudolsuga nobilis, Bertrand; Abies nobilis, Lindlev.) Tree from Oregon, 200 feet high. Foliage rigid glaucous. Hardy here. The variety glauca has the leaves "silvery-white color." 
Picea Nordmanniana, Loudon. Nordmann's Silvfr Fir. (Pinus Abies, Du Koi, in part; Abies Nordmannia, Link; Picea pectinata leioclada, Hort.) Tree common in Black Sea region at a considerable elevation. Grows roo feet high. Timber of good quality. Hardy here.

Picea pectinata, Loudon. Common European Silver Fir. (Pinus Abies, Du Roi; Parlatore, in part ; Abies taxifolia, Desfontaines; Abies Picea, Lindley; Abies pectinata, De Candolle; Pinus Abies pectinata, Lamarck.) This well-known tree, so common in the Alps, is found also extensively diffused over Europe, except on the northern mountains. Cultivation has produced the following varieties: * fastigiata, Booth; leaves small, branches erect, slender, compressed, resembling a Lombardy Poplar in outline. Originated at Metz. * pyramidalis, Hort.; somewhat like the preceding, save that the ends of the branches droop slightly; of German origin. * nana, Knight; slow, couple of feet high; produced in France. pendula, Godfrey; has the branches and branchlets all drooping; is of French origin. * tortuosa, Booth; is a German variety, with branches and branchlets much twisted. variegata, Hort.; has straw-colored and green leaves variously intermixed.

Picea Pichta, Loudon. Pitch Silver Fir, Siberian Silver Fir. (Pinus Sibirica, Turcz.; Abies Sibirica, Ledebour; Picea Sibirica, Hort.) Leaves dark green above, somewhat lighter on under surface, I inch long. From the mountains of Central Asia. Not more than 50 feet high, and with dense head. Perfectly hardy here. Well suited for ornamental planting.

Picea Pindrow, Loudon. Upright Indian Silver Fir. (Pinus Pindrow, Royle; Abies Pindrow, Spach; Abies Webbiana affinis, Hort.; Picea Herbertiana, Madden; Taxus Lambertiana, Wallich.) Tree from the mountains of India at an elevation of several thousand feet above the sea; branches flat, horizontal, and in whorls (circles around the stem). Its dark foliage produces a most gloomy forest. From 80 to 125 feet high. Timber second-rate. In the Park; but its hardiness here is very doubtful.

Picea Pinsapo, Loudon. Pinsapo Fir. (Pinus Pinsapo, Boissier; Abies Pinsapo, Boissier.) Tree 60 to 70 feet high, from the mountains of Southern Spain and Northern Africa. Leaves $1 / 2$ inch long, sharp or obtuse. Hardy here. The variety variegata, Hort., has "some of the leaves and smaller shoots straw-colored and intermixed with the green ones."

Picea Veitchii, Hort. VeItch's Silver Fir. (Pinus selenolepis, Parlatore; Abies Veilchii, Lindley.) Tree from 100 to 135 feet high. From the sacred mountain of Fusi-Yama, Japan.

Picea Webbiana, Loudon. WebB's Indian FIR. (Pinus Webbiana, Wallich, MSS:; Abies Wibbiana, Lindley; Abies spectabilis, Spach.) Tree 70 to 80 feet high. From the higher mountains of India. A tender but very striking tree, with purple cones 5 to 7 inches long which furnish a violet-colored dye.

Pinus. The PINes Proper. Male and female flowers in different clusters on the same tree; the former (male) in scaly clusters, the latter (female) becoming a woody cone, under the scales of which the usually winged seeds are found. Leaves in clusters of 2,3 , or 5 (in a single instance $\mathbf{I}$ ) which are surrounded at base by a more or less conspicuous dry thin sheath.

Pinus Austriaca, Höss. Austrian Pine. (Pinus Laricio nigricans, Parlatore; Pinus nigra, Link; Pinus Laricio Austriaca, Endlicher; Pinus 
nigrescens, Hort.) A native of Southern Central Europe, where it grows 120 feet high. Timber valuable. Hardy here, and advised by $\mathrm{H}$ (sopes for hedges destined to afford protection to stock or tencier plants. It has a dense symmetrical form, and the oblong cones shine as if varnished. It is, unfortunately, attacked in the leaves by some as yet unknown fungus which causes them to turn yellow. The variety variegata, Lawoson, has green and straw-colored leaves on the same branchlets.

* Pinus aristata, Engelmann. Awn-Coned PINE. A characteristic tree of the alpine summits of the Rocky Mountains, where it grows from 9000 feet above the sea-level upwards, nearly or quite to the limit of tree-growth. Its increase in size appears to be extrenely slow. The leaves are remarkably persistent, and have been known to remain on the tree at least 16 years. The tree probably attains an age of from 600 to 900 years.

Pinus Ayacahuite, Ehrenberg. Ayacahuite PINE. (Pinus strobiliformis, Enselmann. There are a number of other unimportant synonymes.) This species is a native of Mexicu, especially of the southern parts, at from 7000 to 8500 feet above the sea-level. It bears a striking likeness to the Cummon White Pine, and grows in its home 100 feet high.

* Pinus Banksiana, Lambert. Banks, Gray, or Northern Pine, Scrub I'INe. (Pinus Hudsonica, Poirct; Pinus rupestris, Michaux.) Native of the northern parts of the United States, thence as far north as Hudson Bay. Rather small in size, not exceeding 40 feet in height. Timber is said to be light and tough. Consiciered quite ornamental in England, though in its native haunts it is unsymmetrical and straggling.

* Pinus Brutia, Tenore. Calabrian Cluster Pine. (Pinus Pyrenaica, Lapeyrouse, in part: Pinus Loiseleuriana, Carriere. We have adopted the above name-i.e., Brutia-un grounds of expediency alone: see P. Pyrenaica of this Catalogue.) Tree 70 feet high, from the mountains of Calabria; branches spreading; leaves bright green, and timber said to be good. Hardy here, so that on grounds of utility as well as of ornament it is entitled to culture with us.

Pinus Bungeana, Zuccarini. Chinese Lace-Bark Tree. (Pinus excorticaln, Gordon.) Tree from Northern China. Not large-sized; leaves short and stiff. Coming from a cold and desolate region, it does well here. The outer bark is shed each season: hence the nearly vertical branches have a white color, which produces a most striking effect.

Pinus Cembra, Linnaus. Swiss Stone PINe. Long ago introducerl into cultivation from the higher regions of the Alps, where it forms conspic. uous forests. The wood is soft and fine-grained, and much used in carving. Considerable quantities of resin are also derived from it. Hardy, and grows well in even poor soil. The Park has the following varieties: Sibirica, Loudon; is the Siberian Stone PINe; found in Eastern Siberia, where the large seeds are eaten. pygmza, Fischer; is from the more barren parts of Eastern silneria, and hardly more than 3 feet high, but with spreading branches "sumetimes 12 feet long and 3 inches in diameter."

Pinus cembroides. There is much confusion regarding the use of this name. See Pinus edulis, Engrelmann, of this list.

Pinus contorta, Dougrles. Twistes)-Brasch PINe. (Pinus Boursieri, Carriere.) Iree of the Rocky Mountains and of the Western cuast from 
Central California northward. Along shore it protects the other vegetation, though it is never large and hardly ever symmetrical in its growth. In British Culumbia the Indians eat the tender inside bark in early spring. Hardy.

Pinus densiflora, Siebold and Zuccarini. Dense-Flowered Japan Pine. (Pinus Faponica, Antoine; Pinus rubra, Siebold, in part.) From Japan, where it grows about 40 feet high. Timber of fair quality. The resin is in general use in Japan for healing wounds. Hardy.

Pinus edulis, Engelmann. Nut Pine, Piñon Pine. This has been regarded as a form of Pinus cembroides, Zuccarini, from which it appears to be distinct, and it has also been confounded with Pinus monophyllos, Torrey and Fremont, the larger nuts of which are edible. It is a low scrubby tree which is rich in resin. It is common in Southern Colorado, Arizona, and New Mexico. Hardy, but the timber contains much resin, and is of little value save as fuel. Nuts also edible.

Pinus Elliottii, Engelmann. ElliotT's PINE. From South Carolina, and reaching south to Georgia and Florida. A handsome tree, which, as it is hardy in the southern part of this State, is worthy of a trial in protected situations here.

Pinus excelsa, Wallich. Lofty Bhotan Pine. (Pinus Dicksonii, Hort.; Pinus pendula, Griffith; Pinus Indica, Manetti.) Native of India, especially on the higher grounds, where at an altitude of from 6000 to 10,000 feet it appears to be common and to reach an altitude of 150 feet. Timber good, compact yet soft, white, and yielding a fragrant resinous turpentine. The drooping branches have given it the name of DROOPING FIR. Desirable tree in parks. Hardy here.

Pinus flexilis, Fames. American Cembran Pine, Flexible-Branched Pine, Rocky Mountain White Pine. (Pinus albicaulis, Engelmann; Pinus Shasta, Carriere.) A middle-sized tree, native of Colorado, New Mexico, Arizona, and Southern California. Quite valuable, and of slow growth, but handsome in shape. The flexibility of the branches is said to be due to the thick elastic bark covering them.

Pinus Gerardiana, Wallich. Gerard's Pine. (Pinus Neosa, Govan.) Tree 50 feet high, from the Thibet region, where it ranges to an altitude of I2,500 feet above the sea-level. It is called by the Orientals the Sweet Nut Pine, from its edible nuts. It secretes resin in large quantities. The tree is reasonably hardy here.

Pinus insignis, Douglas. Oregon Pitch-Pine. (Pinus Californica, Loisel.) One of the most beautiful of the West Coast Pines. It branches from the ground up. Hardy in England, but not likely to be so here, though it is in the Park collection.

Pinus inops, Solander. Jersey or Scrub Pine. (Pinus Virginiana, Mill. Dict.; Pinus variabilis, Pursh.) A low branching tree, of no special value except as fuel. It grows in poor and sandy soil from New Jersey to Kentucky and southward. Hardy enough, but not very ornamental in parks or other public grounds.

Pinus Koraiensis, Siebold and Zuccarini. Corean PINE. (Pinus Strobus, Thumberg. The tree so named by Linnæus is our common White Pine.) It is 30 to 40 feet high, and cultivated in China and Japan. Native of the cold 
shores farther north on the peninsula of Coren, where the seeds are eaten and the tree is known as the SEA-SHORE or MARITIME PINE. Hardy here.

Pinus Laricio, Poiret. Corsican Pine. (Pinus altissima, Banks; Pinus Corsicana, Hort.) A tall, handsome tree, 80 to 130 feet high, from the Mediterranean region. It is rapid growing and short-lived. Timber is longgrained, white, and said to be easily worked and valuable. Hardy and attractive in our region. The Park has the varieties-Caramanica, Loudon; tree smaller, head rounder and more bushy, than the species. Leaves very dark green, and the slender hranches with red bark. Calabrica, Delamarre; "has branches densely clothed with leaves which are longer than those of the ordinary form." Hardy and desirable. pygmæa, Rauch; is a dwarf mountain form, with branches lying flat on the ground, and with leaves short, rigid, and slightly curved. The other varieties hardly merit notice here.

Pinus Lambertiana, Douglas. Sugar Pine, Lambert's Pine, Giant PINE. (The distinct character of this tree has, fortunately, kept it clear of that curse of modern botany,-i.e., synonymes.) The most beautiful tree of the California mountain region. It attains a height of 200 feet and upwards, with a corresponding diameter at base. Its general outline is that of our White Pine. The lumber is of great value, being soft, straight-grained, light, and durable. The cones are often 14 inches long and 5 inches through. The edible seeds are either used fresh or prepared in cakes for winter use. The tree is harcly here, and of rapid growth.

Pinus Massoniana, Lambert. Chinese Pine. (Pinus Sinensis, Lambert; Pinus sylvestris, Lour.? not of Linnaus.) A medium-sized tree from China. It appears to be hardy here. Branches somewhat drooping. Of no great value.

Pinus mitis, Michaux. Yellow Pine, Short-Leaved Yellow Pine. (Pinus variabilis, Michaux the younger.) Native tree, once common over the eastern and southern portions of the country, but now becoming very scarce in the New England States. Timber is valuable especially for ship-building purposes. Once much used here for flooring. Tree when cared for in open grounds becomes quite handsome.

Pinus monticola, Douglas. Mountain Pine. (Pinus Strobus monticola, Aistall.) Tree from Northern California and Oregon; resembling in appearance and in size our White Pine. Timber like the White Pine, but said to be more tough. Hardy.

Pinus Mugho, Bauhin. Mugho Pine. (Pinus montana, Du Roi? Pinus sylvestris Mugho, Baukin.) A hardy dwarf Pine from the mountains of Central Europe, of no special value as a timber-tree; wood red. It has produced the following varieties: nana, Loudon; a dwarf not more than 3 feet high, from the Styrian Alps. rostrata, Antoine; 30 feet high, but with large branches spreading over the ground. Wood is resinous and durable. rotundata, Link; is a small tree with a straight stem. From the Tyrol.

Pinus parviflora, Siebold. Small-Flowered Japan Pine. (Pinus CemBra, Thunberg, but not of Linnaws.) Is a small tree from the colder islands of Japan, on high places. Also cultivated in the islands of Japan. Hardy here.

Pinus pungens, Michaux. Table Mountain Pine. A middle-sized tree, ranging alung the mountains from Georgia to P'ennsylvania. The most char- 
acteristic feature of this species is the stout, sharp, and somewhat recurved prickles which terminate the scales of the ovate cones. The cones remain on the tree a long time, and confer upon it a peculiar appearance from the whorls or clusters, which are 60 striking. The tree is of but little value,- too small for timber, and not rich in turpentine; not even a handsome tree, but still one which commends itself as a species for the Park because of its hardiness.

Pinus Pyrenaica, Lapeyrouse, in part. Pyrenean Pine. (Pinus Laricio, var. tenuifolia, Parlatore; Pinus Hispanica, Cook. I have adopted the name $P$. Pyrenaica solely on grounds of expediency. See Pinus Brutia of this Catalogue.) Tree 60 to 80 feet high, from mountains of Spain and of France. Beautifully conical in outline, attractive in both bark and foliage, and hardy, it should form one of the chief evergreen ornaments of our Park. Timber white and with but little turpentine.

Pinus resinosa, Aiton. RED PINE. (Pinus rubra, Michaux the younger.) An indigenous tree, 50 to 80 feet high, ranging from "Massachusetts to Pennsylvania, and Wisconsin and northward." Bark smoothish; red wood solid, " not very resinous," and valuable. The tree may fairly be regarded as ornamental.

Pinus rigida, Miller. PITCH PINE, SAP PINE. (Pinus tada rigida, Aiton; Pinus lraseri, Loddiges; Pinus Loddigesii, Loudon.) Tree is of middle size, native to, and common in, the Middle States. Hardy. Ornamental, owing to its irregular outline and open growth. Timber is knotty and often too full of sap. Tar may be made in small quantity from it.

Pinus Strobus, Linnaus. White Pine, Weymouth Pine. This tree may fairly be called the glory of our forests. It ranges from Vermont to Virginia, and alung the northern border, where it is most common, west to the Mississippi. It is of rapid growth, and hence desirable either in parks or in forests, attaining sometimes in 20 years a diameter of 2 feet. It grows in its native forests from 125 to 165 feet high, and frequently is 6 feet through. It is so valuable that unless prompt means be taken to preserve or plant it, its practical extermination is near at hand. There are in cultivation the following varieties: * brevifolia, Booth; with the leaves short, numerous, and compressed around the shoots. nana, Knight; from I to 3 feet high, with very slender leaves. * nivea, Knight; leaves erect, dense, dark green when mature, but white on upper surface when young. There are other less important varieties.

Pinus sylvestris, Linnaus, Scotch Fir, Scotch Pine. (Pinus Genevensis, Bauhin; Pinus Rigensis, Fischer; Pinus uncinata, Don.) Native of Northern and Central Europe. Grows from 60 to 100 feet high. It makes up the bulk of the Norwegian pine forests, and is of great commercial value. "It is the Red and Yellow Deal of England." It produces much turpentine, and will grow in nearly any soil, being besides quite hardy and ornamental. From it there are the following varieties: * Altaica, Ledebour; is a compact tree, with short, stiff leaves. * argentea, Stevens; has cones and leaves of silvery culor. * horizontalis, Don; has the branches spreading in a horizontal direction. * latifolia, Gordon; is a robust, rapid-growing form, with larger leaves than the original tree. * monophylla, Hodgins; leaves 2 or 3 in a cluster, but twisted to resemble a single leaf. * nana, Hort.; is one to two feet high, but spreading over the ground; "leaves and branches stunted." * variegata, Hort.; has some straw-colored mixed with the green leaves. 
Pinus treda, Limnaus. Loblorly or Oldfield Pine, Torch Pine, Frankincense. Pine. (Pinus Virginiana lenuifolia, Plukenet.) Tree ranging from Delaware southward along the coast, sometimes under favorable conditions becoming roo feet high. It takes complete possession of worn-out fields in the Suuthern States, so that nothing else will grow on them. This species is not rich in turpentine, neither is the timber of first-rate quality. It does, however, answer for fuel.

The above list includes (along with some which are not thoroughly hardy) most of the desirable Pines for the Park. Many familiar names, especially those of Western species, will be missed. It is to be remembered, however, that many of these fail to stand our winters, and notably so those from the Pacific coast.

Podocarpus. The most striking peculiarity of this large genus is the long peduncle which supports the succulent fruit. Male and female flowers are usually on different trees.

Podocarpus Andina, Pöppig. Plum Fir, Andes Podocarpus. (Podocarpus spicata, Pöppig; Ilaxus spicata, Dombey; Prumnopitys elegans, Philippi.) Tree from the Andes of South Chili, 40 to 50 feet high. Probably hardy here.

Podocarpus Japonica, Siebold. Japan Podocarpus. (Podocarpus lanccolala, Horl.) Is a small tree which is quite common in Japan. Leaves 4 to 8 inches long and $1 / 2$ inch wide; thick, stiff, and blunt-pointed. Hardy here.

Pseudo-Larix. Differs from the ordinary species of Larix (Larches) chiefly in having deciduous scales to the cones. There is but a single species:

Pseudo-Larix Kaempferi, Gordon. Golden Larch, Chinese Larch. (Larix Kaempferi, Fortune; Abies Kaempferi, Lindley; Pinus Kaempferi, Lambert.) Tree from China, 130 feet high; cone-scales widely diverging; cones 3 inches long. May be considered as hardy.

Retinospora. This name is used simply because it is so generally accepted in garden literature; and it is not to be regarded as indicating a genus in a strictly botanical sense. The plants composing it really belong to Cupressus or to Chamecyparis, from which they are distinguished mainly by the resin in the seed-coats.

Retinospora ericoides, Zuccarini. HeAth-Like Retinospora. (Chamacyparis ericoides, Carriere ; Cupressus ericoides, Hort.; Funiperus ericoides, Horl.) Low shrub from Japan. Fairly hardy here. The Japanese cultivate it in pots. The whole plant becomes dingy red as cold weather approaches.

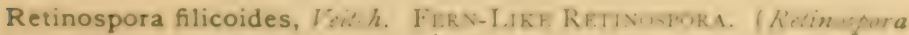
obrusa filicoides, Hort.) Is a handsome, free-growing tree found in Japanese gardens.

Retinospora filifera, Stondish. Thready Japan Cypress. Tree 50 feet high; from Japan, where it is much cultivated for ornament. The varieties aurea and pendula are likewise much cultivated there. grasilis, Visch; is a recent importation, with very slender shoots. variegata, /loopes; is " an 
elegantly-marked form, the young branchlets and leaves being conspicuously tinted with golden yellow."

Retinospora leptoclada, Zuccarini. Slender or Flat-Branchleted RETINOSPORA. (Retinospora squarrosa leftoclada, Siebold; Chamacyparis squarrosa leptoclada, Endlicher.) A large bush from Japan, and much cultivated there. The foliage is of a bright glaucous-green color, closely arranged on the numerous little branchlets, making a compact mass.

Retinospora lycopodioides, Standish. Ciub Moss-Like Retinospora. (Retinospora monstrosa, Hort.) Tree from Japan. Leaves arranged all around the branches, and either sharp-pointed or scale-like. Hence, from the general resemblance to the Club Moss, its common name.

Retinospora obtusa, Siebold. Obtuse-Leaved Japan Retinospora. (Chamacyparis obtusa, Endlicher; Chamepeuce obtusa, Zuccarini; Retinospora Fusinoka, Zuccarini.) A lofty tree, forming the greater part of the forests in the mountains of Nippon, Japan. The timber, owing to its whiteness and compactness, takes a polish and lustre almost like silk, says Gordon. In consequence it is used by the Japanese in erecting temples and in making sacred utensils. Hardy here, but requiring some shade to bring out the full beauty of its leaves. There are the following distinct varieties: argentea, Fortune; which has some of the leaves and branchlets silvery white, contrasting with the green. aurea, Fortune; has golden-colored spray and leaves which contrast well with the green. Of this variety there are other forms. compacta, Hoopes; is dwarfish, with a regular conical outline and fan-shaped branchlets termınating the branches; a well-marked variety. gracilis, Hoopes; produced by Messrs. Otto \& Achelis, of West Chester, $\mathrm{Pa}$.; is a pale yellowishgreen form, with slender, erect branches.

Retinospora pisifera, Siebold. PeA-Fruited Retiñospora, (Chamecyparis pisifera, Endlicher.) From the island of Nippon, Japan. Tree small and slender. The branches, branchlets, and foliage together form a dense mass. The fruit is small, and of "numerous imbricated scales." The Park has, as varieties of the above, variegata and nana variegata.

Retinospora plumosa, Hort. Plume-Like Japan Retinospora. (Retinospora pisifera plumosa, Hort.) Is a compact form, with small, brightgreen leaves and small branches. Hardy, and a rapid grower. Of this there are these varieties in the Park: argentea, Hort. Silver-Plumed RetinoSPORA; with the tips of the shoots at first perfectly white, but turning green later. aurea, Hort.; branchlet tips of a permanent golden color. Hardy. This is the same as the $R$. pisifera of the gardens.

Retinospora squarrosa, Siebold. SQuarrose-Leaved Retinospora. (Chamacyparis squarrosa, Endlicher; (iupressus squarrosa, Lawson.) A small, slender-branched shrub or tree from Japan, with bluish-green leaves which are recurved at the tips. Hardy here, and handsome. It, too, has produced some varieties, though none of any great value.

The following forms are in the Park, but their permanency can yet hardly be stated:

Retinospora cristata, Hoopes. A compact dwarf, with the young branchlets in tufts and of a golden-yellow color.

Retinospora elegantissima, Hoopes. "Habit dwarf and regular; growth compact and delicate; foliage yellow-tinted." 
Retinospora Hoggii pendula, llempes. Is a pendulous form, not unlike $R$. flifera, but more graceful and drooping in character.

Retinospora pygmaa, likh. Smalleatsized form of Retinospora; biyht, lively green color, and exceedingly ornamental.

Salisburia. Male and female flowers on different plants; leaves fan-shaped, veined like ferns; deciduous.

(9) Salisburia adiantifolia, Smith. Ginkgo, Maiden-Hair Tree. (Ginkgo biloba, Linnans; Salisburia Ginkgo, Salisbury.) A tall, straight tree, with an elongated conical head, and a bark suggestive of some of the poplars. Nut rare now in this country. From Japan, but hardy here.

Sciadopitys. Male and female flowers on the same plant, but in different clusters. The most striking peculiarity is in the cones, where the scales are thin and leathery and have bracts adhering to them. Under each scale are 7 to 9 free seeds. The single species in the Park is S. verticillata, Siebold and Zuccarini. Umbrella PINe. (Pinus verticillala, Siebold; Taxus verticillata, Thunberg.) It has strangely-whorled branches (encircling the stem) and leaves, the latter being 2 to 4 inches long and 2 lines wide, there being often 30 to 40 in a whorl around the stem.

Sequoia. Male and female flowers in separate clusters but on the same tree. Cones small, oval, with 3 to 5 winged seeds under each scale.

Sequoia gigantea, Torrey. Big Tree of California. (Wellinglonia giganiea, Lindley and others; Washingtonia gigantea, Kellogg.) From the Sierras of California at middle altitudes, where it grows nearly 300 feet high and 30 feet in cliameter. It was formerly supposed that these trees were over 3000 years old. It now appears probable that they are far short of this great age; most likely not more than $\mathbf{1} 800$ years old. It is in great danger of extermination from the destruction of the old trees for timber, and the killing of the young ones by fires made to clear the ground of underlorush and so allow the grass to grow for the bands of sheep which overrun the region. Not entirely harily.

Sequoia sempervirens, Endlicher. CaI.IFornia ReDwond. (Taxodium semepervirens, Lambert; Taxodium $\Lambda$ utkaensis, Lambert.) Almost as large as the "BiG TREE," and even less hardy with us. Common alout Monterey, California. This species is being rapidly consumed for lumber, and it is to the Pacific coast what the White Pine is to this.

Taxodium. Male and female flowers on the same branches but in different clusters. "Fruit of several thick, shield-shaped scales united into a glubular cone." Seeds 2 on the base of each scale.

Taxodium distichum, Richard. BALd CyPREss. (Cupressus Virginiana, Plokenel; Cupressus disticha, Linnceus.) A deciduous-leaved tree growing from Delaware southward, in low wet grounds. A most valuable timber, now coming into general use in finishing houses, etc. It altains a very large size, especially on the rich bottom-lands of the West and Suthwest. Hardy here.

Taxodium mucronatum, Tenore; which is by some regarcled as a mere variety of the above, is found in Mexico forming extended forests. To it the 
great Montezuma Cypress at Chapultepec (in Mexico) belongs. It has a diameter of 30 feet near the ground. This species is not hardy here.

Taxus. YEW. This small group of shrubs and small trees is characterized by having the male and female flowers on different individuals; the former of a few naked stamens, the latter a naked ovule in a small disk which becomes cup-shaped. Heart-wood usually red. From the temperate and colder parts of the globe. In this somewhat perplexing group Gordon has been mainly followed.

Taxus adpressa, Knight. Short-Leaved Japan Yew. (Taxus tardiva, Lanuson: Taxus baccata adpressa, Carriere; Cephalotaxus tardiva, Siebold; Cephalotaxus adpressa, Hort.) Shrub from Japan; 3 feet high, with many spreading branches. Hardy here. It has a variety stricta, Standish; which is robust in appearance and has erect leading shoots.

Taxus baccata, Linnaus. COMMON YEW. (Taxus baccata vulgaris, Endlicher.) Is a small tree or large bush from Northern Europe. Stem short, but branches many and spreading; smaller branches drooping; leaves a gloomy green. Of this we have the varieties-argentea, Loudon; Silver VARIEGATED YEW; which has silvery white striped leaves changing to strawcolor. * Cheshuntensis, W. Paul; Cheshunt Yew; is pyramidal in outline, has small leaves, and is of rapid growth. Dovastoni, Loudon, DovasTON'S YEW (which is cursed with many synonymes); has the form of the species, except that its branches are horizontal and its branchlets very drooping. Of this variety there is a variegated form which has the young leaves goldenedged, which, as they become older, change to a bright green with silver edging. erecta, Loudon, ERECT YEW ; is a slender, stiff, erect variety, which is more commonly known in gardens as 7 axus erecta. ericoides, Hort.; HEATH-LIKE YEW; is I or 2 feet high, with small dark foliage and small erect twigs. fastigiata, Loudon, IRISH YEW; has the outline of a Lombardy Poplar, the branches being stiff and erect; leaves in tufts or scattered, but not in 2 rows as most Yews have; berries also are oblong instead of round. The variety has also produced 2 (at least) variegated forms. * fructuluteo, Loudon; has berries of a striking golden color. glauca, Carriere; leaves dark green on upper surface "and bluish and glaucous gray on the under. Bark of the young shoots is a rusty-brown color." nana, W. Paul; is a solid little dwarf, with leaves longer and darker than the species. sparsifolia, Loudon; which is the same as the variety monstrosa of the gardens; has the leaves arranged around the branches, but the branches spreading. * variegata, Loudon; has the leaves edged with a golden-yellow color.

Taxus brevifolia, Nuttall. California Yew. (Taxus Boursieri, Carriere; Taxus baccata Americana, Douglas; Taxus Lindleyana, Murray; Taxus occidentale, Nuttall.) A middle-sized tree from our Northwest coast; leaves long (nearly an inch), slightly curved; branches slender, very long, drooping, and with a yellowish bark.

Taxus Canadensis, Willdenozv. Canadian Yew. (Taxus baccata Canadensis, Loudon; Taxus baccata minor, Nichaux; Taxus procumbens, Loddiges; Taxus Canadensis major, Knight.) This in a wild condition is a muchbranched, straggling, half-creeping shrub, and, so far as shape or outline is concerned, it has little or no beauty. It may, however, be pruned into almost any shape. Has a rather sombre hue in winter. The variety Washingtoni, Hort., has a vigorous growth, with large, somewhat curved leaves slightly tinged with a rich golden color. It is also known in gardens as Taxus Washingtoni and Taxus Canadensis aurea. 
Taxus cuspidata, Siebold. ABrupt-POINTED YEw, Is a desirable, tall, handsome shrub or small tree with ascending branches, and leaves very dark green above and lighter green below. Does not appear hardy, if one may judge from its absence in our nurseries. From Japan.

Thuiopsis. Japanese trees, with whorled pendent branches, the smaller twigs being very numerous and 2 -ranked. The leaves are opposite, overlapping, or sickle-shaped, and sharply pointed. The small cones have coriaceous, round scales, under which are 5 seeds; the seeds have a notched wing.

Thuiopsis dolabrata, Siebold. Hatchet-Leaved ARbor Vite. Thuja dolabrata, Thunberg; Platycoides dolabrata, Spach.) Tree 40 to 50 feet high, with branches drooping at the points. According to Thunberg, "it is a lofty, vast, and beautiful tree, of all evergreens the fairest." It requires a rather moist situation. The following varieties appear in the collection : nana, Siebold: is the Dwarf Hatchet-Leaved Arbor Vitæ, and also appears in gardens and in garden lists under the name of Thuiopsis dolabrata lativirens. It is a variety seldom over 4 feet high, with the leaves and branchlets of a light green color, like an erect Club Moss. The Japanese cultivate it in pots. Also a desirable rock-work ornament. variegata, Fortune; VARIEGATED HATCHETLEAVED ARBOR ViTæ; differs from the species in having branchlets and leaves of a pale yellow color intermixed. The form known as Thuiopsis borealis, Fischer, is Cupressus Nutkaensis, Hooker, of this Catalogue.

Thuja. Arbor Vite. Sexes separated in small clusters, but on the same branches, the male (stamens) each having 4 anther-cells, the female clusters of a few scales, each of which bears a pair of erect ovules. Spray flat, bearing awl-shaped scales and blunt-pointed scales, the latter shorter than the others and united to the branch. Gordon's Pinetum has been mainly followed in these species.

Thuja gigantea, Nuttall. Giant Arbor Vite, Yellow Cypress. (Thuja plicuta, Lambert; Thuja Douglasii, Nultall; Thuja Menziesii, Doug. las.) One of the striking trees of our Northwest coast, growing often I 50 feet high. The inner bark is used by the Indians to make cloaks, mats, sails, ropes, and clothing. It does not appear to be entirely hardy here.

Thuja occidentalis, Linnous. American Arbor Vite, White Cedar. Native; from the cooler parts of Pennsylvania, northward, forming often extensive cedar swanms. Grows 20 to 50 feet high; yields a pungent oil ; wood is durable, but too soft to hold nails firmly. The foliage becomes rather dingy as cold weather approaches. It has the following varieties: * argentea, Carriere; has some silvery white color along with the green. compacta, $R$. Smith; is conical in outlne and compact in growib. cristata, Cripps; has the creited and spreading sinall branchlets recurved and cockscomb-shaped. densa, Gordon, is the variety compacta of Stendish; a conical bush, with stout, compact branches and horizontal, fan-shaped branchlets of a fine glossy

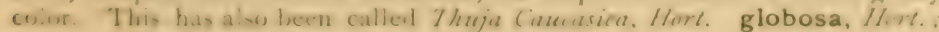
is a dwarf bush, round in uutline and very dense. Hoveyi, Horl.; Hovey's American Arbor Vite; is also known as Thuja Hoveyi, Hort.; a compact

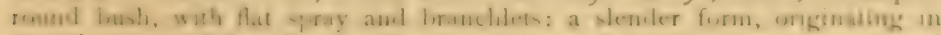
America. pendula, Gordon; branches along the main stem reverted, and the branchlets for the most part clustered or tufted towards the end of the branches and still more declined. variegata, Loudon; has some of the branchlets of a pale yellow. vervzeneana, Hort.; a golden-tinted variety procluced in Gihent. It has produced a new form also. 
Thuja plicata, Don. Nootka Snund Arbor Vita. (Thuja occidentalis plicata, Loudon; Thuja occidentalis asplenifolia, Hort.; Thuja odorata, Marshall.) Becomes quite a tree; has the branchlets strangely twisted; foliage is a deep bright green. Variety minima, $R$. Smith, is an exceedingly compact little form, of very slow growth.

Thuja Standishii, Gordon. Standish's Japan Arbor Vite. (Thuja gigantea Standishi, Parlatore?) Is a handsome, good-sized tree from Japan.

Thuja Tatarica, Loddiges. TARTARIAN or Siberian ARbor Vite. (Thuja Tatarica Wareana, Hort.; Thuja Sibirica, Linneus; with a host of other synonymes.) This is a beautiful, regularly conical, small tree, dark green in color and compact in growth. Hardy. Hoopes, who is a most competent authority, insists that this is but a form of $T$. occidentalis. Under $T$. Tatarica Gordon places T. pyramidalis both of Tenore and of Carriere.

The following newer or less-known varieties of Thuja occidentalis appear: rotundata, Hoopes; which is a dwarf, deep green in color, and dense in structure, with a peculiar crested appearance. Doii, Doe; a variegated form, with yellow-speckled stems and leaves. Buchanani, Doe, is another variegated form, with abundant yellow dots on the foliage. lutea, Doe; a conspicuously golden-yellow variegated shruh, which retains its color both in the sun and with age. The variety nana, Hoopes, is a different plant from that of the same name by Gordon and Carriere. Variety Brinkerhoffii is of a conspicuous golden yellow, and very attractive in early spring.

Besides the above there are Thuja occidentalis ericoides, Hort.; which is Retinospora Ellwangeriana, Barry. Thuja occidentalis excelsa of the garden lists, which may be Thuja excelsa of Bongard, which is Cupressus Nutkaensis, Hooker. Thuja glauca, Hort., is Biota orientalis gianca, Pince. Thuja Japonica, Hort, is Biota orientalis Sieboldii, Endlicher. Thuja occidentalis, Hort., is Biota orientalis monstrosa, Carriere. The popular little Tom Thumb Arbor Vitæ Gordon puts under Retinospora Ellwangeriana, Barry.

Torreya. Male and female flowers in the axils of the leaves, but on different trees. "Anther-cells 4, attached to the under side of the shield shaped scale." The female flowers maturing into a 1 -seeded stone fruit. A small group of trees from California, Florida, China, and Japan, the wood of which is yellow, heavy, and fine-grained, but both stem and leaf have an unpleasant odor when bruised.

Torreya Californica, Torrey. California Nutmeg, Stinking Yew. (Torreya myristica, Hooker.) A tree from the California Sierras, 20 to 40 feet high. Foliage is beautiful, and the bark is little like that of an ordinary conifer.

Torreya grandis, Fortune. (Caryotaxus grandis, Henk. and Hochst.; Cephalolaxus grandis, Hort.; Cephalotaxus umbraculifera, Siebold.) It appears in Gordon's Pinetum under the last name. From the mountainous parts of the north of China, where it becomes a good sized tree. This species is devoid of the unpleasant odor which characterizes the others.

Torreya nucifera, Zuccarini. Nutbearing Torreya. From Northern Japan, where it becomes a good-sized tree. Not much tested here yet.

Torreya taxifolia, Arnott. Tree from Florida; handsome, but with the usual bad odor of the group. Called also STINKING YEw. 


\section{CORNACEA. Dogwood Family.}

Mostly shrubs or trees; leaves simple; flowers inconspicuous; calyx-tube adherent to the ovary in the fruitful flowers, and its short lobes free; stamens equal in number to the separate parts of the corolla; fruit is a berry or a stone fruit with a single suspended ovule or seed in each cell. This family is one of some importance to mankind, furnishing valuable hard-wood, food, and important remedies.

Aucuba. Pistils and stamens on different plants; flowers are dark purple, inconspicuous, in clusters from the axils of the opposite leaves, which are often marbled with yellow, and are thick, shining, and evergreen. The single species we have is:

Aucuba Japonica, Thunberg. The mature red berries of which are quite handsome. From Japan.

Cornus. Cornel, Dogwood. Flowers perfect, in close or flat-topped clusters; sometimes with a conspicuous flower-like involucre, which encloses many small flowers; leaves opposite, or nearly so; bark very bitter, and once much used as a tonic.

Cornus alternifolia, Linneus. Altervate-Leaved Cornel. Branches green or green and streaked with white; ovate leaves, alternate or sometimes nearly opposite, long-pointed, whitish on the under surface; fruit blue, on red stalks. Native and common.

* Cornus asperifolia, Michaux. Rough-Leaved Dogwood. Young branchlets are rough pubescent; leaves rough hairy on the under surface, soft and downy on the upper; seed small, nearly round, and nearly smooth, with very slight furrows. Native of the States along the middle Mississippi River, where it becomes a small-sized tree.

Cornus florida, Linnaus. Common Dogwood, Flowering Dogwood. Too well known to need a description, and attractive enough for a place in any grounds. Native to the Park.

* Cornus circinata, L'Héritier. Round-Leaved Corvel or Dogwood. Dark-green branches somewhat warty-dotted; roundish leaves woolly on under surface and 5 inches long; fruit blue. Native.

Cornus Japonica, Thunliers. IAliv Docwoon-TRE.E. Leaves whiti-h on the under surface; flowers whitish, and in heads, which are surrounded by an involucre (like that of our Flowering Dogwood, but smaller).

Cornus mas, Linneus. European Cornel or Dogwood. A large shrub or small tree; leaves oval; flowers yellow (coming before the leaves), in a small cluster, and surrounded by a small 4-leaved involucre. Native of the East, and ranges widely over Europe and Asia. Fruit edible.

Cornus paniculata, L'Herilier. Paviclen Cornel. A much-branched native shrub, 4 to 10 feet high, which has pure white flowers and plenty of them. 
Cornus sanguinea, Linnaus. EURopean Red OsIER. An erect shrub from Europe; leaves somewhat downy on the under surface; flowers white; fruit dark purple or blackish, not edible; young branches purple. Native also of Asia.

Cornus sericea, Linnaus. Silky Dogwood, Kinnikinnik. Branches purplish, younger branchlets, stalks, leaves, etc., a lighter dull color; 3 to $8 \mathrm{feet}$ high. Native. Used by the Indians of the Lake Superior region as a substitute for tobacco.

* Cornus stolonifera, Michaux. Red Osier Dogwood. Young smooth branches of a bright red or slightly purple color; leaves ovate, slightly rough on both surfaces, and whitish on the lower; flowers white. Native. Multiplies freely by "suckers." The Cornus alba of the gardens is only another name for the same species.

Cornus stricta, Lambert. STIFF CORNEL. A low shrub common in wet places to the south of us; smooth branches brown or red; leaves smooth and green.

Nyssa. Sour Gum Tree, Tupelo, Pepperidge. Tree with male and female flowers united or separate on the same tree or separated and on different trees; flowers greenish, crowded, and inconspicuous; leaves alternate and entire. Our species,

Nyssa multiflora, Wangenheim; is a large common tree; leaves shining green in summer and bright crimson in autumn. The tough, hard-splitting wood once much used for making wagon-hubs, a demand which is now more generally met by the Rock-Elm.

\section{CUPULIFERA. Oak Family.}

Trees or shrubs with alternate and simple straight-veined leaves. Male and female flowers separated, but on the same plant; female flowers solitary, clustered, or spiked, furnished with a cup-like often prickly involucre (as in the acorn, beech-nut, and chestnut); seed-leaves thick, fleshy, and often edible. An order of great importance to man.

Carpinus. Iron-Wood, Hornbeam. Staminate flowers in drooping cylindrical clusters, small; fertile flowers loosely spiked; when mature the fruitleaves are 3-lobed, halberd-shaped, and somewhat notched on one side.

Carpinus Americana, Michaux. American Hornbeam, Blue or WATER BEECH. A middle- or under-sized tree, with ovate, toothed leaves and 5- to 7-nerved fruit-bracts; bark smooth, white or grayish white; wood, when dry, very hard and elastic.

Carpinus Betulus, Linnaus. European Hornbeam. Leaves ovate elliptical, fruit-leaves 3 -nerved. Grows in Europe and Asia, and is much used abroad as a hedge-plant.

Castanea. Chestnut. Cupule 2- to 4 -flowered, forming a prickly, hard bur 2- to 4-parted when ripe. Wood and fruit both important to man. Here we follow Gray as to the relation between the European and the American Chestnut. 
Castanea vesca, Limnaus. European Crestnut. Leaves acute at either end, teeth sharp; nuts $3 / 4$ inch to 1 inch across, 2 to 3 in a bur. Native of Europe and Asia.

Variety Americana, Mickaux. American Chestnut. Leaves acute at hase; teeth less sharp and nuts smaller and sweeter than those of the European Chestnut. Native in the Park.

* Castanea pumila, Michaux. Chivquapin. Oblong leaves white and downy on the under surface; single nut in a bur. Nuts edible and sweet. A small native tree.

Corylus. Hazel-Nut, Filbert." "Involucre enclosing the large bony nut, leafy, coriaceous." Sterile flowers in hanging cylindrical clusters, anthers of a single cell.

* Corylus Americana, Waller. Wild Hazel-Nut. Pointed leaves round, heart-shaped; fruit enclosed in the 2 nearly separate, cut-toothed bracts, which are thickened at base. A common native.

Corylus Avellana, Linneus. Common European Hazel-Nut. Fruiting bracts distinct, cleft at the apex into palmate lobes. Native of the Mediterranean region. Variety purpurea, Loudon, has purple leaves, and is sometimes called atropurpurea in gardens.

Corylus Colluma, Linnaus. Constantinople Hazel. (Corylus Pontica, Kock.) Lower fruit-leaf ovate-lanceolate, somewhat divided, upper one larger, many-cleft, with the divisions long-pointed and much prolonged beyond the nut. Eastern Mediterranean region.

Fagus. Bfech. Staminate flowers in a small head; female cluster a cupule with 2 flowers, which when ripe is 4 -parted and contains 2 sharp-angled triangular nuts.

Fagus ferruginea, Aiton. AmErican BeEch. Leaves oblong or ovate, pointed, sharply toothed, the straight veins pointing to the teeth. A noble native tree, the wood of which is hard and valuable. Common in cold woods.

Fagus sylvatica, Linnaus. European BeEch. Leaves broader and shorter, somewhat hairy, wavy-toothed, and some of the veins pointing to the notches of the leaves. There are the following varieties of it in the Park: colorata, Alph. De Candolle; is known in gardens as purpurea, or Purple Beech; has leaves variously purple or copper-colored. cristata, Loudon; has the crisped leaves in small clusters. heterophylla, Loudon; is sometimes called laciniata and asplenifolia; its leaves are variously cut or incised. pendula, Loddiges; is a garden form with drooping branches.

Ostrya. Hop Hornbram. Each ovary with two long stigmas, and this and the nut into which it develops-are in a closed bag. These bags are gathered into a hop-like fruit-cluster. The single species with which we are

I Phillis

Was shape into a nuttee tree,

That all men it might see:

And after Phillis, Philiberd

This tree was cleped." - From Loudon, P. av17. 
concerned is Ostrya Virginica, Willdenozw. A small tree, native of the Park, with sharply double-toothed leaves; seed-sac is hairy at the base. Wood hard when dry.

Quercus. OAK. "Cupule [acorn-cup] I-flowered, scaly, and entire, nut hard" and depressed globose, round, or cylindrical. In the following determination of the Oaks the best has been done that was possible in want of suffcient material and in the absence of the authorities for the names. ${ }^{\mathrm{I}}$ It is thought, however, that though but provisionally given the names are in the main reliable and represent the latest authoritative views upon the Oaks.

Quercus alba, Linnaus. White OAK. Native tree, which matures its fruit in a single year (annual-fruited); leaves more or less deeply sinuatetoothed or lobed; under surface pale or glaucous, upper surface bright green; acorns edible, but astringent (hence not pleasant-tasted). A most hardy tree, and a most valuable timber.

Quercus alnifolia, Pöch. Mountains of Cyprus; shrub or small tree; leaves $I$ to $I I / 2$ inches long, $I / 2$ to $I$ inch wide. Evergreen in its native land. Is this the $Q$. alnoides of the Catalogues?

Quercus aquatica, Walter. WATER OAK. Tree maturing its fruit in two years (biennial-fruited); leaves thick, smooth, and shining, somewhat undulate or lobed at tip. Maryland and southward. Q. laurifolia, Michaux, is given by $\mathrm{De}$ Candolle as a variety of this, and by Chapman as a variety of $Q$. Phellos, and in Arboretum Muscaviense as a variety of Q. imbricaria (see Q. laurifolia of this list). Wood tough, but said by Michaux not to be desirable, and the bark is not much used in tanning.

Quercus bicolor, Willdenoze. Swamp White OAK. Annual-fruited; of the Chestnut Oak group; leaves obovate or oblong, variously lobed; soft downy along the under surface; upper scales of the acorn-cup with long slender tips. A tall tree, furnishing good timber. It is the Q. Prinus tomentosa of Michaux the elder in his history of the Oaks. Q. Michauxii, Nuttall, is regarded by Engelmann as a sub-species of Q. bicolor. Q.pannosa of the German gardens appears also to belong here.

Quercus castanæfolia, C. A. Meyer. Is a biennial-fruited species from the Caucasian region; leaves 3 to 6 inches long and $I$ to 2 inches wide, acutely or obtusely sinuate-toothed, with prominent nerves beneath. This tree must not be confounded with another ( $Q$. Prinus monticola, Michaux) to which the above name has also been given.

Quercus Catesbri, Michaux. Turkey OAK, Barren Scrub OAK. Is a small, biennial-fruited tree, ranging from North Carolina to Florida; leaves smooth, thickened, deeply divided, and lobes bristle-pointed. Valuable only as a fuel.

Quercus Cerris, Linnezs. TURKrsh or Burgundy OAK. (Quercus haliphlcos, Lamúert; Q. Austriaca, Willdenow.) Tree with biennial fruiting; leaves oblong or obovate, sinuate or lobed. Widely distributed over Southern

\footnotetext{
1 It may not be out of place here to state that the mere name of a plant is incomplete unless the authority for the name follows. For example, the same name may have been given to two very different plants by different authors. In such a case the addition of the authority to the name proper at once removes all doubt.
} 
and Central Europe. It has produced a number of well-marked varieties, of which the Park has-bullata, Loudon; apparently a garden form, with blis. tered or rough leaves. laciniata, Loudon; with narrow almost pinnately. diviled leaves, the lobes of which are acuminate pendula, Neill; is a garden form with conspicuously drooping lranches. subperennis, Alph. De Candolle; has long been cultivated in British gardens under the name of $Q$. denfata, Wutson. To this same variety Alph. De Candolle refers both Q. Cerris Fulhamensis, Loudon, and Q. Cerris Lucombeana, Loudon; which has also produced a form (crispa) with curled-edged leaves. May not asplenifolia and Complonifolia of the gardens be the same?

Quercus cinerea, Michanx. Upland Willow OAK. From Virginia southward. A small, biennial-fruited tree; leaves oblong, hairy beneath; acorn with a saucer-shaped cup. Q. Phellos, Spach, is a synonyme. 'The variety pumila, De Candolle, or Q. sericea, Willdenow, is placed under Q. pumili, Halser, of this list.

Quercus coccinea, Wangenheim. Scarlet OAx. Large, biennial-fruited, native tree of the Black Oak group; the smooth, deeply-cleft leaves turning red in autumn. Wood open-pored, making bad staves, poor fuel, and is seldom used in the arts. Bark, however, used in tanning. It is sometimes wrongly called Spaxish Оak, which is $Q$. falcata, Michaux.

Variety tinctoria, Gray. Quercitron, Yellow-Barked, or Black OAK; is now generally regarded as a variety of the above, "with more pointed and longer buds, broader less lobed leaves, and more pointed acorns." It is Q. Americana, Plukenet, according to Loudon. The bark is used in tanning, and the cellular tissue furmishes the quercitron dye. Wood is open-pored, but made into staves for barrels to hold the less penetrating liquids. Wood fair in quality, but by no means equal to that of the White Oak. There are other less important varieties.

Quercus dentata, Thunberg? Native of Japan. Acorn matures in a single year; young branches densely brownish hairy; obovate leaves wavy margined or lobed, lobes obtuse, but with short projecting veins. (From want of proper material, and from having no authority for the name, it is not certain that this may not be the form of $Q$. Cerris cultivated in British gardens as $Q$.deniata.)

Quercus falcata, Michaux. SPANish OAK. A good-sized, biennialfruited tree, ranging from New Jersey to Illinois and southward; acorn roundish; leaves deeply and sharply lubed, lobes somewhat scythe-shaped, except the straight terminal one. Wood poor, but bark may be used in tanning.

Quercus Georgiana, M. A. Curliss. Georgran OAK. A biennial-fruited shrub of the Black Uak group; leaves smooth, narrowly oval or obovate, entire or wavy-toothed, or even lobed. "Acorn-cup shallow, with its scales nearly glabrous, obtuse, and appressed." Regarded by Engelmann as coming very near Q. palustris. Confined, so far as now known, to Stone Mountain, in Georgia.

Quercus heterophylla, Michaux the younger. Bartram's OAK. A biemnial-fruited, goud-sized tree, with oblong or somewhat wedge-shaped more or less lobed leaves. Considered by Alph. De Candolle as a mere variety

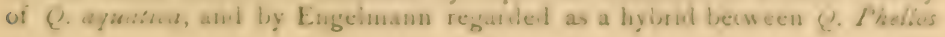


and Q. coccinea. From its range increasing as we know it better, and from its being found away from either of its alleged parents, it will likely come to he regarded as a distinct species. Specimens of the tree have been obtained for the Park collection through the exertions of Hon. Eli K. Price.

Quercus Ilex, Linnaus. European Evergreen or Holly Oak. Fruit annual; young branches and under surface of leaves velvety hairy; leaves thick, leathery, elliptical to oblong, margins toothed or entire, smooth on upper surface. Ranges throughout the Mediterranean region and to Central Europe. Has many varieties, of which the following are in the Park collection: Ballota, Alph. De Candolle; has the base of the leaves round and the under surface quite hairy; common in Spain and Algiers, and by many regarded as a distinct species. crispa, Loddiges, is a garden form with curled edges to the leaves. There are also less clearly marked varieties, such as laurifolia and rotundifolia.

Quercus illicifolia, Wangenheim. BEAR or BLACK SCRUB OAK. Is a biennial-fruited branching bush of the Black Oak group; leaves obovate, wedge-shaped at base, with 3 to 7 angular lobes, white hairy on the under surface. Barren ground from New England to Kentucky. Of no particular use. It is the Q. Banisteri, Michaux.

Quercus imbricaria, Michaux. Laurel or Shingle OAK. Tree 40 to 50 feet high, biennial-fruited, with narrow-oblong, thick, entire, or wavy margined leaves, which are smooth and shining above and downy beneath. From this latitude south, but most common west of the Alleghanies. Wood not first-class, but may be split into shingles. There is a garden form of this, -latifolia.

Quercus laurifolia, Michaux. LAUReL-LeAved OAK. A good-sized tree, with biennial fruit; leaves entire or lobed, lanceolate, or oblong, and widest about the middle. Often regarded as a variety of Q. aquatica, but now separated from this by Engelmann. Southern States.

* Quercus Leana, Nuttall. LeA's OAK. Ranges through Southern Ohio and Illinois sparsely. Regarded by Drs. Gray and Engelmann as a hybrid between $Q$. imbricaria and $Q$. coccinea. Others think it will prove a distinct species, as it has already been doubtfully recognized by Alph. De Candolle (though in his case probably on insufficient grounds). Leaves 3 to 6 inches long, $1 \frac{1}{2}$ to 4 inches wide, margins lobed, when mature smooth on both surfaces, lobes bristle-tipped; fruit like that of the Scarlet Oak.

Quercus lyrata, Walter. Overcup OAK. Fruit annual; obovate oblong leaves, 7 - to 9-lobed, hairy beneath, crowded on the ends of the branches; roundish cup, with rough scales, which almost enclose the large nut. Swamps of the Southern States, where it attains a large size and furnishes a most valuable timber.

Quercus macranthera, Fischer. LARGE-FlowerED OAK. (Q. pubescens, Szovits.) Annual-fruited; from the mountains of Caucasia and Georgia; branchlets densely covered with spreading hairs; leaves obovate, entire margined or somewhat deeply lobed, brown hairy on the under surface.

Quercus macrocarpa, Michaux. MOSSY OVercup OAK, BUR OAK. Annual-fruited large tree of the White Oak group. Known by its large acorns with fringed margin to the cup, which more than half covers the nut, and often distinguishable by the corky ridges to the branches; leaves oblong, decidedly 
wary cut or lohed. Ranges from New England to Wisconsin and Kentucky. The variety olivaeformis, Michaux, is another form, with smaller acorns in more shallow but still fringed cups; leaves vary greatly, from being entire to very deeply divided; branches may or may not be corky.

Quercus Mongolica, Fischer. Mongolian OAK. Annual-fruited; leaves obovate, wedge-shaped towards the base, and towards the top somewhat wavy or lubed.

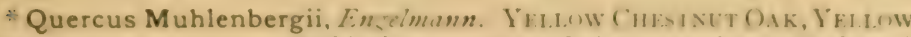
OAK. (Quercus castanea, M/uhlenberg; Quercus Prinus acuminata, Michaux.) Middle-sized tree, with leaves strikingly like those of the chestnut; annualfruited; bark pale and thin; wood very tough. Common with us. The original name (castanea) is now given to a Mexican oak.

Quercus myrtifolia, Willdenow. MYrTle-LeAved OAK. (Quercus Phellos, war. arenaria, Chapman; Q. aquatica, var. myrtifolia, Alph. De Candolle.) From the Carolinas and Georgia. An evergreen shrub; leaves ovate to round, heart-shaped at base, I 1/2 to 2 inches long, thick, margins revolute; acorn-cup $1 / 2$ inch wide, shallow, its scales ovate-triangular and bluntpointed.

Quercus nigra, Linneus. BLACK-JACK, BARREN OAK. A small annualfruited tree, with broadly wedge-shaped, somewhat 3 - to 5-lobed leaves; the coarse scaly cup is top-shaped. (Quercus ferruginea, Michaux; Q. Mlarylandica, Catesby; and Q. quinqueloba, Engelmann, are synonymes.)

Quercus palustris, Du Roi. Swamp, Spanish, or PIN OAK. A goodsized tree of the Black Oak group. Native to the Park. Biennial-fruited; leaves deeply cleft, siruses rounded, lobes divergent and acute; acorn over $1 / 2$ inch long, but cup very flat and shallow; limbs rather drooping. Timber is of middling quality only.

Quercus Phellos, Linnous. Willow OAK. An annual-fruited native Oak, 30 to 50 feet high, with thick, entire, willow-like leaves, by which it is well distinguished from all the other Oaks in our region. Low woods from New Jersey to Kentucky, but more common southward. Q. Phellos cinerea is placed under $Q$. cinerea.

* Quercus Prinus, Linneus. Chestrut OAK. A branchy, midllesized, annual-fruited native tree; leaves oblong, wavy, blunt-tonthed, rounded at base, sharp at tip; acorn long and in a thick cup. Variety humilis, Marshall. DWarf Chestnut OAK, or Chinquapin OAK. (Q. Prinus, var. Chincapin, Mickass the younger; $Q$.prinoides, Willdenowv.) Has undulate, hardly sharp-toothed leaves; sessile acorns in moderately deep cups which have swullen scales. It is a mere shrub here, but becomes a tree 30 feet high west of the Mississippi. Variety monticola, Michaux. Rоск CHzstrut OAк. (Quercus montana, Willdenow.) This Dr. Engelmann regards as a distinct species, and as the form on which the original $Q$. Prinus was founded by Linnaus. Bark of young trees smooth, of old, rough and furrowed; leaves shick, pale on lower surface; fruit with a deep rough cup and an acorn 1 to $1 \%$ inches long and $I$ inch thick. It is most common in the Suthern mumtains.

Quercus pubescens, Loddiges' Calalogue. (Loudon, p. 1731, under $Q$. peciunculala, is not the probescens of Willdenow. For the latter, see Loudun, P. 1736 , where Q. lanuginosa, Lamberl, is given as a synonyme.) 
Quercus pumila, Walter. Running OAK. Shrub from South Carolina, which spreads by its stolons and hence forms extensive thickets. The Park has the variety sericea? ( $Q$. sericea, Willdenow; $Q$. Phellos sericea, Aiton), which has narrow or ovate-lanceolate leaves, always silky white on under surface, 4 inches long, $11 / 4$ inches wide.

Quercus Robur, Linncus. English or European OAK. From Europe and Western Asia, where it sometimes forms vast forests; fruit matures in a single year; leaves vary much in shape, from obovate to elliptical-cordate, obtuse or acute at base, margins lobed, lobes obtuse or acute; hemispherical acorn-cups, with hairy, ash-colored scales. The various forms are now divided by the best authorities into two sub-species:

Sub-species pedunculata ; has short petioles to the leaves and long peduncles to the fruit. It is divided into many varieties, of which the Park has the following: Apennina, Alph. De Candolle. From the drier regions of Southern Europe; young leaves covered on the under surface with dirty-colored whitish hairs, but smooth or nearly so on the upper surface. It is $Q$. pubescens, Loddiges. There is also a variety Apennina under the next sub-species, with which the above must not be confounded. fastigiata, Lambert; has the flowers collected in erect clusters. It comes from Calabria and Southern France. The varieties of the gardens pyramidalis cucullata and pyramidalis punctata belong here. foliis variegata, Loddiges; has leaves variegated with white and red. Haas, Alph. De Candolle; has the branches velvety or smooth; leaves with large obtuse lobes, and with short stellate hairs on the under surface, and also hairy on the upper surface; acorns large. laciniata, Alph. De Candolle. Leaves elongated, nearly entire or irregularly gash-lobed, lobes acute or obtuse. From the English grounds, where it appears also under the names of Q. filicifolia, Q. Fennessi, and Q. pedunculata heterophylla. purpurascens, Alph. De Candolle; has purple leaves. Q.purpurea, Loddiges, and var. foliis cupreis of the gardens, appear to belong here. Thomasii, Alph. De Candolle; has rather hairy young branches and leaves, and also large fruit.

Sub-species sessilifiora; has longer petioles to the leaves and shorter peduncles, or none, to the fruit. Its varieties are as follows: aurea, Alph. De Candolle. Branches smooth or nearly so; leaves oblong, deeply cleft or undulate-lobed, lobes obtuse, smooth above and slightly hairy beneath. The forms aurea maculata, aurea tricolor (aurea bicolor), albo mucronata, foliis pulverulentis, appear to be mere variegated garden sports of the above. bullata, Alph. De Candolle. From Asia Minor; has branches and leaves smooth; leaves deeply lobed; scales of the acorn-cup are somewhat enlarged. The same name is also given to a variety of a quite different tree from Guatemala. communis, Alph. De Candolle. Branchlets nearly smooth; leaves large, sparsely hairy, and not deeply lobed. This form often appears in parks under the name of Q. sessiliflora, Salisbury. A synonyme is Q. Iberica, or Spanish Oak. It comes from Southern Europe and Western Asia. parvifolia, Alph. De Candolle. Leaves I to 3 inches long and $1 / 210 \mathrm{I} 1 / 2$ inches wide, ovate lobes wavy dentate and somewhat pointed. From France. This form is the Q. sessiliftora, Loudon; and Q. laciniata of some lists comes under the same head. ${ }^{x}$

Quercus rubra, Linnaus. RED OAK. A biennial-fruited, large tree, growing naturally in the Park. It furnishes an open-pored, poor timber, strong,

1 We cannot at present say whether var. Loveti, Lovet's Cut-Leaved Oak, belongs to the sub-species pedunculata or sessiliflora. It has " cut foliage of a rich dark shining green color." 
but not durable; leaves cleft about half-way down, notches in the leaves broad, lobes sharp- or bristle-pointed, turning dark red in autumn; acorn large, nearly as broad as long, in a rather shallow cup. Engelmann consicters $Q$. ambigrua of Michaux a form of this; and $Q$. borealis is another name, given on account of its high northern range. *Variety runcinata, Engelmann; is a narrow lobed dentate leaved form from near St. Louis, Missouri.

Quercus sideroxyla, Ilumbilt and Bonfland. Is a liemnial-fruiterl, tall tree from the temperate regions of Mexico. Leaves oblong, or with a wedgeshaped base, with spine-tipped teeth above the middle, slightly hairy on the under surface. Young branches velvety.

Quercus Suber, Linnaus. CORK OAK. This tree is a native of Southern Europe, and common in Portugal and France, whence much of the cork in the market is derived. Annual-fruited, snallish tree, with the young branches and under surface of the leaves velvety hairy; leaves oval or oblong, acutely tonthed, or sometimes entire; acorns long, cylindrical, nearly half immersed in the cup. Of great importance in the arts. The museum of Horticultural Hall shows specimens grown in Carolina, as Michaux long ago asserted it could be.

Quercus stellata, Wangenheim. Post OAK, RovgH or Box White OAK. (Quercus oblusiloba, Michaux, in Gray's Manual; Q.villosa, Waller.) Small, annual-fruited tree of the White Oak group. Wood clense and durable; thick leaves deeply cleft into ohtuse wavy lobes, grayish downy on under surface, paler and rough above. Native, and common in poor soil. logue.

Quercus tinctoria, Bartram. See Q. coccinea, var. tincloria, of this Cata-

Quercus Toza, Bosc. Pyrenean OAK. (Quercus Pyrenaica, Willdenow; Q. Zauzin, Persoon.) Branches pubescent; leaves 2 to 4 inches long and $1 / 2$ to $I 1 / 2$ inches wide, obtuse, heart-shaped or wedge-shaped at base, upper surface dark green and covered with stellate hairs, densely brown hairy, more or less deeply lobed or cleft. From Southwestern Europe. The Arboretum Muscaviense places Q. camata of the gardens here.

Quercus Turneri. TURNer's OAK. Under this name two distinct trees are known, and in want of proper material we cannot decide which one is intended by the invoice. They are either Q. Lusitanica, Webb, var. brevicupulata, Alph. De Candolle, with leaves obtusely or sharply crenately toothed, and densely hairy on the under side; or Q. Turneri of the gardens, which is Q. pseudosuber, Santi, the leaves of which are ovate or oblung, teeth spinytipped, and buth branchlets and leaves with very short stellate hairs; bark curky. Probably the latter is intended.

* Quercus undulata, Torrey. "A scrubby White Oak of the Rocky Mountain region, and through Arizona; annual-fruited; very variable in foliage and to some extent also in stature and habit." Acoras edible, rather sweet, though still astringent.

Quercus Vallonea, Kolschy. Great Pricki.y-Cuppen OAR. (In part Quercus Asilops, Linncus.) Younger parts dencely covered with very short, siellate white hairs; oval leaves ohtuse or cordate at base, irregularly and sharply toothed; cup nearly globose, the upper scales of which are linear and 
recurved; acorn proper an inch in diameter. From Southern Europe. The variety brevicrenata is from Palestine. The acorn-cups are an article of commerce and largely used in tanning.

* Quercus virens, Aiton. Live-OAK. Southern States, from Southern Virginia south along the coast or in low grounds; biennial-fruited, large tree, furnishing a most durable and valuable timber; branchlets hairy; oblong and obtuse leaves, smooth and shining on upper surface and hoary on lower; fruit on a long peduncle. There are two varieties. The hardiness here of both the species and its varieties is more than doubtful.

The following are found in the Park invoices and recognized in the Arboretum Muscaviense, but so far as we can see are not to be found (at least under the same names) in the Prodromus of De Candolle:

Q. ajudaghiensis, Stevens; of the Q. rubra group.

\section{Q. Afghanistanensis, Bth.}

Q. Hartwissiana, Stevens; of which Q. Iberica of the gardens is quoted as a synonyme.

Q. Pannonica, Bth. Catalogue. Hungarian OAK.

Q. pectinata, Hort. Said to be an elegant variety and,near Q. Robur pedunculata filicifolia.

The remaining names on the Park invoices we have no sufficient material for determining, and hence for the present they are wholly obscure to us, though doubtless in most instances well known to propagators:-atropurpurea, Bombyx glabra, concordia, Fordii, Hudsonica. Under Q. Robur pedunculata there are given nigra, nigricans, and rubicunda. Besides the above there are nobilis, Speensis,? sanguinea, Zungin splendens, and heterophylla Hentzei?

\section{EBENACE $Æ$. Ebony Family.}

Hard-wood trees; leaves entire and alternate; petals united into a more or less lobed corolla; ovary with a single seed hanging in each cell; berry with large, hard-coated seeds. The ebony of commerce is furnished by foreign species of this order.

Diospyros. Persimmon. Flowers with the pistils and stamens separate or together; 4 to 6 lobes to the calyx and corolla each ; stamens variable in number according to the species; persistent calyx adhering to the fruit, which is edible when fully ripe or after severe frost.

Diospyros costata. Said to be a new introduction from Japan; unknown to us.

Diospyros Kaki, Linneus. Japan Persimmon. Parts of the calyx and corolla in 4; corolla-lobes obtuse; stamens 16 to 24 , adnate to the corolla; leaves ovate or elliptical, 3 to 5 inches long by $11 / 4$ to 2 inches wide. The fruit is an important article of food in Japan, where it has long been cultivated 
and has produced many varieties which vary in size, shape, and flavor. Worthy of introduction here, as, after being fairly started, it endures the climate well.

Diospyros Lotus, Limnens. Parts of the calyx and corolla each in 4; leaves ovate, acute, upper side smoothish, lower side pubescent, 2 to 3 inches long, I to I $1 /$ inches wide; lobes of corolla acute, margins hairy; berry the size of a cherry. From Southern Europe and Central Asia.

Diospyros Virginiana, Linnaus. Virginian Persimmon. Leaves lanceshaped or oblong; stamens of the sterile flowers about 16 , of the fertile flowers 8 , imperfect; flowers pale yellow ; fruit about an inch in diameter, edible when well ripened or well frosted. Native tree, 20 to 60 feet high; wood hard and dark.

\section{ELAEAGNACEÆ. Oleaster Family.}

Shrubs or small trees with silvery scaly hairs; flowers small and with the sexes usually separate; corolla none; calyx-tube of the fertile flower enclosing the ovary and forming a berry outside the enclosed true fruit.

Elaagnus. Has the flowers usually perfect.

Elæagnus argentea, Pursh. Silver-Berry. Shrub with "oval silvery leaves and mealy edible berries." From our far Western and Northwestern regions.

Elzagnus hortensis, Marschall. Shrub or tree, often spiny; lanceolate leaves densely white scaly or with stellate hairs on the under surface, greener on upper surface. From the Mediterranean region. The variety angustifolia, Marschall, is also found in some gardens.

Elæagnus longipes, said to be a recent introduction from Japan, is unknown to us.

Elaganus parvifolia, Royle. Silver Moon, False Olive. Has the branchlets white scaly; smallish elliptical leaves on under surface white scaly, with a few brown scales intermixed, upper surface naked, green. Shrub from India and China. Not rare in cultivation, under the name of E. reflexa.

Hippophz. Male and female flowers usually on separate plants ; staminate flowers in deciduous clusters, with a single flower under each scale and 2 small leaf-like organs embracing the stamens; female flowers solitary, with the seed enclosed in a tubular 2-cleft cup.

Hippopha rhamnoides, Linnars. SAllow ThORN, or SEA BuckTHORN. Is a thorny shrub widely distributed in Europe and Asia; leaves linear to lance-shaped; silvery flowers and leaves appearing at the same time; fruit bright orange, edible, though only used extensively by Tartars and other semi-civilized races.

Shepherdia. Has the male and female flowers on different plants, the male with 8 stamens on the disk; "fertile flowers with an urn-shaped 4 -cleft calyx enclusing the ovary, teeth of the disk closing the orifice." 
Shepherdia argentea, Nuttall. Buffalo-Berry. From the far West. Has small oblong leaves, which are green on both sides; scarlet fruit edible, but acid.

Shepherdia Canadensis, Nultall. Canadian Shepherdia. Small shrub which ranges widely over the northern and colder parts of America; leaves I to 2 inches long by half as wide, green on upper and silvery and rusty scaly on under surface ; fruit red, intensely bitter, but sometimes eaten; branchlets also rusty scaly.

\section{ERICACE ÆE. Heath Family.}

A large family of trees and shrubs (few herbs), with simple and usually alternate leaves; flowers mestly regular, and with parts in 4 or 5 ; petals mostly more or less united, sometimes free; stamens as many or twice as many as the lobes of the corolla, anthers generally opening by pores at the apex. Properties various: astringent, sometimes with volatile oils, sometimes poisonous, or again the fruit edible, as in the Blueberries and Huckleberries. Family is divided into a number of well-marked sub-orders, which for our purposes must be thrown together.

Andromeda. Calyx free from the 5-celled ovary, the 4- to 5-toothed or lobed corolla falling after flowering, but the calyx remaining and becoming diy, valvate in the bud. Shrubs.

* Andromeda ligustrina, Muhlenberg. A native shrub, 4 to Io feet high ; obovate leaves thin and green; small globular flowers scaly-pubescent, in branching clusters.

Andromeda Mariana, Linnous. Stagger-Bush. Flowers in "umbel-like clusters," each flower.1/2 inch long, cylindrical oval; leaves thick, shining, veiny; leaf-like sepals fall with the leaves. A native shrub, $\mathbf{I}$ to 4 feet high. The popular name is probably derived from the reputed poisonous action of the leaves on lambs and calves.

Andromeda polifolia, Linnaus. Shrub I to 2 feet high; native of our colder bogs; leaves smooth, entire, glaucous ; margins revolute; corolla nearly globular.

Andromeda speciosa, Michaux. Shrub ranging from North Carolina to Florida; 2 to 4 feet high; the white corolla open bell-shaped; deciduous leaves $I$ to 2 inches long, oval, sparingly toothed; flowers in clusters along the leafless branches of the previous year. This species may be hardy with us. It has the following varieties in the Park: viridis, Duhamel; which is the A. cassinefolia of the gardens; and pulverulenta, Michaux; a white glaucous form.

See Azalea, under Rhododendron.

Possibly some of the hardier tree-forms of Arctostaphylos from the Western coast might be worthy of trial in the Park.

Calluna. Heather. Bell-shaped corolla 4-parted, persisting and drying on the shrub; calyx free from the ovary. 
* Calluna vulgaris, Salisbury. (Erica vulgaris, Linnaus.) This, the twical Scotch Heather, may now be regarded as a native of this continent. Calyx more conspicuous than the corolla; stamens 8, each with a pair of deflexed, horn-like appendages on the back; a low evergreen shrub, with small, crowiled leaves: the rose-colored or whitish flowers crowided on and unually terminating the branches.

Cassandra. Leather-LeAf. Calyx free from the ovary; corolla a cylindrical 5-toothed cup; pod when ripe splitting into 2 layers, of which the inner is in 10 pieces; anthers opening upwardly by tubular beaks.

Cassandra calyculata, Don; is a much-branched, low, native shrub, with oblong leatheıy leaves; common about our colder bogs.

Clethra. White Alder, Sweft Pepper-Bush. Calyx free from the ovary; corolla of 5 separate oblong petals; style slender and 3 -cleft; shrubs or small trees with deciduous leaves; flowers white hoary and terminatıng the branches.

* Clethra acuminata, Michaux. Thin oblong leaves finely serrate; clusters of flowers drooping. Small tree in the mountains from Virginia southward.

Clethra alnifolia, Iinnaus. Obovate leaves entire towards the base but sharply toothed towards the apex; clusters of flowers upright. Shrub along the coast and inland from Maine south. Flowers attractive and fragrant.

Epigza. Ground Laurel, Trailing Arbutus, May-Flower. Calyx free from the ovary; anthers 10, opening lengthwise. Our only speciesrepens, Linnous - is a creeping woody plant, with thick, roughish, oval leaves and very fragrant rose-colored or white flowers, appearing early in spring.

Kalmia. AmERICAN I.AUREL. Calyx free from the ovary; short, broad corolla more or less distinctly 5 -lobed, with 10 pockets, into which the anthers of the recurved stamens are placed. Evergreen shrubs, with thick leaves, usually conspicuous and sometimes poisonous flowers and leaves.

Kalmia angustifolia, Linnaus. LAMBrill, Sheep LaUrel, Wicky. Leaves narruwly oval, opposite or in threes, paler on the under than on the upper surface; the crimson-purple flowers $1 / 4$ to $1 / 2$ inch in diameter; fruiting pedicels recurved. A native shrub, 4 feet high, or under.

Kalmia glauca, Aiton. Native of the colder Northern bogs; I to 2 feet high; leaves oblong or linear, margins revolute, whitish beneath; flowers purple- or lilac-colored, less than $1 / 2$ inch across.

Kalmia latifolia, Linneus. LAUReL, CAl.Ico-Bush. A common native of our mountains and hill-sides; from 2 to Io feet high; leaves lance-ovate, thick, shining, spotted often with brown; flowers $1 / 2$ to $\pi / 4$ of an inch in diameter, white, rose-colored, or crimson, somewhat clammy.

$\mathrm{K}$. pumila and $\mathrm{K}$. rubra appear to be mere garden forms which were invoiced to the Park. 
Ledum. LABRADOR TEA. Calyx free from the ovary; corolla regular, deciduous, petals nearly distinct; pod opening through the partitions; leaves evergreen.

Ledum latifolium, Aiton. Shrub 2 to 3 feet high, ranging widely in North America in the colder parts; leaves broarlly linear to oblong, obtuse, under surface covered with a rusty wool, somewhat fragrant when crushed; stamens 5 to 7 .

Leiophyllum. SAND MYRTLE. Calyx free from the ovary; pod opening through the partitions; petals separate; stamens IO, exserted; anthers opening lengthwise.

Leiophyllum buxifolium, Elliott. Jersey PinK. A spreading, branching, evergreen native shrub, 6 inches to a foot high, with small white flowers in clusters on the ends of the branches. Common in the adjacent pine barrens of New Jersey, whence it is often brought in early spring to the city for sale.

Leucothoe. Calyx free from the ovary; not becoming fleshy after flowering; pod globular but flattened on top, 5-lobed; corolla 5 -toothed; anthers Io, opening by a pore at top, near which each cell has sometimes one or two erect horn-like bodies.

* Leucothoe axillaris, Don; anthers without horn-like projections ; flowers in spike-like clusters from the axils of the thick shining leaves of the previous season; nearly sessile leaves oblong or oval, the fine teeth bristle-pointed. Shrub is 2 to 4 feet high. From the lower parts of Virginia, and may succeed here.

Leucothoe Catesbæi, Gray. (Andromeda Catesbai, Walter.) Anthers without horns; flowers as in the preceding species; leaves with petioles, taperpointed. Shrub 2 to 4 feet high; branches spreading or even pendulous. "Flowers exhaling the unpleasant odor of chestnut blossoms." Mountains of Virginia and southward.

* Leucothoe recurva, Buckley. Anthers with 2 horn-like appendages; branches and flower-clusters recurved-spreading; "leaves lanceolate or ovate, taper-pointed." Low shrub from the mountains of Virginia and southward.

Leucothoe racemosa, Gray. (Andromeda racemosa, Linneus.) Branches and flower-clusters erect; flowers cylindrical; anthers with 4 horn-like appendages; leaves lanceolate or oblong, sharp-pointed. Near the coast, from Massachusetts southward; 4 to 6 feet high.

Menziesia. Calyx free from the ovary; fruit a pod, opening through the partitions; roundish flower 4 -toothed, white or greenish white; stamens 8 , anthers opening by oblique pores at the tips; leaves deciduous. Our single species is :

Menziesia ferruginea, var. globularis, Gray. Leaves thin, oblong, bluntpointed, with a gland-like tip, hairy on upper surface and on margin, lightercolored and hairy on lower surface. Shrub from along the mountains from - Virginia southward. 
Oxydendrum. Sorrel-Trer, Sour.Woon. Tree often 40 feet high,

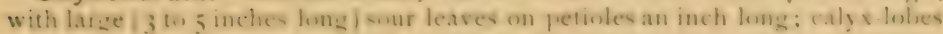
nearly distinct; corolla somewhat hairy, cylindrical-ovate, contracted above; anthers opening liy slif-like pures: white flowers in one silled racemes on the ends of the year's hranches. Our species,-Oxydendrum arboreum, De Candian,-ranges from I'emnslvania and Ohios suthward along the mountains.

Rhododendron (including Azalea and Rhodora). Calyx free from the ovary; pod-valves at maturity separating from the central seed-hearing part; comilia deciluous, reguiar, or irregular, "Iut not comtracted at the oritice;" stamens long and slender, usually twice as many as the lobes of the corolla, hent downward; anthers opening by a round terminal pore and destitute of any horn-like appendage.

We include here simply recognized species, and not the hundred or more beautiful varieties and hybrids which have been produced by cultivation and the names of which appear on the Park invoices.

Azalea section of Rhododendron; has the corolla usually long, funnelform, and sticky outside; 5 stamens.

* Rhododendron arborescens, Torrey. Shrub 3 to ro feet hich ; flowers fragrant, rose-colored, 2 inches or more long, appearing after the leaves, the latter slightly hairy along the margin, greener on the upper than on the lower surface; calyx-lobes narrowly oblong, somewhat large and conspicuous. Pennsylvania southward along the mountains.

Rhododendron calendulaceum, Torrey. Flame-Colored Azalea. Shrub 3 to Io feet high; the bright, large, orange-colored or flaming-red flowers appearing with the leaves, not fragrant; calyx very small and inconspicuous. It ranges from Pennsylvania through the Southern mountains.

Rhododendron flavum, Don. Puntric Azalea. (Azalea Pontica, Linnceus.) Shrub 4 to 6 feet high, from the Levant; varies greatly in its flowers, and hybridizes so freely that it has produced a great number of garden forms. Honey made from this species in its native country is said to be poisonous.

Rhododendron nudiflorum, Torrey. Pinxter Flower. Shrub 4 to 6 feet high, common on our hill-sides; flowers appearing with or hefore the leaves, from a light rose-color to bright purple. The tube is but little longer than the spreading part of the flower. It varies greatly in the wild condition, producing in the South yellow flowers. Hybrid forms are comman in cultivation.

* Rhododendron Rhodora, Don. (Rhodora Canadensis, Linnaus.) A low shrub ranging from Pennsylvania northward in the cold bogs; flowers irregular, purple or rose-color, hardly an inch long (tube very short), appearing before the leaves, which are 1 to 2 inches long.

Rhododendron viscosum, Torrey. Clammy Azalea, White Swamp HoNeYSUCKLE. Shrub 4 to 10 feet high; flowers appearing after the leaves, white or slightly rose-colored; branchlets bristly hairy.

Secting of Rhododendron proper has the cornlla open liell-shaped, htumens 10; leaves thick.

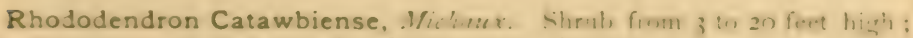
younger parts not scaly-scurfy; flower-stalks glandular hairy; leaves 3 to 5 
inches long by 2 inches wide; flower lilac purple, lobes rounded, $1 \mathrm{I} / 2$ inches high, and somewhat broader; branches erect. High mountains of Virginia and Georgia. This species has been most prolific in new forms under cultivation, especially when crossed with $R$. arboreum from India and with $R$. Ponticum from the Levant.

Rhododendron Indicum, Sreet. (Azalea Indica, Linneus.) Is the common Azalea of the florists. From Japan and China. Common in conservatories.

Rhododendron maximum, Linnceus. Mountain Laurel, Great RhoDODENDRON. Is from 3 to I 5 feet high; branchlets erect, younger parts not scaly-scurfy; flower-stalks sticky hairy; flowers nearly white or rose-colored, greenish-spotted in the throat; leaves 4 to ro inches long. Common in our mountains along the streams.

Rhododendron Ponticum, Linneus. Is a low shrub from the Levant; leaves lanceolate, tapering towards the base; flower purple, open bell-shaped; branches stiff, erect.

Rhododendron punctatum, Andrews. The evergreen leaves lanceolate, not very thick; branches spreading or drooping, 4 to 6 feet high; flowers rosecolored, I inch long, wide-spreading, exceeding the stamens and pistils. Southern mountains.

\section{EUPHORBIACE E. Spurge Family.}

" Plants with mostly milky, acrid juice, and flowers of very various structure," but which usually have the sexes separated (on the same or on different plants). "The ovary and fruit commonly 3 -celled, and with a single or at most a pair of hanging ovules or seeds in each cell." A hard family to limit by description, and, with us being mostly herbaceous, but few come within the limits of this Catalogue. Perhaps no family of plants is characterized by a greater diversity of products: foods, poisons, drugs, caoutchouc, oils, all come from this family.

Buxus. Box. Pod 3-horned and 3-celled, each cell with 2 ovules or seeds; bracted flowers in clusters, usually in the axils of the evergreen, opposite leaves. Wood much used in the arts, especially for finer work.

Buxus Japonica, Muller. JAPAN Box. Readily recognized by the rudimentary ovary, which is as long as the calyx; otherwise much like the common Box. The leaves vary much in color.

Buxus sempervirens, Linnaws. Cомmon Box. Well known by its small, thick, dark-green leaves. Native of the Mediterranean region. Varies much in the color of its leaves, and has the following varieties in cultivation : argentea, Silver-VAriegated Box; aurea, Gol.den-VAriegated Box; myrtifolia, MYrtle-Leaved Box; suffruticosa, DWARF Box; thymifolia, THYME-LEAVED BOX.

Buxus Sinensis, — ? Chinese Box. Is described in the catalogues as a "native of China ; with large foliage, greatly diversified in the various kinds," which are given as-varielies *angustifolia, NARROW-LEAVED CHINESE 
Bux; * latifolia, Broad-Iffaved Chinfse Box; * longifolia, Long-Leaved ChINFse BuX; * rotundifolia, Roundo-Leaved CHINese Box; all of which are said "to be distinct and quite handsome."

Ricinus. PALma ChRISTr. Characterized by the large clusters of flowers, the fertile being above and the staminate below; stamens many, in several bundles; the 3 red styles each 2-parted above and united below; the large prickly 3 -lobed mature pod containing 3 large bug-like seeds. The Park has the species

Ricinus communis, Linncus. Castor-Orl Plant. Which is a large herbaceous annual, but from its conspicuous character is deemed worthy a place here. Its chief beauty is its large foliage (the leaves being $\mathbf{I}$ to 2 feet across), which is orbicular in outline and deeply 7-to 9-cleft. Native of India.

\section{HAMAMELACE⿸尹巳. Witch-Hazel Family.}

"Shrubs or trees with alternate simple leaves, deciduous stipules, small flowers in heads, spikes, or little clusters, the calyx united below with the base of the 2-styled ovary, which forms a hard or woody 2-celled and 2-beaked pod, opening at the summit. Stamens and petals, when present, inserted in the calyx." -Gray.

Corylopsis. Corolla of 5 upwardly dilated petals; filaments of the stamens awl-like; stigmas 2, small and knob-like. We have in the Park but a single species:

Corylopsis spicata, _ _ ? This shrubby plant comes from Japan.

Fothergilla. Calyx-lobes squarely cut at summit; corolla none; the numerous stamens all perfect. The Park has the single species

Fothergilla alnifolia, Linnaus. Shrub from the Southern swamps along the Eastern coast; oval or obovate leaves somewhat hairy on the under surface, toothed towards the apex.

Hamamelis. Witch-Hazel. Parts of the flower in fours, except the ovary, which is single and cleft above into 2 styles; suspended ovules single in each cell.

Hamamelis Virginica, Linneus. A native shruh, 6 to Io feet high; obovate crenately toothed leaves pulescent; yellow flowers, petals long and narrow, appearing in the fall, and fruit remaining undeveloped through the winter. The well-known Pond's Extract comes from this plant, it is said.

Liquidambar. Sweet Gum, Bristed. Male and female flowers separate, but on the same tree. Neither calyx nor corolla; stamens very numerous; styles 2 ; seed-vessels aggregated into a head, seeds wing-angled. Our species is

Liquidambar styraciflua, linneus. Bram hes with corky wings; leaves roundish in outline, but with 5 to 7 sharp-tonthed lolses; juice exuding hardens into a gum. Large tree, common from Philadelphia south. 


\section{HYPERICACEA. Saint John's-Wort Family.}

Plants occasionally woody, with opposite, entire, usually sessile leaves, which are dotted with translucent and blackish spots; stamens many, mostly more or less plainly united into bundles at the base; many-seeded. Family characterized by active, often acrid, properties.

Hypericum. The type genus has the same characters as the family. Of it we have two species to be noted here:

Hypericum Kalmianum, Linnaus. Kalm's St. John's-Wort. Branching shrub; styles 3 ; stamens very numerous; 4-angled stem with crowded, glaucous, oblanceolate leaves. Native, from the Niagara Falls and northern Lake region.

Hypericum prolificum, Linnaus. Shrubby St. John's-Wort. Low, branching shrub, with the branchlets 2-angled; lanceolate oblong leaves narrowed at the base. Of this the variety densiflorum, Gray, is much more branched, crowded with small leaves. Common in the pine barrens of New Jersey, and ranges thence southward.

\section{JUGLANDACEÆ. Walnut and Hickory Family.}

A rather small but important group of trees, with alternate, pinnate leaves; stamens and pistils separate, but on the same tree, the former in scaly, drooping, elongated clusters, the latter single or in a small cluster or spike; calyx adherent to the several-celled but one-seeded or one-ovuled ovary. The group comprises most valuable timber and fuel, and is also accredited with some remedial properties.

Carya. Hickory. Sterile flowers in clustered, hanging catkins, each with 3 to ro short stamens; fertile flowers with no petals; husk of the fruit splitting at maturity more or less completely into 4 valves, from which the nut falls.

Carya alba, N'uttall. Shellbark or Shagbark Hickory. Bud-scales about Io. Tree characterized at once by its long exfoliating strips of bark; leaflets 5, of which the 2 lower are much the smaller; all are taper-pointed; fruit somewhat flattened. This is reckoned the best of all the hickory-nuts. The tree as a timber is large and valuable.

Carya amara, Nuttall. Bittérnut, Swamp Hickory. Bud-scales about 6 ; bark of the tree close and smooth; leaflets 7 to II ; fruit roundish, indistinctly 6-ridged, thin-shelled, and kernel bitter. Timber not the best, though still valuable. A common native tree.

Carya olivzeformis, Nuttall. PeCan Nut. Leaflets I 3 to 15 , tapering to a slender point, somewhat curved, toothed; nut edible, olive- or somewhat cylindrical-shaped. Large tree, native to the rich bottom-lands of Illinois and southward. 
Carya porcina, Nuttall. Picnut, Broom Hickory. Leaflets 5 to 7 ; fruit with hu-k iariably " pear-shaped, oblong, or oral; " thich-chellecl, large nut, oblong, kernel bitter when fairly tasted. Wood valualsle, red at heart; bark rough.

Carya sulcata, Nulfall. Western Shellbark Hickory. Bark as in our shellhark, but leaflets 7 to 9 , quite downy on under surface; the large, thick husk angular above the middle; nut $1 \frac{1}{4}$ to 2 inches $10 n g$, and often angular, pointed at the ends; heart-wood not dark. - From Pennsylvania westward and southward.

Carya tomentosa, Nutlall. Mockfr-Nut, White-Hf.Art Hickory. Bark close, rough, and adherent; pointed leaflets 7 to 9 , when young with a resinous odor; thick, hard-husked fruit globular or nearly so; thick-shelled nut roundish, 4-ridged near the summit, only I inch in diameter. The variety maxima, $\Lambda$ iullall, however, has a thick-husked fruit 2 inches or more in diameter. This species is common, and furnishes a valuable wood for certain purposes.

Juglans. Walnut. Sterile flowers in single (not clustered) catkins; stamens 12 to 40 ; fertile flowers with a 4 -cleft calyx and 4 small green petals; fruit-husk not splitting as in the hickory; leaves, bark, and shoots often strongscented.

Juglans cinerea, Linneus. BUtTERnt. Native tree of middling size; bark smooth and white; young branches sticky hairy; stamens about 12; nut 2 inches long by about I to I / inches through, with sharp, rough longitudinal ridges. Timber of no great value.

Juglans Mandschurica, Maximorvicz. Manchoorian WaLnut. Tree from the Amoor River region; stamens about 8; fruit as in the preceding, except that the ridges of the nut are thicker.

Juglans nigra, Linneus. BLACK WALNUT. Young branchlets hairy but not sticky; nut round, or nearly so, ridged, lut not deeply or sharply. One of the largest and most valuable of all our native trees.

Juglans pendula, —? Found in the invoices, but otherwise unknown to us.

Juglans regia, Linneus. English WALnut. Tree widely distributed over Southern and Central Asia, and not a native of England. Oval leaflets entire and nearly smooth; husk of the fruit brittle and readily separating from the roundish, wrinkled, light-brown nut when ripe. The following varieties are in the Park: laciniata, Cas. De Candolle; with the 5 to 6 pairs of leaflets much divided; nut attenuated at the apex. monophylla, Cas. De Candolle; has not more than a pair of entire-margined leaflets to the leaf. praparturiens, Cas. De Candolle; 4 pairs of sessile, ovate, entire, leathery leaflets.

Juglans rupestris, Engelmunn. Is a large shrub or small tree from New Mexico, characterized by its numerous, 17 to 23 , narrow, long-pointed leaflets, and its small fruit, the nut of which is not more than $1 / 2$ inch in diameter.

Pterocarya. Differs from Carya chieev in its fruit, which is $\mathbf{2}$-winged and does nut open at maturity. 
Pterocarya fraxinifolia, Spach. (P. Caucrsica, C. A. Meyer.) Leaves with 12 pairs of leaflets, which are toothed and on the under surface along the primary veins slightly hairy. Tree from the Caucasian region. There are besides in the Park invoices two other less important names,-i.e., lavigata and Sinensis.

\section{LAURACE $\mathbb{E}$. Laurel Family.}

This is the true Laurel Family: our Laurel belongs to the Ericacee, or Heath Family. Trees or shrubs abounding in spices and aromatics; leaves simple, alternate, usually with transparent dots; flowers (calyx only) regular, sepals 4 to 6 , not united to the ovary, in 2 series; anthers opening by uplifted valves; ovary I-celled, with a single hanging ovule, which (ovary) matures into a berry or a stone fruit. Cinnamon, Cassia bark, and Camphor are among the products of the foreign species of this order.

Lindera. Shrubs with the male and female flowers usually on different individual bushes, appearing before the leaves in close clusters along the branches; sterile flowers with 9 stamens, of which the 3 inner ones have the filaments lobed and glandular at base; fertile flowers with a globular ovary surrounded by rudimentary stamens; calyx bright yellow; fruit red, oblong or oval.

Lindera Benzoin, Meisner. SpICe-Bush, Benjamin Bush. Is a common native shrub, 6 to ro feet high; leaves downy (at first) on lower surface.

* Lindera melissæfolia, Blume. Shrub 2 to 3 feet high; leaves thick, silky on both surfaces. Native from North Carolina southward.

Persea. RED BAy. Flowers perfect; stamens 9, with anthers, the 3 outer ones turned outwards and the others inwards; 3 glands form a circle inside all these; anthers each opening with 4 valves,-i.e., 2 above and 2 below.

Persea Carolinensis, Nees. Carolina Red Bay. Is a small tree growing from Delaware south; leaves oblong; berries blue on a red stalk.

Sassafras. Male and female flowers almost exclusively on different trees, greenish yellow; male with 9 stamens inserted in 3 rows, the innermost set with a pair of stalked glands at base of each; anthers 4-celled, and each opening by 4 valves; female flowers with 6 rudiments of stamens around the ovary; mature fruit blue.

Sassafras officinale, Nees. SASSAfras. Ovate leaves entire or variously 3 -lobed; young branches somewhat warty, green or yellowish green; bark aromatic, that of the root especially when growing in rocky places, a popular source of a domestic supposed remedial tea. Common in our woods, and a native of the Park.

Tetranthera. Flowers with the pistils and stamens almost entirely on different trees; sterile flowers with 9 stamens in 3 rows, fertile ones with 12 or more rudimentary stamens; mature fruit red.

Tetranthera geniculata, Nees. Has yellow flowers coming before the leaves, which are oblong and hairy on the midrib below; branchlets zigzag. From the swamps of Virginia and southward. 


\section{LEGUMINOSA. Pulse or Bean Family.}

Flowers mostly irregular,-i.e, with a large roundish upper, a scythe-shaped smaller lower, and 2 usually unsymmetrical side-petals; fruit a single, more or less I-sided, continuous or jointed porl; stamens 10, 9 more or less combined and I free, or all separate; leaves alternate, often compound, leaflets entire; stipules nearly always present.

A large, willely-diffused, and most important family, furnishing timber, fibres, gums, dyes, and other articles of economic value. In it we have peas, beans, lentils, kidney-beans, lupins, clover, liquorice, tragacanth, and indigo. Among the poisons it produces Cytisus Laburnum, Physostigma venenosum (the African Ordeal hean), and in our own country the Sophora speciosa, which furnishes an alkaloid that acts in the same manner as the Physostigma does, Besides these, there are, in the West, the so-called Loco plants, which year by year destroy great numbers of sheep and horses. These are supposed to be Oxytropis Lamberti and two or three species of Astragalus.

Albizzia. Has small regular flowers crowded into heads along the stem ; pale rose-color; 5 petals united into a funnel-shaped lobed cup, from which the long stamens protrude; pod flat and thin; leaves twice pinnate.

Albizzia Julibrissin, Durazzini. SIlk-Flower, Silk-TreE. (Acacia Fulibrissin, Willdenow.) The popular name derived from the long, shining tufts of stamens, which give a silky appearance to the tree; leaflets very numerous, halved in appearance: pod broadly linear, 5 to 6 inches long, contracted between the seeds. Native of Asia, but partly naturalized in the Gulf States.

Amorpha. False Ixdigo. Shrubs with leaves composed of many leaflets; flowers with a single petal (the upper one), which is wrapped around the 10 nearly separate stamens, clustered in dense spike-like heads.

* Amorpha canescens, Nuttall. Lead-Plant. Shrubby at base, I to 3 feet high, white downy all over; leaves of 10 to 25 pairs of small, oval, nearly se-sile leaflets; small, late flowers violet purple; pods with a single seed. Grows from Michigan southwestward. Its presence is regarded popularly as an indication of lead.

Amorpha fruticosa, Linneus. FAlse INvigo. Shrub of middle size; younger hranchlets and leaflets slightly pubescent; leaves of 5 to 13 pairs of oblong ( $3 / 4$ to I $1 / 2$ inches long) leaflets; flowers early, violet-colored; pods generally 2 -seeded. Pennsylvania, westward and southward. A. fragrans, Sweel, is a variety of the above, and is common in gardens.

* Amorpha herbacea, Walter. Shrub 2 to 4 feet high ; branches red or purple; leaves of 15 to 35 smallish-dotted leaflets; pod I-seeded; flowers white or blue. Native of pine barrens from Florida to North Carolina.

Caragana. PEA-TREe. Flower irregular; stamens 10, of these 9 are united at hase and $\mathbf{I}$ is free: pod linear, several-seeded; leaves clustered, of several pairs of leaflets (instead of the end leaflet there is frequently a minute spiny point); flowers on short stalks, not more than 3 together; lower petal (keel) nearly straight. 
Caragana arborescens, Lambert. Siberian PEA. Large shrub or small tree, with 4 to 6 pairs of leaflets (and a soft tip instead of the end leaflet), which are oblong and somewhat downy; flowers early, single, yellow. Native of Siberia.

Cercis. RED-Bud, JUDAS-TrEe. Leaves simple; irregular flower, appearing to be (but not truly) papilionaceous, coming before the leaves, in conspicuous red clusters; thin flat pod narrow, more or less winged on one sirle. The name Judas-tree comes from the old English idea that it was on this the traitor hanged himself.

Cercis Canadensis, Linnous. American Red-Bud. Tree $20 \mathrm{feet} \mathrm{high,}$ covered in spring with a profusion of bright-red or somewhat purple clustered flowers; leaves heart-shaped, pointed. Native in the Park.

Cercis Japonica (?). JAPAN RED-BUD. A recent introduction from Japan; said to be hardy, and to have bright rose-colored flowers which are larger than those of our native species.

Cercis Siliquastrum, Linnous. European Red-Bud. Shrubby in the North. Has large flowers, which are raised on a stalk out of the calyx, and broad, almost kidney-shaped leaves; flowers bright rose-colored or sometimes white. From Europe.

Cladrastis. Tree with yellow wood and white irregular flowers, which hang in clusters from the ends of the branches; stamens barely united at base; bases of the leaf-stalks hollow and covering buds for the ensuing year.

Cladrastis tinctoria, Rafinesque. Yellow Woon. (Virgilia lutea, Michaux the younger.) A beautiful small tree, with smooth bark; leaves of 7 to II oval leaflets; stipules none; keel-petals separate. Native of the western slope of the Southern Alleghanies.

Colutea. Bladder Senna. Shrubs with irregular flowers, not prickly; upper petal spreading, lower petal strongly curved upwards and inwards on Jong united claws; the inflated bladder-like pod raised on a stalk clear of the calyx, several-seeded, and somewhat "flattened on the seed-bearing side."

Colutea arborescens, Linnous. Common Bladder Senna. Leaves with 7 to II oval or oblong leaflets which are somewhat notched or squarely cut at the apex; flowers yellow, 5 to 10 in a loose bunch; the thin inflated pod large. Shrub from Europe.

Colutea cruenta, Aiton. Oriental Biadder Senna. Leaves with obovate somewhat glaucous leaflets which are notched at the end; flowers yellowish brown or reddish, 4 to 5 in a loose cluster; pod opens before ripening by a slit. Native of Southern Europe, and barely hardy here.

Cytisus. "Leaves of $\mathbf{I}$ or 3 leaflets, or the green branches sometimes leafless; stipules minute or wanting; calyx 2-lipped or 5-toothed. Keel straight or somewhat curved, blunt, soon turned down. Style incurved, or even curled up after the flower opens. Pod flat. Seeds with a fleshy or scale-like appendage at the scar. Low shrubby plants."-Gray. 
Cytisus albus, Link. White Broom. Slender branches round; leaves simple or of 3 sessile, linear ohlong leatlets; flower-clusters in long racemes; very hairy pod 2-seeded. Native of Portugal.

Cytisus capitata, Facquin. Stems erect, branchlets hispid; leaflets hairy, ovate, elliptical; the numerous head-like clusters of flowers at the ends of the branches; calyx and legumes rough hairy. Native of Suuthern and Central Europe.

Cytisus scoparius, Link. SсотсH BRoом. The angular branches nearly smooth; leaves compound, of 3 leaflets, or the highest ones simple; flowers solitary, on a little foot-stalk in the axils of the leaves; seed-pod hairy along the margin. Native of the sandy and woody parts of Western Europe. "Broom tops in large doses are emetic and purgatuve, in small doses they are diuretic and mildly purgative."

Desmodium. TICK-Treforl. Flowers irregular, 9 of the stamens more or less united at base; pod flat-jointed, narrowed at the joints and separating at them when mature, usually provided with hooked hairs by which they attach themselves to passing objects.

Desmodium racemosum, De Candolle. Is an erect, somewhat shrubby plant from Japan; the smooth branches angled; leaves with 3 ovate acute leaflets which are slightly hairy on the under surface; pod in this species has not the usual hooked hairs.

Genista. Flowers irregular, 9 stamens more or less united; leaves simple; lowest petal nearly straight, reflexed when the flower is fully open; pod flat.

Genista tinctoria, Linnaus. DYER's GrEen-IVEED. Is a low shrub, with sharp-angled erect branches; not thorny; leaves lance-shaped; flowers yellow, $1 / 2$ inch long, in moderately close clusters on the ends of the branches. Naturalized from Europe.

Gleditschia. HONEY-Locust. Flowers somewhat irregular, perfect or imperfect, in narrow clusters, stamens 3 to 10 , separate; petals much alike, all narrow and spreading; pod flat, with one to several flat seeds.

Gleditschia Caspica, Desfontaines. Caspian Honey-Locust. The 3 cleft thorns flat, slencler; leaves often bipinnate, leaflets obtuse, elliptical lanceolate. Frum the Caspian Sea region.

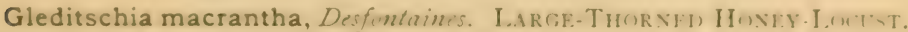
Heavy thorns with many conical branches; main stem thorny; leaflets lanceshaped, nearly an inch long, toothed, somewhat stiff; pod large, thick, and containing a bitter pulp. Native country unknown.

Gleditschia monosperma, Waller. OnE-Sefnen Honey-Locust. A small Iree, growing from Illinois south and southwestward, with slender thorns and oval rather obtuse leaflets, and one-seeded ovate pulpless pods.

Gleditschia Sinensis, Lambert. ChINese HoNey-Locust. (Gleditschio horrida, Willdenono.) With heavy thorns, and obtuse ovate elliptical leaflets; pod elongated and cumpressed. Native of China. 
Gleditschia triacanthos, Linnaus. Common Honey-Locust. Large native tree, ranging from this State south. Thorns often much branched, somewhat flat at base; leaflets small lanceolate to oblong, slighily toothed; pods Io to is inches long, flat curved and often twisted, containing a sweetish pulp. Tree sometimes utilized in hedges.

Gymnocladus. Tall tree, without thorns; leaves large, compound; flowers white or nearly so, perfect or imperfect, hanging in clusters from the ends of the year's branches; stamens ro, all distinct; pod very hard, flattish, and oblong in outline, with a little sweetish pulp and several hard thick seeds, $1 / 2$ inch or more in diameter.

Gymnocladus Canadensis, Lambert. Kentucky Coffee-Tree. Tree large and valuable both for ornament and its timber. Ranging from Pennsylvania southward. Pod 6 to ro inches long and 2 inches across.

Laburnum. "Leaves of 3 leaflets; stipules inconspicuous or wanting. Calyx with 2 short lips, the upper lip notched, keel incurved, not pointed, ovary and flat pod somewhat stalked in the calyx; seeds naked at the scar. Trees or shrubs with golden-yellow flowers in long hanging racemes."-Gray. The following species of Laburnum have at one time or another been placed under Cytisus: see page 60.

Laburnum Alpinum, Grisebach. Alpine Laburnum. (Cytisus Alpinus, Miller.) A smooth small tree, with round branches and ovate-lanceolate leaflets which are round at base; fruit-stalks and calyx slightly hirsute; smooth few-seeded pod with a distinct margin. Native of the Alps and Apennines in Europe. Has produced a number of varieties under cultivation. Wood hard and of some value.

Laburnum grandiflorum, Grisebach. LARGE-FLOWERED LABURNuM. (Cytisus grandiflorus, De Candolle.) Angular branches often smooth; clustered leaves either single or of 3 ovate-lanceolate leaflets; flowers on little stalks, either single or in pairs; legumes woolly. Native of Portugal.

Laburnum vulgare, Grisebach. Golden Chain, Common Laburnum, BeAN TrefoIl-TREE. (Cytisus Laburnum, Linnaus.) Low-branching tree with smooth green bark; leaves of 3 thin, grayish, oval, bluntly-tipped leaflets which are $1 / 2$ inch to 2 inches long; pod one-seeded, one side thicker, somewhat curved, and tapering to a slender base. It should be remembered that this attractive species produces seeds which are a violent emetic poison. Native of Europe. Wood hard and of some value. Under cultivation this tree has developed a number of well-marked varieties.

Robinia. Locust-TREe. Flowers irregular, handsome, white or rosecolored, hanging in long clusters; 9 stamens more or less united at base; leaves compound, leaflets netted-veined; leaf-stalks hollowed out at base and covering the buds for the next season; young pod stalked in the calyx, mature pod thin, flat, several-seeded, and with a narrow border on the seed-bearing side. Trees or shrubs often with prickles or spines in place of stipules at the base of the leaf foot-stalk.

Robinia hispida, Linneus. Bristly Locust, Rose Acacia. Shrub 3 to 8 feet high, with leaf-stalks and young branches covered with spreading bristly hairs; leaflets $3 / 4$ inch to $1 \mathrm{I} / 2$ inches long, obovate or oval to nearly round, 
conspicuously bristle-tipped at the apex; the scentless flowers large and deeply rose-colored; pods rongh glandular hairy. Common in cultivation, but a native of the Southern Alleghanies.

Robinia Pseudacacia, Linncus. Common Locust. Middle-sized tree, with yellow, elastic, durable wood which in some of the arts is of great value. Leaves smooth, oblong, paler on under than on upper surface; fragrant flowers white or cream-colored. A common native on the rocky sides of our Alleghanies.

Robinia viscosa, I"ntenat. Small tree, with branchlets and leaf-stalks clammy and glandular; flowers scentless, somewhat tinged with rose-color, in short, compact clusters; pods rough, sticky. Native of Virginia and suuthward.

Sophora. Trees or shrubs (seldom herbs) with irregular flowers; stamens nearly or quite separated; pod not jointed, lsut often much cuntracted around the seeds; leaves pinnate; fiowers cream-colored in

Sophora Japonica, Linnaus. JAPAN SOPHORA. Tree from Japan, 40 to 50 feet high, with leaflets (I I to 13 to each leaf) oval, smooth, and acute; flowers in somewhat dense clusters. From these flowers a dye used to color the dresses of the mandarins is made, and all parts of the tree are reputed to possess purgative properties. A species from the Mexican boundary- $\mathbf{S}$. secundiflora, Lagasca-produces beans which araknown to be intoxicating in very small doses and violently poisonous in larger ones. An alkaloid (Sophoria) has been discovered in them by Dr. H. C. Wood.

Wistaria. ${ }^{T}$ Woody climbing vines, with large drooping clusters of conspicuous blue irregular flowers; calyx with shorter teeth on the upper side; pod thick, knobby, many-seeded, and opening late.

Wistaria frutescens, De Candolle. Native along the streams from West Virginia to Illinois and southward; side-petals of the flower with a short ear on one side at base and an awl-shaped one on the other.

Wistaria Sinensis, De Candolle. Chinese Wistaria. Wing- (or side-) petals with a small ear-like appendage on one side of the base only. A taller climber and more profuse bloomer than our native species.

There are other species and a host of varieties in cultivation, but all of less note.

\section{LYTHRACE $Æ$. Loosestrife Family.}

Characterized by the calyx enclosing though not united to the ovary, which is 1 - to 4-celled and many-seeded; petals and stamens inserted on the caly $x$, the latter lower down; leaves simple, not pellucid dotted; anthers opening lengthwise. Not remarkable for any special properties: some of is representatives are astringent, and one yields the dye "henna" with which the Arabian women color their nails pink.

1 The orthography of this name, as given by Nuttall, who founded the genus, is Wisteria I ut, as it is intended 10 commemorate the late Dr. Caspar Wistar, of Philadeluhia, it is obvious that the spelling (Mistaria) above given, and adopted by the best authoritics, is the better one. 
Lagerstromia. Flower of a 6-lobed calyx and 6 wavy long-clawed petals; the numerous stamens are long and slender, rising from the bottom of the calyx, the 6 outermost ones larger than the others; oblong, thick, manyseeded pod 3- to 6-celled.

Lagerstrœmia Indica, Linneus. Crape Myrtle. A small tree from the East Indies. Scarcely hardy here, but enduring the winters on the Eastern Shore of Maryland. Flowers very attractive from their rose- or flesh-colored masses.

\section{MAGNOLIACERE. Magnolia Family.}

Trees or shrubs; bark aromatic and bitter; leaves usually large, with deciduous stipules and mostly entire; flowers generally large, solitary, parts in 3 , calyx and corolla more or less alike; pistils, and usually the stamens, numerous on a long central axis; seeds one or two to each carpel. Most common in North America, India, China, and Japan.

Liriodendron. TUlip-Tree. "Sepals 3, reflexed; corolla bell-shaped, of 6 broad greenish-orange petals;" long stamens with large anthers, which open outwardly; carpels (the fruit-scales) with a wing-like style and a small, thicker seed-end, which never opens.

Liriodendron Tulipifera, Linneeus. Tulip-Tree, Yellow Poplar, Whitewoon. A noble native tree, of great use in the arts; leaves 3-lobed, the terminal lobe being cut off nearly square; fruit-cone $21 / 2$ to $3 \frac{1}{2}$ inches long.

Magnolia. Sepals 3, petals 6 or 9; stamens short, and anthers opening inwardly; carpels fleshy, and red or rose-colored in fruit, producing a cone, when mature opening on the back, allowing the red seeds to fall out, where they often hang suspended by the long threads.

Magnolia acuminata, Linnous. Cucumber-Tree. Native tree of middle size; the yellowish-green flowers, 3 inches across, appearing in May or June; thin leaves pointed at each end and somewhat downy on the under surface. The cucumber-like fruit used in whisky as a tonic and antimalarial remedy in the olden time.

Magnolia Campbellii, Hooker. From India. This is distinguished from the other species by having the bud-scales acting as stipules, and from them leaves are developed. It is a large tree, reaching in its home 150 feet in height.

Magnolia conspicua, Salisbury. This is the Yulan of the Chinese. Hardy with us, save that its large white flowers are sometimes killed by spring frosts. The obovate pointed leaves (young ones downy) appear after the flowers. A most profuse bloomer. Magnolia Thurberi of the gardens is probably a form of this.

Magnolia cordata, Michaux. Yellow Cucumber Magnolia. Hardy, though from the Southern States; leaves ovate and flowers lemon-colored. Small tree.

Magnolia Fraseri, Walter. EAR-Leaved Magnolia. (Magnolia auriculata, Lambert.) A middle-sized tree growing from Virginia south; hardy 
here; leave profluceal into ear-like lolues at base; a foot long; fluwers white, fet.uls somewhat narrowed into a claw.

Magnolia glauca, Linnaus. SWEFt BAY. A small native tree ranging from Massachuselts south in the swamps along the coast; leaves oval or oblung, thick, whitish on the under surface; the white or cream-colored fragrant flowers 2 to 3 inches in diameter. The flowers are known to produce in some people a species of hay fever. It has develuped a variety with longer leaves,-i.e., longifolia.

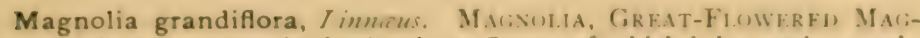
NoulA. Tree evergreen in the Southern States, of which it is a native; only half hardy here. Leathery, oblong leaves 6 inches to a foot long, somewhat rusty on the under surface. The fragrant flowers white, 9 inches across.

Magnolia Kobus, De Candolle. (Magnolia gracilis, Salisbury.) A small, slender-growing tree from Japan, with flowers cup-shaped, dark purple without and white within; leaves ohovate, pointed at either end, young ones pubescent, older ones smooth, appearing after the flowers.

Magnolia macrophylla, Michaux. Large-Leaved Magnolia. This is a small tree, with leaves 2 to 3 feet long, oblong, heart-shaped at base, white on under surface; flowers white, rather strong-scented, a foot across, oblong petals often with a red spot at base. Southern States; but hardy here.

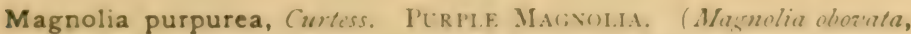
Thunberg.) Hardy Japanese shrub, 4 to 8 feet high; flowers purple outside, whitish inside, appearing before the oval dark-green leaves.

Magnolia Umbrella, Lambert. Umbreli.a Magnolia. (Magnolia tripetala, Linncus.) Small tree, with the large leaves crowded and spreading from the ends of the branches like an unbrella, and surrounding a flower which is 6 inches or more acruss.

The Park has also the following hybrids: $M$. Alexandrina; $M$. Lenne; $M$. Norbertiana; M. Soulangiana; M. speciosa; and M. 7 hompsoniana.

Trochodendron. A peculiar Japanese genus, of a single species:

Trochodendron aralıoides, Sicbold and Zuccarini. Tree with neither sepals nor petals; stamens many; carpels more or less united, berry-like and inclehiscent: leaves are arranged in remote whorls and last 3 years, thick in texture and rhomb-shaped. Flower-clusters terminate the branches.

\section{MALVACEA. Mallow or Hollyhock Family.}

Readily known by the stamens being united around the style; anthers kidney-shaped and $\mathbf{I}$-celled; calyx-lobes touching eilge to edge, and petals with edlge overlapping edge in the bud. The order has mucilaginous and demulcent properties, and furnishes the following (among other) fibres: Parisium elatums gives Cuba hazt; Hibiscus cannabinus gives Indian Hemp; Gossypium furnishes the various kinds of Cotton.

Hibiscus. Anthers on outside of, not on the top of, the stamineal tube; ovary 5-celled, cells many-seeded; stigmas 5, small and knob tike. The Park 
has a single species,-i.e, Hibiscus Syriacus, Linnaus. TREe Hibiscus or Shrubby AltheA of the gardeners. Shrub 6 to 8 feet high, with leaves wedge-ovate, 3 -lohed; variously-colored flowers 3 inches across (often double), situated in the axils of the leaves. There are about Io varieties of this species in the Park.

\section{MYRICACE Æ. Sweet Gale Family.}

Low shrubs; leaves resinous dotted and often fragrant ; flowers with pistils and stamens either on different plants or on different parts of the same plant, always in scaly clusters, without either true calyx or any corolla; fruit a Iseeded fleshy or dry stone fruit, often covered with wax. Family characterized by aromatic, tonic, and astringent properties.

Comptonia. SweEt FERn. Sexes on different parts of the same plant; the staminate clusters in cylinclrical, the pi-tillate in round bur-like heads $1 / 2$ to $3 / 4$ of an inch in diameter; nut surrounded by long-pointed scales.

Comptonia asplenifolia, Aiton: Has linear or lanceolate, downy, doubletoothed, aromatic leaves. Native on our barren hills. Infusion of the leaves a domestic remedy in dysentery.

Myrica. Bayberry, Wax Myrtle. Stamens and pistils usually on different plants; the flower-clusters from lateral scaly buds; 2 to 8 stamens to a male flower; fertile flowers with an ovary having 2 slender stigmas and surrounded by a few small scales.

Myrica cerifera, Linnaus. Shrub 2 to 8 feet high, with fragrant, mostly entire, lanceolate leaves, the hard small nuts covered with wax and looking like berries. Most common along the Atlantic coast.

Myrica Gale, Linncus. Sweet Gat.e. Leaves somewhat wedge-shaped, notched towards the apex; small nuts crowded and furnished with wing-like scales.

\section{OLEACEA. Olive Family.}

Corolla united in a more or less elongated cup, or nearly or quite separated ; stamens fewer than the 4 to 5 lobes or parts of the corolla. Free ovary usually 2-celled, with a pair of ovules in each cell. Trees or shrubs with "bitter tonic and astringent properties." Some, as the olive, yield a fixed oil.

Chionanthus. The white flower with 4 very long narrow petals; stamens 2 , short, barely adherent to the lobes of the corolla; fruit round and fleshy, with a I-celled, I-seeded stone.

Chionanthus Virginicus, Linnaus. Fringe-Tree. Grows from Pennsylvania south, and is a most strikingly handsome tree in cultivation.

* Forestiera acuminata, Poiret. Is a low shrub, with the sexes on different individuals; flowers crowded in scaly huds from the axils of the last year's leaves; corolla absent, and calyx falls early. Native of the river-banks from Illinois southward. 
Forsythia. Low hardy shrubs from China and Japan, with bright-yellow, conspicuous flowers which appear in early spring before the leaves; flowers leell-shaped, 4-lobed, stamens 2, ovary with several seeds in each of the 2 cells.

Forsythia suspensa, $l a h l$. Branches weak, needing support; ovate leaves thin, dull green.

Forsythia viridissima, — ? Shrub with erect, strong branches; leaves thickish, lanceolate, bright green.

Fraxinus. Calyx small, or wanting entirely; petals 2 to 4 , or even none; fruit 1 -seeded, with a wing $3 / 4$ of an inch to 1 inch or more long; leaves simply compound.

Fraxinus Americana, Linnans. White Ash. Petals none and calyx small; fruit round cylindrical at base, narrowly winged from the apex only; leaflets 5 to 9 , oblong, pointed, pale or somewhat downy on the under surface; young shoots and leaf-stalks smooth. A large, valuable native tree, most common in low grounds. The Park has also varieties aucubæfolia, with gold-spotted foliage, juglandifolia, and lutea. It still requires varieties * pannosa and * punctata, the furmer with hairy shoots and large sharppointed leaves, and the latter with yellow-spotted foliage.

Fraxinus excelsior, Linneus. English or European Ash. Flowers some unisexual, others hermaphrodite; petals none and calyx small; leaves bright green, of 5 to 6 pairs of oblong or lance-shaped, toothed leaflets; fruit flat and narrowly oblong. From Eurupe, where it attains a height of from 60 to 80 feet. A tree of great value, and one also to which an infinite number of uses has been ascribed by the superstitions of the past. It has long been cultivated, and has produced a large number of varieties, among which the most important are-aurea, GOLDEN-BARKED; heterophylla; Jaspidea, with striped bark; atrovirens, with dark-green foliage; angustifolia, WıLLow-LEAved AsH, with light-green foliage; monophylla, Single-LeAved AsH; pendula, with drooping branches and small leaves. The Park has the above varieties. It yet requires * myrtifolia, a small tree with small leaves, as well as other less important forms.

Fraxinus Elonza Japonica is by some regarded as a form of F. excelsior. It comes from Japan, huwever, and has long, drooping branches and small, light-green leaves.

Fraxinus Ornus, Linnarus. Flowering Ash. (Ornus Europaa, Persoon.) Tree 20 to 30 feet high, from Southern Europe; barely hardy here. The manua of commerce is derived from this tree. Some of the flowers are unisexual, others are hermaphrodite, with 2 or 4 small, greenish, fringe-like petals; leaves with 5 to 9 small lanceclate or oblung leaflets; winged fruit linear oblong.

Fraxinus pubescens, Lambert. . RED AsH. A rather small native tree, of no great value; flowers without petals, and the male and female flowers on difierent trees usually; fruit linear to oblong, seed-bearing part somewhat 2 edged; leaflets 7 to 9, pale, entire or nearly so; young shoots and leal-stalks soli downy. 
Fraxinus quadrangulata, Michanx. BLUE AsH. Large native tree, growing from Ohio to Wisconsin and southward; furnishing good timber; calyx remaining on the base of the flat fruit, which is oblong and winged all around; leaflets 4 to 7 , ovate and veiny.

Fraxinus sambucifolia, Lambert. BlAcK or WATER Ash. A small native tree, with tough wood which is used in basket-making; fertile flowers without a calyx; wing extending clear around the seed of the narrowly elliptical fruit; leaflets 7 to $I I$, sessile.

* Fraxinus viridis, Michaux the younger. Green Ash. A middlesized native tree, with 5 to 9 ovate bright-green leaflets which are toothed towards the apex; acutely 2-wing-margined fruit tapering upwards gradually into the narrow wing.

The group of Ash Trees is among the most troublesome of any named in this list. The numerous varieties, and the reckless use of old and useless coining of new names, combine to produce much confusion in this genus.

Ligustrum. PRIVET or PRIM. Short funnel-form corolla, white or yellowish white, lobes spreading obtuse; berry black, with from I to 4 seeds; leaves thick, short-petioled, and entire. The common form, introduced here from Europe, is

Ligustrum vulgare, Linnous. Its chief value is in making good and ornamental hedges. There is also another species, L. Japonicum, Thunberg, from Japan, which is characterized by broader leaves and larger and looser masses of flowers. It is not hardy here. L. coriaceum is a mere garden form.

Olea. Olıve. Short corolla 4-cleft, with spreading lobes; fruit I celled, I-seeded, stone hard.

Olea illicifolia, — ? is described as a very elegant evergreen. Hardy Japanese shrub, with holly-like leaves.

Syringa. Lilac. Shrubs with flowers which are tubular below and spreading above; fruit a 4 -seeded pod, flattened at right angles to the internal partitions; seeds with a narrow border or margin. The large clusters of fragrant flowers constitute the charm of these plants.

Syringa Josikæa, Facquin. JosıkA's LILAC. Shrub 6 to 8 feet high, native of Transylvania; leaves elliptical-lanceolate, wrinkled, not hairy, white on the lower surface; flowers bluish purple.

Syringa Persica, Linnœus. Persian Lilac. Leaves narrowly ovate; flowers pale lilac purple, or often pure white; border of corolla flat; flowerclusters not so compact as in the common species.

Syringa vulgaris, Linnaus. Common Lilac. Shrub from Eastern Europe or Persia ; leaves ovate, with heart-shaped base; flower-clusters large and compact, flowers "lilac;" pale violet or even white lobes morlerately spreading. It has produced a host of beautiful varieties, now in common cultivation in gardens. 


\section{PLATANACEAE. Plane-Tree Family.}

Trees: leaves altemate, decply divergently lohed; flowers in ghobular heads, male and female on the same plant, but not in the same heads; calyx and corolla both wanting: male flowers of many stamens mixed with small scales; pistillate flowers of upwardly enlarged ovaries, and mixed with the scales.

Platanus occidentalis, limnaus. American Plane, Sycamore, ButToxwoon. Large, well-known native tree along our river-banks. Bark white, separating in thin sheets; leaves squarely cut or heart-shaped at base, lobes short but sharp, scurfy downy on under surface, remaining so until old; fertile heads solitary, an inch in diameter when mature. Wood valuable for certain purposes.

Platanus orientalis, Linneus. ORIental Plane. Distinguished from the preceding by its leaves heing somewhat more deeply divided, becoming smooth sooner, and by the heads of fruit and flowers being larger.

\section{RHAMNACE Æ. Buckthorn Family.}

Shrubs or trees with simple and usually alternate leaves; stamens of same number as the petals and opposite to them, inserted on the disk lining the bottom of the calyx; ovary with a single young seed in each of its 2 to 5 cells. The family has bitter astringent and cathartic properties.

Berchemia. SUPPLE-JACK. Wnody twiners climbing over neighboring hushes and trees; disk almost filling the bottom of the calyx; ovary maturing into a 2 -celled stone fruit with a thin parple pulp; calyx free from the ovary.

Berchemia volubilis, De Candolle. A common plant in the Southern States; leaves oblong, feather-veined; flowers greenish white, in small clusters terminating the young branchlets.

Ceanothus. NEw Jersey TEA, RED Root. Disk allhering to the calyx; petals small, 5, somewhat hooded or incurved at the summit, spreading, on slender claws; ovary 3 -celled, maturing into a hardish 3 -seeded pod; flowers white.

Ceanothus Americanus, Linnaus. This species strictly is the NEw JERSEY TEA, and was during the Revolution used as a substitute for the imported article. It is a shrub 1 to 2 feet high; root dark red; leaves ovate, distinctly 3 -veined, pointed, finely toothed; flowers in summer crowded into a somewhat dense cluster on the ends of the branches.

Ceanothus ovalis, Bigelow. Oval-Leaved Ceanothus. Native on dry rocks from Vermont to Wiscunsin and westward; smaller than the preceding, with oval leaves acute at each end, somewhat larger flowers, and blooming in spring.

Frangula. Alder Becktuorn. Our single species, F. Caroliniana, Gray, is a shrub or small tree without thorns; flowers hermaphrodite, calyx- 
lobes, petals, and stamens nearly always 5 ; "leaves with nearly straight, parallel veins;" seeds convex on the back. This species grows in wet places from New Jersey south, and has rather large oblong leaves, with the flowers single or in small clusters in the axils; fruit black, 3 -seeded. By most authorities this genus is now united with

Rhamnus. BUCKTHORN. Differs from the above mainly in the seeds, which are grooved or concave on the hack; leaves feather-veined. Flowers greenish white and with the sexes usually separate.

Rhamnus alnifolius, L'Héritier. Alder-Leaven BuCkthorn. A low native shrub, with oval, sharp-pointed, straight-veined leaves; fruit 3 -seeded, and flowers without petals; stamens 5.

Rhamnus catharticus, Linnaus. Common EURopeAn BuckTHorn. Petals present; stamens 4; ovate leaves finely serrate; fruit 3- to 4-seeded. Introduced from Europe, and used for hedges on account of its thorny branchlets. Is a violent cathartic, and as such is used in veterinary surgery.

Rhamnus infectorius, Linnaus. Staining Buckthorn, Avignon BERRY. A spiny shrub from Southern Europe, with 4 petals, 4 stamens, and usually a 4-seeded berry; leaves ovate-lanceolate, finely toothed, male and female flowers on different plants. This species is one of the sources of the Yellow or Persian Berries "used by dyers in calico-printing." From the bark of two other species the Chinese prepare a beautiful green dye for their silks. It is now imported under the name of Chinese Green Indigo.

\section{ROSACEA, Rose Family.}

Herbs, shrubs, or trees with alternate leaves and regular flowers; petals separate; stamens mostly many, free from one another, and inserted on the calyx. Pistils one to many, usually separate; seeds one to several. This important order is mostly destitute of noxious qualities, the common exception being in the "leaves, bark, and kernels of some cherries and the like," which contain prussic acid. The family is divided into a number of well-marked natural groups.

Amelanchier. June-Berry, Service-Berry. Calyx-tube adhering to the ovary and becoming a small succulent fruit, enclosing the 5 ovaries, each of which is divided by a partition, so that the fruit shows ro cells ; styles 5 . Trees or shrubs with the petals long and narrow and clustered along the then leafless branches.

Amelanchier Canadensis, Torrey and Gray. Shad-Bush, ServiceBERRY. A conspicuous species of several forms, hut ranging in size from a small shrub to a tree 30 feet high, distinguished by its attractive white flowers (on the leafless branches), which appear in early spring. A common native, of wide range. It has produced a number of forms under cultivation.

Cotoneaster. Ovary included in and when mature adherent to tube of the calyx; cells of the ovary and styles each 2 to 5 , each cell 2-ovuled; mature fruit of 2 to 5 hard nutlets; stamens many, inserted in the mouth of the calyx. Trees or shrubs, erect or decumbent. 
Cotoneaster baccilaris, Millich. "Ilasobovate leaves and many-flowered cymes. It is a native of Kumaon." Has produced some varieties.

Cotoneaster buxifolia, Wallich. Box-Lfaved Cotoneastr.r. A whiteflowered evergreen with ovate leaves, which are woolly on the under surface. From Neelgherry, in India. Hardy in England, where its beauty is much praised.

Cotoneaster frigida, Wallich. (Pyrus Nussia, Don.) A harrly, tall shrub with white flowers and bright-red fruit; leaves elliptical, thick woolly on the under surface when young; branchlets woolly. From colder parts of India.

Cotoneaster laxiflora, Fnizuin. Ieaves ohlong, blunt at either end, smooth above and woully on the under surface. Flowers pink.

* Cotoneaster vulgaris, Lindley. Common Cotonfastrr. Native of Silheria and the colder parts of Europe. Hardy. Flowers white or fleshcolored; fruit reddish, roundish; deciduous leaves an inch long.

* Cotoneaster microphylla, Wallich. Small-Leaved Cotoneaster. Flowers white; herries scarlet; small, leathery leaves an intense green. A very handsome shrub.

Cratzgus. HAwTHORN. Stone-fruited trees or shrubs with thorny branches and flowers in flat-topped clusters terminating the branchlets; leaves deeply toothed or lobed and toothed; cells of the ovary as many as the styles, which are 1, 2, or 5. Fruit of some species eaten by boys and birds.

Cratagus xstivalis, Torrey and Gray. Summer Haw. Small tree from the Southern States; with ovate leaves, which are thick, wedge-shaped towards the base, and somewhat bluntly toothed above the middle; flowers 1 to 6 in a cluster; acid fruit large, red, and juicy, "used for tarts."

Cratagus apiifolius, Michaux. Parsley-LeAved Thorn. A small tree, native from Viryinia south; smooth downy when young; leaves with a broad or heart-shaped base, deeply 5- to 7-cleft, lobes sharply cut-toothed; ovoid fruit deep red; " flowers rather large."

Cratægus coccinea, Linnaus. Scarlet-Frutted Thorn. Flowers large, $3 / 4$ inch across, many in a cluster; ovoid fruit $1 / 2$ inch across, bright red or scarlet; leaves ovate, slightly lobed, but with many sharp teeth. Has several varieties.

Cratagus cordata, Aiton. Washington THorn. Small tree from the States south of us; with many small 5 -styled flowers in a flat-topped cluster; fruit bright red, $1 / 4$ inch or less in size; leaves triangular or heart-shaped, variously 3 - to 5-cleft-toothed. Used as a hedge-plant.

Cratxgus Crus-galli, Linnaus. Cockspur THorN. Native shrub or small tree, very thorny, valuable as a hedge-plant; leaves thick, firm, lanceolate or obovate, deep green, and toothed above the middle; flowers large; fruit edible, bright red.

Cratzegus flava, Aiton. Yel.Low HAw. Small tree from Virginia south. ward; flowers rather large, few in a cluster; fruit slightly pear-shaped, yellow- 
ish, greenish, or reddish; leaves smooth or a little downy, ovate, with tapering base deeply toothed aloove the middle. This species has a well-marked variety, pubescens, Gray, which is known in gardens as C. elliptica, Aiton.

Cratægus glandulosa of the gardens appears to be simply the variety prunifolia, Torrey and Gray, of C. Crus.galli.

Cratægus orientalis, Bosc. EASTERn THORN. Low tree from the East, readily known by its hoary-white branches, its 3 -lobed leaves, which are downy on the under surface, and its large, yellowish-red, edible fruit.

Cratægus oxyacantha, Linneus. English HAwTHORN. Introduced for use and ornament from Europe; flowers not large, many in a cluster; fruit coral-red; leaves broadly wedge-shaped at base, deeply lobed and toothed above. It has produced many varieties in color of the flowers, etc., and to it some nominal species are reduced.

Cratægus parvifolia, Aiton. DWARF THORN. Native of "pine barrens from New Jersey south. Shrub 3 to 6 feet high, downy, with thick, firm, spatulate, obovate crenate leaves. These, as well as the mostly solitary flowers, almost sessile; the large fruit pear-shaped or globular, greenish and yellowish."

Cratægus prunifolius, Bosc, of the gardens is now regarded as simply a form of $C$. Crus-galli, which see.

Cratægus Pyracantha, Persoon. Evergreen Thorn. Introduced from Europe, but now grows wild near Philadelphia. The evergreen leaves are an inch long, broadly lance-shaped, and with small blunt teeth; flowers many; fruit bright red, very small.

Cratægus pyrifolia, Aiton, of the gardens is a form of C. tomentosa, Linnaus, which see.

Cratægus tanacetifolius, Persoon. Tansy-Leaved Thorn. From the Orient; has hairy, sharply-cleft leaves with lubes few-toothed; fruit globose, yellowish green.

Cratægus tomentosa, Linnaus. BLACK THORN. Tall, common native shrub, with many large flowers and large orange or scarlet fruit in a cluster; soft hairy when young; thickish oval leaves sharply and deeply toothed, tapering below into a margined foot-stalk. Very variable, and fruit of some forms quite pleasant-tasted.

Exochorda. A bush from China, with regular flowers, and 5 pistils united by their inner faces to the central axis, each having 2 suspended ovules on a conspicuous cord, which remains after the carpels have fallen.

Exochorda grandiflora, - ? (Spirca grandiflora.) Leaves lanceshaped and entire; white flowers conspicuous, in clusters on the ends of the branches.

Kerria. Japan Corchorus. Chinese and Japanese shrub, with lightgreen branches terminated by yellow flowers; fruit dry, seed-like.

Kerria Japonica, De Candolle. Leaves ovate-lanceolate, irregularly toothed. In the natural condition it has 5 petals and numerous stamens; now much changed by cultivation. 
Potentilla. Cinquefolr. Five-Finger. Usually herbs, with the I-seeded fruits heaped into a little head; calyx with 5 small leaves alternating with its lobes and outside of them. We have in the Park a single shrubby species:

Potentilla fruticosa, Limnous. Shrubry Cinģeforl. Is from $x$ to 4 feet high, branched and silky; compound leaves made up of 5 to 7 entire, broadly lanccolate leaflets. Native.

Prunus. Prum, Cherry, Peach, Almond, etc. Trees or shrubs with a single pistil, which develops into a stone fruit; flowers white or rose color, or white with a rose blush. The edible fruits are well known. In Eastern countries the fruit and bark of some are used as remedies. The genus was formerly divided into a number of others, such as Amygdalus, the Almond, Peach, and Nectarine group; Cerasus, the Cherry group.

* Prunus Alleghaniensis, Porler. A branching straggling shrub, seldom thorny; leaves lanceolate to obovate; flowers 2 to 4 in a cluster; fruit dark purple, globose ovoid, under $1 / 2$ inch in length, stone "with a shallow groove on one side and a broad flat ridge on the other." From the mountains of Pennsylvania.

* Prunus Americana, Marshall. Wild Yellow or Red Plum. (Cerasus Canadensis, Loiseleur.) Ovate leaves conspicuously pointed, sharply double-toothed; flowers white, not many in a cluster, appearing about the time the leaves do; orange or red fruit over $1 / 2$ inch in diameter, or larger in cultivation; stone sharp on each margin; pulp of fruit pleasant, but skin astringent, bitter, and sour. A thorny native, 8 to 20 feet high.

Prunus Caroliniana, Aiton. Mock-Orange. A small tree from the Southern States, with the white flowers in clusters from the axils of the thick, evergreen, broadly lance-shaped, entire leaves. Hardiness doubtful.

Prunus Cerasus is the common garden Red Cherry. Now growing in portions of the Park.

* Prunus Chicasa, Michaux. Chickasaw Plum. Native shrub 6 to 12 feet high. Somewhat thorny; leaves long and narrow, sharp-pointed, finely toothed; fruit round, well tasted, and over $1 / 2$ inch in diameter.

Prunus Lauro-Cerasus, Linneus. Cherry LAuret. (Cerasus LauroCerasus, Loiseleur.) Jeaves thick and leathery, bruadly lance-shaped, sparingly toothed, resembling those of the common Orange. Not hardy. Puisonous, from the abundance of prussic acid.

* Prunus maritima, Wangenheim. Beach Plum. Low shruh, native alung our sea-shores; flowers white, appearing in early spring; leaves oval, sharp-pointed, decidedly veiny, deeply and doubly serrate; fruit $1 / 2$ to $\mathbf{I}$ inch in diameter, stone sharp on one edge and a little grooved on the other.

Prunus nana, - - ? DWarf or Fr.owering Almond. Has short clusters of mostly double flowers appearing before the leaves in spring, naturally rose-colored, but by variation white. A low, much-branching shrub, introduced into cultivation from the Calmuck region in Asia.

Prunus Pennsylvanica, Linneus. WiLd ReD Cherry. (Cerasus I'ennmbania, Sermire) A small migenus tree with shining green, smeoth, 
finely-toothed leaves, which appear about the same time as the clusters of longstalked flowers; round fruit sour and small. Prunus borealis, Poiret, of the gardens and the older works, belongs to this species.

Prunus pumila, Linnaus. Dwarf Cherry. (Cerasus pumila, Michaux.) A trailing native shrub, not over 18 inches high; obovate leaves tapering towards the base and toothed towards the apex; flowers 2 to 4 in a cluster.

Prunus serotina, Ehrhart. Wild Black Cherry. (Cerasus Virginica, Michaux.) Large native tree, with handsome, valuable wood, and broadly lance-shaped, taper-pointed, thick leaves, which have small incurved teeth and a shining upper surface; fruit a little bitter, but not decidedly unpleasant.

Prunus Virginiana, Linnaus. СhoKe Cherry. (Cerasus Virginiana, Loiseleur.) Large shrub, with leaves (coming before the flowers) oval, abruptly pointed, sharply single- or double-toothed; flower-clusters short and dense; fruit becoming dark crimson, when it is barely edible. Prunus rubra, Aiton, is the same species.

Pyrus. Pear, Apple, etc. ${ }^{x}$ Shrubs or trees in which the calyx grows fast to the ovary and becoming engorged forms the edible fruit. Often thorny; flowers in flat-topped clusters, or occasionally single; style 2 to 5 ; fruit weil known and of great service to man; best developed in cold rather than in warm climates; wood compact, used somewhat in the arts. It has heen proposed as a substitute for boxwood in coarse engraving, though probably better material will be found.

Pyrus Americana, Chamisso and Schlechtendahl. American Mountain Ash, Rowan-Tree. (Sorbus Americana, Marshall.) Small, slender tree, native in the cooler parts of this State and northward; bark smooth; leaves made up of about $\mathbf{1} 5$ bright-green, sharp-pointed, sharp-toothed leaflets; clusters of bright-scarlet fruit, ornamental in autumn, adhering even after the fall of the leaves, each berry $1 / 4$ inch in diameter. Much like the following, which comes from Europe:

Pyrus Aucuparia, Gärtner. European Rowan. (Sorbus Aucuparia, Linnaus.) Larger tree, with blunter leaflets and larger berries $(1 / 2$ inch in diameter), than the above. Introduced for ornamental planting.

Pyrus arbutifolia, Linnaus. CHokeberRy. A common native low straggling shrub, found in wet woods; leaves simple, oval or obovate, thickish, bright green, and finely toothed; flowers white in flat-topped clusters on the ends of the branches; purple or black berry nearly round, $1 / 4$ inch in diameter. Pyrus floribunda, Lindley, of the gardens appears to belong here.

Pyrus baccata, Linncus. (Malus baccatq, Desfontaines.) From Dahuria. The leaves ovate, acute, smooth, equally toothed, and ahout as long as the leaf-stalk; fruit apple-like in shape. Has produced some varieties in cultivation.

Pyrus coronaria, Linneus. American or Garland Crab-Apple. (Malus coronaria, Miller.) Native species; small tree with the ovate leaves roundish or heart-shaped at base and somewhat 3 -lobed ; flowers rose-colored or whitish tinged with rose-color, fragrant, as is also the greenish-colored astringent fruit.

1 Pirus is now the accepted orthography of the above-named. We have, however, adhered to the old, simply in order to avoid confusion in a mere list like this. 
Pyrus intermedia, Ehrhart. Intermediate Whate. BeAm-TreE. From Eurupe, especially the colder parts; with ovate lolved or deeply-toothed leaves which are white hairy beneath; flowers in branching flat-topped clusters; edible fruit globose.

Pyrus Japonica, Thunberg. JaPAN Quince. (Cydonia Faponica, Persoan.) Low shrub, from Japan; thorny, smooth, with large scarlet, rose-colored, or white flowers, which appear earlier than the oval or oblong, bluntly-toothed leaves; young fruit with 2 ovules in each cell; mature fruit green, hard, knotty, and worthless. A common showy plant, making beautiful hedges.

Pyrus salicifolia, Linnaus. Whllow-Leavfd Pear-Tree. About 20 feet higin. Native of Siberia, Caucnsia, and Persia. Leaves narrowly lanceshaped, sharp-pointed, and white hairy on the under surface, blade thrice as long as the leaf-stalk; flowers few in a cluster; buds covered with a white wool.

Pyrus sambucifolia, Chamisso and Schlechterdahl. Small tree, native along our northern borders, and closely related to the American Muuntain Ash (see above), but with oblong, ohtuse, blunt- or sharp-pointed leaves. Once regarded as a form of $P$. Aucuparia, and still known in some gardens as $P$. hybrida, Aōnils.

Besides the species enumerated above, the following well-known trees belong here: Pyrus communis, the Common PEAR; Pyrus Cydonia, the Common Quince; Pyrus malus, the Apple-TreE.

Rosa. Rose. - Shrubs, usually prickly, with compound leaves of generally 3 to 12 toothed leaflets; stipules (small leaf-like organs) united to the base of the common leaf-stalk; flowers large and conspicuous, either solitary or in clusters, terminating the branches; seed enclosed in an urn-shaped fleshy cup, which is contracted at the top and crowned by the calyx-lobes. A well-defined natural group, with over 200 recognized species, of which nearly or quite a hundred are now in cultivation, and out of these an innumerable host of varieties has been produced. Besicles the sense of the beatuiful which is gratified by this "Queen of Flowers," the rose is also an important source of empluyment to thousands who manufacture rose-water and attar. The wood is valuable for certain fine purposes, and it has also been proposed as a substitute for boxwood for the engraver's use,-probably a poor substitute. We cannot attempt even a list of the varieties in a brief synopsis like this. Hence we will simply enumerate the common native and foreign forms the Park has or ought to have.

* Rosa blanda, Ailon. EARIY WILd Rose. Styles separate, with the stigmas closing the mouth of the calyx-tube; not a climber; prickles, if any, weak; leaflets 5 to 9 , oblong and blunt-pointed, whitish or hairy on the under surface; flower-stalk and calyx smooth; mature fruit nearly globular. Native.

Rosa canina, Limnaus. Dog Rose, European plant, now sparingly naturalized here, much resembling our native sweethrier; stipules large, lanceolate, neally entire; leaflets about 7, oval, smooth, sharp-pointed and sharply serrate; pink or whitish flowers in clusters of 3 to 5 ; prickles stout.

Rosa Caroliniana, Linnous. Swamp Rose. A not rare native, often troublesome in low grounds; the divinct styles closing the mouth of the calyx with their stigmas; Jeaflets 5 to 7 , lanceolate to olslong, finely toothed except at base; calyx and fruit glandular hairy; flowers often many in a cluster; prickles rather stout, recurved. 
Rosa cinnamomea, Linneus. Cinnamon Rose. From Europe; with slender, scattered prickles, oval and coarsely-toothed leaves which are hoary and glandular beneath; flowers pale red, small, and somewhat cinnamonscented, whence the popular name.

Rosa lucida, Ehrhart. Dwarf Wild Rose. Separate styles included in the calyx and closing the mouth with their stigmas; low bushy native, with weak nearly straight prickles and lance-shaped or broader leaflets which are plainly toothed; caly $\mathrm{x}$ more bristly than the somewhat depressed fruit. Not a climber.

Rosa multiflora, Thunberg. Many-Flowered Rose. From China and Japan. Common and hardy here; climber; leaflets soft and somewhat roughened; prickles scattered, slender; inodorous flowers in clusters, white, pale red, or red; styles united and projecting.

Rosa rubiginosa, Linneus. Sweetbrier. From Europe, but naturalized here by the wayside and in old garden: Climber; prickles strong and hooked; leaflets with brown glands on the under surface, small, double-toothed, and downy; pink flowers usually single; fruit pear-shaped.

Rosa sempervirens, Linnaus. Evergreen Rose. From Europe, but neither hardy nor evergreen here; leaflets thick, bright green, oblong; prickles curved; flowers white; styles united and projecting from the calyx. The Ayrshire Rose of the British gardens is given by Gray as a variety of this, and by Loudon as a variety of the European Field Rose (R. arvensis, Hudson). It is more hardy than the $R$. sempervirens.

Rosa setigera, Michaux. Climbing Rose, Prairie Rose. A prickly, climbing native, with the united styles protruding from the calyx and as long as the stamens; with 3 to 5 ovate, sharp-pointed, sharp-toothed leaflets. A vigorous grower, with flowers from white to deep rose-color.

* Rosa sulphurea, Aiton. Yellow Rose. From the Orient; young shoots without prickles; 5 to 7 obovate, slightly-toothed, smooth, pale leaflets; flowers double and (as the name implies) sulphur yellow.

Beyond this we cannot go in this enumeration.

Rubus. Bramble, Raspberry, Blackberry, etc. Shrubs or hard herbs; calyx neither becoming a fleshy tube or cup nor closing over the fruit; the pulpy I-seeded ovaries crowded on a central convex receptacle. A genus furnishing many fruits, and some ornamental plants, and also a mild astringent for medical use. It is widely distributed, and has many species.

Rubus cordifolius, Weihe and Nees. Heart-Leaved Bramble. An unattractive German species, with the stem decurved-angled and grooved; thorny; leaves of 3 to 5 round heart-shaped leaflets, which are white hairy beneath; flowers small, white; fruit black with a whitish coating.

Rubus fruticosus, Linnaus. Shrubby Bramble. From Europe. Erect stem 5-angled and woolly; leaves of 3 to 5 ovate oblong acute leaflets, which are white woolly on the under surface; flowers white or rose-colored; fruit dark purple.

Rubus laciniata, Willdenow. Foreign shrub of unknown nativity; with round stem and strongly recurved prickles; 3 to 5 leaflets deeply cut and 
toothed; white or rose-colored flowers in a loose cluster; weclge-shaped petals 3 -lobed at the apex.

* Rubus Nutkanus, Mocino. White-Flowfring Raspinerry. Native, from Michignn westward; no prickles, not bristly; leaves simple, 5-lobed, coarsely toothed; flowers large, white, and few in a cluster.

Rubus odoratus, Linnaus. Shrub with the "branches, stalks, and calyx bristly with glandular clammy hairs;" leaves 3- to 5-lobed and finely toothed; large flowers "purple rose-color." Common in our colder woods.

Rubus rhamnifolius, Weile and Niees. Shruh from Germany, with stem angled, grooved, and prickly, and not erect; leaflets 3 to 5 , round, pointed, and hairy on the under surface. An unimportant species, with dark fruit.

Rubus strigosus, Michaux. WILD RED RAsPBIRry. Native; erect; younger parts covered with bristles or weak prickles, older parts prickly; Jeaflets 3 to 5 , oblong, pointed, cut-tnothed, and white on the under surface; terminal one sometimes stalked, lateral ones never; flowers small, white; fruit light red, well flavored, and falling from the receptacle when ripe.

Rubus tiliæfolius, Weihe. Linden-Ifaved Bramble. Native of Germany; stem round and smonth; leaves with 5 ovate, heart-shaped, sharppointed, slightly-toothed leaflets; prickles nearly straight.

Rubus triflorus, Richardson. Dwarf Raspbrerry. Native; annual, herlaceous, without prickles; white flowers small, and fruit of but few grains; 3 to 5 leaflets thin, smooth, and sharp at both ends; flowers $\mathbf{I}$ to 3 in a cluster. R. mucronatus, Seringe, of the gardens belongs here.

Spiræa. Shrubby or sometimes herbaceous; calyx short, usually 5-cleft, neither thickening into a fleshy cup nor closing over the fruit; ovaries from 2 to 12 , with several seeds and opening along the one side; stamens usually numerous.

Spiræa alba, $D u R o i$, of the gardens is $\mathbf{S}$. salicifolia,-which see.

Spiræa ariæfolia, Smith, of the gardens is S. discolor,-which see.

Spiræa betulifolia, Pallas. Birch-Leavfid SpiraA. (Spiraa corymbosa, Gray's Manual; spiraa chumadrifolia, var, media, Pursh.) Shrub from northern regions, with white flowers in close, compound, flat-topped clusters; leaves oval, smouth, and more or less toothed; ovaries 5 , smooth.

Spirza callosa, Thunberg. (Spirca Fortuni.) Native of Japan. Shrub with deep pink flowers in flat-topped clusters which terminate the branches; "10 glands at the mouth of the calyx ;" narrowly oblung taper-pointed leaves sharply and unequally toothed.

Spirza discolor, Pursh, var, ariæfolia, Watson. (Spirra ariafolia, Smilh.) Tall, slender, branching shrub, from Oregon, with a large, drooping, compound mass of small yellowish-white flowers; the roundish, blunt-pointed, thin leaves with several blunt and towthed lobes (or often deeply cleft), more or less soft downy.

Spiræa Douglasii, Hooker. Doucilas' Mradow-Sweet. Shrub from California and Oregon, with pink flowers in close, narrow clusters terninating 
the branches; blunt leaves broadly lance-shaped, and under surface whiter than the upper.

Spiræa Fontenaysi, — ? is "a fine-growing species with quite large panicles of pure white flowers."

Spiræa lanceolata, Poirel. (Spirca Reevesiana). Shrub from China. Flowers white, handsome, in simple clusters; leaves oblong or sometimes 3-cleft, serrate-toothed.

Spiræa lævigata, Linnaus. From Siberia. Shrub with oblong, smooth, entire leaves ; flowers white, disposed in cylindrical clusters along the branchlets; astringent leaves used in Siberia for tea, and the slender stems utilized by the Cossacks for ramrods.

Spiræa opulifolia, Linnceus. NINE-BARK. This species is now known as Neillia opulifolia, Bentham and Hooker. Native shrub, with the bark separating in thin layers; branches thin and recurved, heart-shaped leaves 3 -lobed and cut-toothed; flowers white in flat-topped clusters; purplish pods inflated.

Spiræa prunifolia, - - ? Pi.um-Leaved Spirea. Slender shrub from Japan; flowers in simple clusters on the branches of the previous year, earlier than the true leaves, which are ovate, smoothish above, and with fine, sharp teeth. The form cultivated has full double pure white blossoms $1 / 2$ inch in diameter.

Spiræa salicifolia, Linnaus. Common Meadow-Sweet. A smooth native shrub, with narrowly oblong somewhat toothed leaves, which are often wedge-shaped at base, and white or nearly white flowers crowded in a compound cluster. Spiræa alba, Du Roi, of the gardens belongs here.

Spiræa sorbifolia, Linnaus. Shrub from Siberia, with compound leaves of 17 to 21 lanceolate, taper-pointed, sharply-toothed leaflets; fluwers white, in a spreagding cluster terminating the branchlets.

Spiræa tomentosa, Linnaus. Hardhack or Steeple-Bush. Native bush, with simple, oblong-toothed leaves, which are white or brown hairy on the under surface; flowers purple, sometimes white in a crowded cylindrical mass at the ends of the branches; young shoots also covered with white or tawny hair.

Spiræa trilobata, Linnaus. Spreading shrub from Siberia; leaves bluntly toothed and 3-lobed; flowers white and rather showy.

Spiræa ulmifolia, Scopoli. Elm-Leaven Spiræa. A compact shrub from Siberia; broadly lance-shaped, deeply serrate, bristly-nargined leaves; white down-like flowers in a dense hemispherical terminal cluster.

Spiræa vaccinæfolia, Don. A small erect shrub from Nepaul, with acute smooth elliptical leaves, which are toothed at the apex and glaucous on the under surface, the terminal flat-topped clusters few-flowered and downy.

\section{RUBIACE $\mathbb{E}$. Madder Family.}

Usually shrubs. Calyx and 2- to 5-celled ovary united, stamens equal in number to the lobes of the corolla and on its tube; leaves opposite, entire, 
with stipules or whorled and without stipules. The madder used in dyeing comes from the root of Rubia tinctorum. Other species are said to yield a dye.

The single species with which we are concerned is

Cephalanthus occidentalis, Iinnacus. Burrox. Bisu Shrub with the Ary fruit aggregated into a dense globular mass an inch in diameter and on a long slender stalk; slender style much protruded from the 4-lubed corolla. A common native, with lance-shaped or oblong leaves, 3 in a whorl.

\section{RUTACE $A$. Rue Family.}

Leaves either simple or compound, with transparent puncture-like dots containing an aromatic oil; stamens as many or twice as many as the sepals, inserted on the receptacle or disk surrounding or elevating the ovary. Petals not united; leaves opposite or alternate, without stipules. The Orange is now placed in this order, which also contains many plants with medicinal properties.

Phellodendron. Ovary maturing into a berry-like stone fruit with 5 seeds; flowers with pistils and stamens on different trees.

"Phellodendron Amurense, Ruprecht. Tree native of Eastern Siberia; leaves opposite, unequally pinnate; leaflets 2 to 6 pairs, oblong-lanceolate and long-acuminate, 3 or 4 inches long, serrulate, very slightly villous on the midvein beneath, not punctate. Flowers green in axillary and terminal pedunculate corymbs. Parts of the male flower in 5, the female flower unknown." Sereno Witson.

Zanthoxylum. Flowers with pistils and stamens on different plants; sepals (when present), petals, and stamens in the male flowers 4 or 5 ; pistils 2 to 5, distinct, though the styles are slightly united. Shrubs or small trees with compound leaves, stems prickly.

Zanthoxylum Americanum, Miller. Northern Prickly Ash, ToothACHE-TREE. A prickly native shrub, with the yellowish-green flowers appearing before the leaves, which have 9 to 11 ovate leaflets; calyx wanting; flowers in clusters in the axils of the leaves. "Bark, leaves, and pods very pungent and aromatic."

* Zanthoxylum Carolinianum, Lambert. Southrre Pricki.y Ash. A small prickly tree growing along the coast from Virginia southward; leaflets 7 to 11 , ovate-lanceolate, oblique; flowers in a flat-lopped terminal cluster coming after the leaves; calyx present.

Skimmia. An evergreen shruh from Japan, with perfect flowers and simple leaves. The species here introduced is

Skimmia Japonica, Thumberg; which has inconspicuous. white, fragrant flowers, and bright-red berries which remain through the winter. 


\section{SALICACEAE. Willows and Poplars.}

Trees or shrubs with the male and female flowers separated; with only a single flower under each scale, but collected into scaly, often hairy, elongated compact clusters; neither calyx nor corolla present; leaves simple alternate. Wood light, and for'general purposes unimportant; bark containing a bitter principle which was once much and still is a little used in fever and ague. The young twigs and leaves form in times of great scarcity a fodder for stock, and from the willows basket-ware is largely made.

Populus. Poplar. Scales of the flower-clusters cut or fringed at the apex; stamens several, or more; stigmas long, and leaves usually broad, from lance-shaped to broadly heart-shaped.

Populus alba, Linnaus. Abele, White Poplar. A middle-sized tree, introduced from Europe, but threatening to become a nuisance from its tendency to spread by the roots; buds not sticky; leaves heart-shaped, wavytoothed or lobed, white cottony hairy on under surface. Used in England for measures, tubs, and the like, and also cut into thin strips for veneering, having a fine satiny gloss when finished.

Populus angulata, Aiton. Angled Cottonwoon. Branches sharpangled; leaves triangular heart-shaped, bluntly toothed, and on young shoots very large. Native tree.

Populus balsamifera, Linneus. Balsam Poplar, TACAmahac. A middle-sized native tree; buds glutinous and aromatic; branchlets round or very slightly angled, and leaves lance-shaped or broader, but with tapering points. The familiar BALM OF GILEAD TREE is the variety * candicans, Gray, of this species. It has, however, broader leaves on hairy stalks.

Populus grandidentata, Michaux. LARge Toothen Aspen. A large native tree, with nearly round, deeply and irregularly toothed leaves, and the flower-scales only slightly fringed.

Populus monilifera, Aiton. Cottonwoon, Necklace-Poplar. (Populus Canadensis, Desfontaines, in Prodromus of De Candolle, and of which P. angustifolia, Fames, is considered a variety.) A large native tree, with round or slightly angled young branchlets, and broadly triangular large leaves, which are squarely cut or somewhat heart-shaped at base, and taper-pointed, with hard and somewhat incurved and slightly hairy teeth.

Populus nigra, Linnaus. Black Poplar. From Europe. A tall tree of very rapid growth, with very sticky buds and nearly triangular leaves, which are green on both surfaces, heart-shaped at base, taper-pointed, and bluntly toothed. The well-known LOMBARDY POPI.AR, so conspicuous for its tall spire and early death, though probably but a variety of this, is still known in grounds as Populus dilatata, Ailon. We have only the staminate tree here.

Populus tremuloides, Michaux. American Aspen. A middle-sized native tree, the buds of which are not sticky; the young leaves cottony, old ones smooth, "roundish heart-shaped and finely toothed." Populus Græca, Aiton, of the gardens, formerly regariled as a native of the Mediterranean region, is now considered a native of this country and as coming under this name. 
Salix. WuLow. Sterile flowers usually with 4 stamens; fertile flowers with 2 short stigmas and with a little gland on the inner side of the base of the ovary; scales of the usually elongated compact flower-clusters not cut or fringed. Of no great importance in the arts.

Salix alba, Linnous. Wиite Willow. A tree 50 to 80 feet high, naturalized from Europe; flower-clusters appearing after the lance-shaped, pointed, toothed leaves, which are somewhat white silky hairy beneath; stamens to each fower 2; stigmas short, thick, and recurved. The form in more common cultivation is variety vitellina, Andersson, which is $S$. vitellina, Linnaus, and of the gardens.

Salix Babylonica, Limners. WeEring Willow. A well-known, goodsized tree from Persia and the Caucasian region, and of which besides the type form we have the variety Japonica, Andersson, from Japan. It is the S. Faponica, Thumberg, and of the gardens. It is recognized by the broad, symmetrical lance-shaped leaves with many long teeth, and by irs numerous long and loose flower-clusters. There is also the variety annularis, Forbes, which is a monstrous form with narrowly lance-shaped leaves which are coiled into a ring, whence the name of HuOPED WiLlow, often given to it.

Salix caprea, Linnceus. Sallow Willow. European shrub or small tree, with nearly smooth, ovate, entire or toothed leaves and conspicuous stipules; male flowers in short or oblong heads, with a few scales at base; female heads longer and loosely flowered, ovaries hairy and on a short stalk; flowers appearing before the leaves. Variety pendula is the KILMARNOCK WILlow, characterized by its drooping branches which admit of training into a beautiful weeping tree.

* Salix cordata, Muhlenberg. Heart-Leaved Wit.low (a misleading name). Native shrub or small tree, loving wet grounds; lance-shaped or broadly lance-shaped leaves, taper-pointed, sharply toothed, pale, and coming immediately after the flowers; stamens 2 , under the dark, hairy, persistent. scales.

* Salix discolor, Muhlenberg. Glaucous Willow. A common native shrub or small tree with leaves lance-shaped to oblong, acute, "irregularly toothed at the sides;" scales and ovary very hairy; stipules conspicuous, toothed, lunate. Flowers appearing before the leaves.

Salix longifolia, Muhlenberg. Long-Leaved Willow. Shrub or small. native tree, which flowers after the linear lanceolate, tapering leaves have appeared; stamens 2; ovary stalked; stigmas very large, sessile.

* Salix lucida, Muhlenberg. Shinivg Willow. (Salix pentandra, Nultall, and of the gardens.) Long loose flower-clusters appearing after the broadly lanceolate, tapering, shining, toothed leaves; stamens 5, or sometimes more. Native, 15 feet high.

* Salix nigra, Marshall. Black Wit.low. Much like the above, save that it has narrower leaves, which are pointed at each end; stamens 3 to 6 ; 20 to 25 feet high. Native.

Salix petiolaris, Smilh, var. sericea, Anderssons. (Salix rosmarimifolius, Poursh, and in gardens; Salix sericea, Marshall.) Native shrub, to feet high, with flowers appearing befure the leaves, which are lance-shaped, downy on upper and grayish silky hairy on under surface; flower-scales blunt and roundish; stigmas sessile. 
Salix triandra, Limnaus. Thrfe-Stamenen Willow. (Salix Villarsiana, Fluggi, and in gardens.) European shrub or small tree with lanceshaped, round-based, shining leaves, and slender flower-clusters 2 to 3 inches long; stamens 3 .

\section{SAPINDACERE. Soapberry Family.}

Trees or shrubs; leaves compound or lobed; stamens usually not twice as many as the petals, but when just as many then inserted alternate with them; disk on which the petals are inserted lines the bottom of the calyx; ovary 2 - to 3 -celled, with $\mathbf{I}$ to 3 or several ovules in each cell. An order not specially characterized by active properties, though of some importance in the arts.

Acer. Maple. Trees with lobed leaves and a 2-seeded, 2-winged fruit. Sexes more or less separated functionally.

Acer campestre, Linnaus. Common English Maple. A midale-sized tree with leaves 2 to 3 inches across, and with about 5 broad, blunt lobes. Mature fruit downy, and wings diverging so as to enclose no angle,-i.e., straight out. Hardy here. There is a variegated form in the grounds.

Acer dasycarpum, Ehrhart. White or Silver Mapi.e. A fair-sized native tree; flowers without petals, coming before the deeply 5-lobed gashtoothed leaves, which are whitish on the under surface; young fruit hairy, wings large, diverging. There are pendulous and cut-leaved varieties of this species.

Acer macrophyllum, Pursh. Soft Maple, Broad-Leaved Maple. Large tree of our Pacific coast. Large heart-shaped leaves deeply 3 - to 5 -loberl, with the lobes again sharply cut; stamens 9 or 10 , with hairy filaments; body of fruit densely hairy. A most valual,le timber tree, and for some purposes the best substitute for hickory the Western coast furnishes.

Acer obtusatum, Kilaibel. OBtuse-Leaved Maple. From the dry mountains of Hungary and Croatia. Heart-shaped leaves with 5 obtuse lobes, velvety on the under surface; wings of the fruit not widely diverging.

* Acer Pennsylvanicum, Linneus. Monse-Wood, Striped Dogwood. A slender native tree with drooping greenish flowers appearing after the leaves, which (the leaves) are 3 lobed, sharply double-toothed; fruit with large spreading wings; bark green faintly or strongly striped with lighter lines. Known in grounds often as A. striatum, Lambert.

Acer platanoides, Linneus. Commonly called Norway Maple. European tree, introduced here; broad, thin, smooth leaves with 5 lobes which are conspicuously sharply-toothed, appearing before the flowers; stamens 5 or more; juice milky. Wings of fruit 2 inches long. This species has produced the varieties dissectum, with deeply-cut leaves, and laciniata, with the leaflobes resembling claws.

Acer polymorphum, Thunbers. A Japanese species of recent introduction. Said to be hardy here, and promising to become with us a fair-sized tree, it being in some of its varieties in its own country a dwarf. The Park has on trial 4 varieties: of these, dissectum, palmatum, and septemlobum were once regarded as distinct species. 
Acer Platanus, Linncus. Sycamore. Mapi.E. Large tree from Europe and Western Asia. Leaves large, lobed, tonthed, somewhat hairy on the under surface; foot-stalk reddish; stamens 5 to 8; wings of mature fruit diverging widely. Hardy and ornamental. Has produced varieties with purple, golden, and silvery foliage.

Acer rubrum, Linneus. ReD MAPI.E. A good-sized native tree, which procluces before the leaves appear a profusion of scarlet flowers (the fertile ones dronping); 3-to 5-lobed leaves with acute sinuses, turning bright scarlet in autumn.

Acer saccharinum, Wangenheim. Rock or SugAR-MAPLe. A noble native tree, with flowers appearing at the same time as the heart-shaped 3-to 5 -lolved leaves, which are slightly hairy on the veins beneath, notches in the leaves rounded; calyx-lohes hairy; petals none; wings of the large fruit only slightly diverging. A valuable wood in the arts, furnishing the BIRD'S-EYE and CIRLED MAPLE. The tree is hetter known still as the source of maple sugar and syrup. The variety nigrum, Gray; B1.ACK SUgAR MAPLE, was once regarded as a distinct species (Acer nigrum, Michaux), and is distinguished by having broader lubes and narrower notches to the greener leaves.

Acer spicatum, Lambert. Mouxtain Maple. Native shruh, with greeni-h flowers appearing before the 3 - to 5-lolsed, coar-ely-toothed leaves, which are downy on the under surface; stamens 5 to 8 ; flower-clusters erect, and fruit with small wings.

Acer Tataricum, Linncus. From Tartary. Leaves toothed, but not lobed; flowers in cluse erect compound clusters; wings of the fruit nearly parallel.

Asculus. Horse-Chestnut, Buckeye. Trees or shrubs with 5 to 9 leaflets from the summit of a leaf-stalk; young fruit 3 -celled, each cell with 2 young seeds; in mature fruit a leathery rind encloses one or more large chestnut-like seeds; conspicuous flowers of 4 to 5 long-clawed petals; stamen; usually 7 , often unequal.

Esculus flava, Aiton. Sweet Buckeye. Native tree, with the husk of the fruit not prickly; flowers yellow; petals 4 , of which the 2 upper are on longer claws, but with smaller blades; stamens not protruding from the flowers; leaflets 5 to 7 , smooth or nearly so. Known in some garden lists as Pavia fiara. var. purpurascens, Gray. PURPLe-Flowrend Buckeye. Fluwer of a dingy purple. It is the Esculus discolor, Pursh.

Esculus glabra, Willdenozo. Fftid Buckeye, Оhio Buckeye (erroneously named in some lists Pavia rubicunda or Pavia Ohioensis.) A favorite native iree; flower of 4 rather small, upright, pale-yellow petals, shorter than the slightly-curved stamens; fruit prickly when young; leaflets 5.

Asculus Hippocastanum, Linnaus. Common Horse-Chestnut. A well-known tree, the fruit of which is prickly when young; conspicuous in spring for its large dense pyramidal clusters of yellow- and rectdish-spotted white flowers; petals 5 ; stamens turned to one side; leaflets 7 . Originally frum Asia. Cultivation has produced varieties.

Asculus parvifiora, Waller. Small-Flowered or Dwarf Horsf. ChestNit. Hardy shrub from the Sulthern States, with white flowers in 
long clusters and 6 or 7 stamens which are thrice longer than the petals; fruit smooth. In the Prodromus of De Candolle, under Pavia macrostachya, a synonyme, Pavia edulis, Poiret, is found, which is uncited in some other works,

Asculus Pavia, Linnaus. RED BuCKEYE. A smooth-fruited native shrub or small tree, with stamens no longer than the bright-red flower. It appears in some catalogues as Pavia nubra.

Kœlreuteria. A small tree from China, but hardy here; well known by its toothed, pinnate leaves; 5 sepals ; 3 or 4 petals, each with a small notched scale on the inner surface of the claw ; stamens 5 to 8 , turned to one side; a 3-lobed, 3-celled inflated pod; flowers small, yellow, in large compound clusters. Our only species is

\section{Kœlreuteria paniculata, Laxm.}

Negundo. Ash-Leaved Maple, Box Elder. Like the maple, save that the pistils and stamens are on different trees, and the leaves are of 3 or 5 leaflets. Our Eastern species is Negundo aceroides, Mönch; a small tree with light-green branchlets and hanging clusters of small greenish flowers which come with or before the leaves. The tree is a nuisance on well-kept grounds, from the leaves falling the summer through, but, owing to the ease with which it is cultivated, it is an important tree on our Western naked plains, as a persistent thriver in bad soils and a hardy substitute for something better.

Staphylea. Shrubs with compound leaves. The perfect white flowers with 5 erect petals, sepals, and stamens, the last inserted on the disk lining the bottom of the calyx; styles 3 ; ovary 3 -lobed and 3 -celled, becoming a large, more or less inflated, several-seeded pod.

Staphylea Bumalda, De Candolle. A Japanese shrub, with 3 oblongpointed, roughish, toothed leaflets, which have bristle-points in the notches of the leaflets; style hairy; mature fruit 2-horned.

Staphylea pinnata, Linnaus. European Bladder-Nut. Shrub distinguished from the other species enumerated here by its 5 leaflets.

Staphylea trifolia, Linnaus. American Bladder-Nut. Native shrub, with 3 ovate, pointed, toothed leaflets and hanging clusters of white flowers; pods large and inflated; bark greenish and striped.

\section{SAXIFRAGACEÆ. Saxifrage Family.}

A large natural order, but hard to define. For our purpose the characters are: "Ovaries partly or wholly united, and seldom any stipules; the herbs and most of the shrubs of the family have only as many or twice as many stamens and fewer styles or stigmas than there are petals or sepals. Flowers mostly perfect."-Gray, School and Field Book of Botany, p. I3I. The group contains many handsome flowers, but, so far as utility goes, yields few remedial agents or woods of use in the arts.

Deutzia. Shrubs from China and Japan, conspicuously distinguished by their abundance of pure-white perfect flowers; 5 lobes to the calyx and 5 
petals, the edges of which furn slightly inwards in the bud; stamens 8 or so, the alternate unes longer and in some species with a tooth on either side near the top of the flat filaments.

Deutzia crenata, Sichold and Zuccarini. Well known in gardens; younger parts and leaves rough with short hairs; leaves pale, oblong or ovate, minutely and bluntly toothed; filaments widening upwards and toothed near the summit; usually called $D$. scabra. It has produced varieties under cultivation.

Deutzia Fortunii, — ? " is a new introduction, with dark-green foliage and a large white bloom."

Deutzia gracilis, Siebold and Zuccarini. Is only 2 feet high; with lanceshaped, dark-green, sharply-toothed leaves, and small white flowers with toothed filaments.

Deutzia scabra, Thunberg. Has roughish, finely and sharply toothed leaves; flowers white, drooping, and filaments tapering upwards without teeth.

Hydrangea. Shrubs with flowers in flat-topped clusters, of 2 kinds; the marginal ones with neither pistils nor stamens, and calyx enlarged and colored to resemble a corolla; central ones inconspicuous, but with 8 to ro stamens and 2 to 5 diverging styles; fruit opening on the top between the styles.

Hydrangea arborescens, Linnous. Small native shrub, with ovate, heart-shåped, somewhat pointed, toothed green leaves; flowers in a flat-topped cluster, of which the outer row may or may not be conspicuously enlarged.

Hydrangea Hortensis, De Candille. From China and Japan. Common in cultivation. The variety Otaksa, recently introduced from Japan, is said by Hoopes "to have corymbs of flowers of very large size, deep rose-color; foliage larger than the species. Growth vigorous and attractive."

Hydrangea deutziafolia, —? Also known as $\mathbf{H}$. paniculata. "The finest shrub of recent introduction, and especially beautiful. Flowers in very large panicles, pure white; and the plant is entirely hardy."

Hydrangea quercifolia, Bartram. OAK-Leaved Hydrangea. Native of the Southern States, but hardy with us; distinguished by its large oak-like leaves and its conspicuous and numerous marginal flowers.

Hydrangea radiata, Walter. (Hydrangea nivea, Michanx.) With ovate, heart-shaped leaves, pointed, and white wonlly on the under surface, hut green above; enlarged marginal flowers not numerous. Native from Virginia south.

Itea. Native shrub, with alternate, pinnately veined, oblong leaves; 5 -cleft calyx (almost free from the 2-celled ovary), in the bottom of which the 5 stamens and 5 lanceolate petals are inserted. Our species is

Itea Virginica, Linnaus. With handsome, simple, elongated clusters of small white flowers on the ends of the short lateral branches.

Philadelphus. Mock-Orantie, Syringa, Calyx and 3-to 5-celled ovary united, thuugh the lubes of the former are not prolonged beyond the top of the 
latter; leaves opposite; white or whitish flowers conspicuous, in clusters; stamens numerous. Flowers have a cucumber-like odor.

Philadelphus coronarius, Linnaus, Common Mock-OrAncie. Much cultıvated; supposed to be a native of Japan. Shrub with ovate or oblong leaves; flowers cream-color or white, in dense clusters. The $P$. Zeheri of the gardens is now regarded as a form of the above.

Philadelphus Gordonianus, Lindley. Shrub from California; 6 to 12 feet high ; branches spreading or recurved ; ovate or oblong leaves with coarse, sharp teeth; flowers white, $2 \frac{1}{2}$ inches across, in loose clusters.

Philadelphus grandiflorus, Willdenow. LARGE-FLOWERED MOCK-ORANGE. A tall native shrub from Virginia and southward, with ovate toothed leaves, and inodorous white flowers, either in clusters or alone. Much like the previous species. Has produced garden varieties.

*Philadelphus hirsutus, Nuttall. HaIry Mock-Orange. Slender native shrub from Eastern Tennessee region; leaves small, ovate, hairy or hoary, and sharply toothed; flowers small, white, single or 2 to 3 together.

Philadelphus inodorus, Linnaus. Shrub native of the high grounds in the South; leaves entire, ovate; "small flowers scattered at the ends of the diverging branchlets."

Besides the above there are other species, which, like these, come very close together, and also some well-known garden forms, as nivalis and subpleno.

Ribes. Currant and GoOseberry. Shrubs with alternate palmatelyveined and lobed leaves; calyx united with the ovary, and its lobes colored like a corolla; stamens 5 , on the calyx-throat; styles 2 , more or less united; the I-celled ovary becoming a juicy berry crowned with the dried flower.

Ribes alpinum, Linnaus. Alpine Red Currant. Shrub from the mountains of Europe and of Siberia; thornless; leaves obtusely 3 - to 5-lobed, hairy on upper and shining on lower surface; clustered flowers with small petals; anthers nearly sessile; fruit red. Runs into varieties.

Ribes aureum, Pursh. Buffalo or Missouri Currant. Thornless shrub, readily distinguished by its early yellow spicy-scented flowers and tasteless black or brown berries.

Ribes cereum, Douglas. A low thornless shrub, native of our Northwest; with small, sticky, heart-shaped, 3- to 5-lobed leaves, and greenish-white flowers; fruit somewhat glandular.

Ribes floridum, Linncus. WILd Brack Currant. Heart-shaped, 3- to 5-lobed leaves sprinkled with resinous dots, with 2 sets of teeth; flowers many in a drooping, downy cluster. Thornless. "

Ribes prostratum, L'Héritier. FetID CuRrant. Thornless shrub, native of the colder regions of the North; stems reclining; leaves heartshaped, acutely 5- to 7-lobed; flower-clusters upright; pale-red fruit and pedicles glandular bristly; bruised leaves and fruit emit an unpleasant odor.

Ribes sanguineum, Pursh. Red-Fiowered CURrant. A thornless shrub from our Northern coast; hairy, glandular, and sticky; the lobed leaves 
whitish duwny on the under surface: red fowers in drooping clusters : berries glandular, roughish, tasteless. The gardens have a number of varieties of this handsome shrub.

Ribes speciosum, Pursh. Showy Flowering Goosener ry. From Califurnia; leaves small and shining; flowers hanging bright red, I inch long; stamens projecting an inch, resembling (as Dr. Gray states) a Fuchsia. Shrub ro feet high, with strong, triple spines. "Berry dry, densely glandular bristly."

\section{SCROPHULARIACEAE. Figwort Family.}

Order (with us) mainly herbs, characterized by somewhat irregular, 2-lipped flowers with 4 stamens in pairs of different lengths and occasionally a rudi. ment of a fifth; pod 2-celled, with numerous seeds, placentæ in the axis. This large family has some bitter, tonic, astringent, and antiscorbutic properties (though for the most part it is devoid of marked properties), and has many showy flowers. Many of its species are root parasites. The Park has but a single conspicuous woody species

Paulownia imperialis, Siebold and Zuccarini. A tree with large heartshaped downy leaves; introduced from Japan. Hardy here. Flowers violetcolored, nearly 2 inches long, with an irregular lobed border, in large com. pound clusters; stamens 4 , shorter than the flower.

\section{SIMARUBACEEE. Quassia Family.}

Of which we have the single species

Ailanthus glandulosus, Desfuntrines; known ly its large compound leaves "of many oblique, lanceolate, entire, or sparingly sinuate leaves;" flowers small, greenish, in large branching clusters, the sterile with ro stamens and an abominable odor, the fertile with few or no stamens, but with 2 to j ovaries which develop into narrow, thin, winged fruit. From China.

\section{STYRACACE A. Storax Family.}

Trees or shruls with alternate, simple leaves; flowers with petals more or less united; the stamens twice as many as the petals, or more, usually united below; pistil of a I- to 5-celled ovary united wholly or in part to the calyx, and a single style.

Halesia. Swow-Drnp, SILver-BFll TrEe. The handsome white flowers in drosping clusters from the sides of the branches of the previous season; ovary and calyx united; stamens 8 to 16 ; fruit 2- to 4 -winged, with a single seed in each of the cells.

Halesia diptera, Linncus. Distinguished by its stamens being nearly free from each other, and by its 2-winged fruit. Native of Florida and Gicorgia. 
Halesia tetraptera, Linnaus. Native of the States to the south of us, characterized by its stamens being plainly united at base and by its 4 -winged fruit.

Styrax. STORAX. Flowers in the axils of the leaves, on the season's growth; the indistinctly toothed calyx united only with the base of the 3 -celled ovary; the dry fruit with a single cell.

Styrax Americana, Lambert. Native shrub with oblong smoothish leaves which are acute at either end.

* Styrax grandifolia, Aiton. Leaves 2 to 6 inches long, whitish downy on the under surface; flowers usually in clusters. Native shrub.

Styrax pulverulenta, Michaux. Leaves 2 inches long, lower surface somewhat scurfy; flowers fragrant and single or few in a cluster.

Symplocos. Flowers yellow, in short clusters; numerous stamens united in bundles, one of which is at the base of each of the 5 petals; fruit small, I-celled and I-seeded.

Symplocos tinctoria, L'Héritier. A small native tree or shrub with thick oblong leaves, which are sweet-tasted and eaten by cattle: whence the common name of SWEET-LEAF or HORSE SUgar.

\section{TAMARISCINEA. Tamarix Family.}

Foreign shrubs with scale-like leaves on slender branches, and with flowers (white or purplish) having 4 or 5 sepals and petals and as many or twice as many stamens, and a 3 -styled, I-celled, small capsule, which contains seeds with a tuft of hair at the apex. Our only genus is Tamarix.

* Tamarix Gallica, Linncus. French TAMARISK. Comes from the Mediterranean region; "flowers rosy purple," with 5 stamens and 5 petals.

Tamarix tetrandra, Pallas. "Has pale-pink flowers," with 4 stamens and 4 petals, and is from near Astracan, in Asia. A manna-like substance, much prized by the Arabs, is a product of another species of Tamarisk.

\section{THYMELEACEA. Mezereum Family.}

Shrubs with entire leaves and perfect flowers; no corolla, but with a corollalike calyx; stamens twice as many as the lohes of the calyx ; ovary free from calyx, I-celled, with a young seed hanging from the top of the cell. An order characterized by tough bark and acrid properties. The so-called Lace Bark is a product of the order.

Daphne. Calyx funnel-shaped or tubular, with a spreading border; style and 8 stamens not so long as the flower.

Daphne Cneorum, Linneus. Garland Flower, Trailing Daphne. Trailing or spreading shrub from Central Europe, with evergreen, smooth, 
lance-hinged leaves: flowers pink, in fraghant, flut-topped clusers terminating the branches; berries white. Hardy. Has some well-known varieties in cultivation.

Daphne Gwenka, Sicbold and Zuccarini. A twisted Japanese shrub, 2 to 3 feet high; leaves lanceolate, less than an inch long and a third as wide; lilac flowers appearing with the leaves about half an inch long; bark used in Japan as a ruhefacient, flowers as a cathartic, febrifuge, and anthelmintic.

Daphne Mezereum, Lirnaus. A low branching shrub from Europe, with purple or sometimes white flowers in clusters on the branches of the previous year, appearing before the smooth and lance-shaped leaves; berries red.

Daphne pontica, Linnaus. Pontic Daphnf, Twin-Frowered Spurge. Shrub from Asia Minor, with greenish-yellow flowers, each partial stalk of which bears 2 flowers.

Dirca. Leather-Wnon, Moose-Wood, Calyx simply tubular without any border; stamens 8 , these and the style longer than the flower.

Dirca palustris, Linnaus. Native shrub of wide geographical range, with very tough bark and white very soft wood; flowers yellow, emerging from dark, hairy scales before the leaves and in early spring; "berry reddish." Bush 4 to 8 feet high, with jointed branchlets.

\section{TILIACE $Æ$. Linden Family.}

Trees with large leaves and somewhat fragrant yellow flowers in a cluster on a slender stalk to which a conspictous leaf-like appendage is united.

Tilia argentea, De Candolle. Tree from Hungary, with scales inside the base of the petals; leaves white woolly underneath, and almost 4 times longer than the foot-stalks supporting them. Variety pendula of this species is in the Park.

Tilia Americana, Linnaus. American Linden, Basswood. One of the finest of our native trees; flowers with a scale before the base of each petal; leaves rather smooth on either surface.

Tilia Europra, Linnaus. European Linden. Flowers without scales on the base of the petals; heart-shaped leaves somewhat oblique, slightly downy on the under surface. A long-lived hardy tree in Europe, but shortlived and subject to insect enemies here. Tilia platyphylla of the gardens appears to be but a large-leaved form of this species. Of the European Linden there are several varieties, as aurea, laciniata, lutea, vitifolia.

Tilia heterophylla, Ventenat. White Linden. (Tilin alba, Michaux.) Flowers with scales in front of the stamens; leaves large, silvery white on the under surface. Most common along the mountains south of Pennsylvania.

\section{URTICACEA. Nettle Family.}

Herhs, shruls, or trees; without a corolla. Pistils and stamens usually separated (more or less distinctly associated in Ulmus, Planera, and Celis). Calyx not united to the single-seeded fruit. 
* Broussonetia. Tree with pistils and stamens separated; the male flowers in elongated clusters; female flowers (on same tree) in grlobular heads along with the bristly scales; mature ovary rising out of the calyx and forming a fleshy fruit; style $\mathbf{I}$.

Broussonetia papyrifera, Ventenat; is our only species. A native of Japan; heart-sinaped leaves entire or variously cut or lobed, rough on upper and downy on lower surface. Inner bark is used by the South Sea Islanders as a substitute for cloth.

Celtis. Trees with alternate, simple leaves, and stipules which usually fall early; styles on long stigmas, diverging, and crowning the $\mathbf{r}$ - to 2-celled fruit, which, when mature, is round and berry-like; lobes of the calyx and stamens 5 or 6, "lower flowers mostly staminate and clustered, upper ones fertile and mostly solitary on a slender peduncle." The AMERICAN HACKBERRY, Celtis occidentalis, Linnaus, is a native tree of middle size, with heart-shaped, taper-pointed, netted-veined leaves; fruit round and somewhat sweet. Also known as NetTle-TREe.

Maclura. Male and female flowers on different trees, the former in elongated clusters, the latter crowded in a globular head, sepals 4, unequal; mature fruit a greenish or greenish-yellow ball the size of an orange. Hence the name of OSAGE ORANGE given to

Maclura aurantiaca, Nuttall; our native, large, spiny tree, which has yellow wood and lance-shaped entire glosey leaves. From the Arkansas region, where it is called BOIS D'ARC. Here it is kept trimmed down to hedge size.

Morus. Trees with the pistils and stamens on different flowers of the same tree and both forming elongated clusters; sterile flowers with 4 stamens ; fertile flowers when ripe aggregated into a fleshy mass longer than, but somewhat resembling, a blackberry.

Morus alba, Linncus. White Mulberry. Leaves smooth, oblique at base; fruit white, or light red, on slender stalks. Introduced from China during the "silk-worm mania."

Morus nigra, Limnaus. Black Mulberry. A middle-sized tree from Persia, with rough leaves and well-flavored dark-red fruit (round or nearly round) on short stalks.

Morus rubra, Linnaus. RED MulberRy. Native tree in the Park, of small size, with roundish, heart-shaped, toothed leaves, which are rough on upper and downy on lower surface; fruit long, dark purple. A good timber so far as quality is concerned, but too small and scarce to be of any great service.

Planera. Resembling Ulmus (see below), but has calyx only 4- to 5lobed; "flowers appearing with the leaves in small axillary clusters ;" fruit a wingless nut.

* Planera aquatica, Gmelin. Planer-Tree. Native, with small, ovate leaves and a rough fruit, stalked in the calyx. 
Ulmus. Er.M. Tree with perfect or nearly perfect flowers; calyx 4- to 9cleft, containing 4 to 9 long stamens, and a 2 -celled when young, a $\boldsymbol{I}$-celled when old, fruit, which is winged all around; flowers in clusters on branches of the previous year, appearing before the leaves. A group of valuable trees.

Ulmus alata, Michanx. Whahoo, Wixger F.LM. Small tree, native to the west and south of us; flowers on slender, jointed stalks; fruit oval, 2touthed; leaves small, and branches with corky ridges. Notch of fruit reaching almost to the seed-bearing centre.

Ulmus Americana, Linneus. Amfrican White Er.M. Large native tree, with flowers and fruit much as in the last, except that the teeth of the fruit close up the notch, leaves also larger and thinner; branches ascending, branchlets recurved, slender.

Ulmus campestris, Smilh. ENGi.rsh Elm. Large tree, native of the Oid World, very varialle in form and in its smaller characters. Has "rather short horizontal or ascending branches; leaves 2 to 4 inches long, mostly or snon smooth." It has produced many varieties, among which the Park has fastigiata, pendula, horizontalis, and punctata.

Ulmus fulva, Michaux. Strpery Erm. A middle-sized tree, native of the Park. I eaves rough on the upper and smoother on the under surface; seed-bearing part nearly or quite in the centre of the fruit; flowers not on slender stalks; buds rusty brown; wood tough, red, inner bark abounding in mucilage, used for poultices and the like.

* Ulmus montana, Smilh. Wych ElM. Too near Ulmus campestris, from which it differs chiefly in having the seed-bearing portion of the fruit in the centre and not near the notched end. Introduced under the name of Sсотсн ELM.

Ulmus suberosa, the EUROPEAN CORK ELM, is regarded as a variety of Ulmus campestris.

* Ulmus racemosa, Thomas. CoRky White ElM. Native tree, loving river-banks; leaves smnoth, flowers on slender, jointed stalks; fruit oval, hairy-margined; bud-scales and branches hairy or downy.

\section{VERBENACEA. Verbena or Vervain Family.}

Petals united into a more or less irregular 2-lipped corolla; stamens of different lengths; ovary 2- to 4 -celled, splitting when ripe into 2 to 4 oneseeded nutlets. An orcler furnishing many handsome flowers and some useful products. The genuine Indian Teak is a large tree which belongs here (Teclona grandis). The order has few if any real remedies.

Callicarpa. Nearly regular flowers in a cluster in or above the leaf-axils; calyx 4-to 5-lohed; the short corolla broadly tubular, 4-to 5-lobed, and shorter than the 4 nearly equal staniens.

Callicarpa Americana, Linnaus. French Mulderry. Grows from Virginia snuthward; the oblong torthed leaves are scurfy duwny on the under surface. Shrub ro feet high; flowers bluish. 
Callicarpa purpurea, Fussien. From China, and differs from the above in being covered with resinous glandular dots, and by the flower-clusters rising up alove the axils of the leaves. The anthers protruding from the flower are densely glandular.

Lippia citriodora, Kunth. Lemon Verbena. (Aloysia citriodora of the gardens.) Shrub from Chili; with small, fragrant, white or blue flowers in long slender clusters; flower with the lower 3-lobed lip larger than the upper 2-lobed one, longer than the stamens; ovary 2-celled and 2-seeded.

Vitex. Irregular flowers in the axils of the divided leaves, lower lip 3parted, upper 2-lobed; 4 stamens and style longer than the corolla; ovary 4 -celled, the stone at maturity 4 -celled.

Vitex Agnus-castus, Linneus. Chaste Tree. From Southern Europe. Has leaflets entire, and flowers in sessile clusters towards the ends of the branches. Not hardy here.

Vitex incisa, Lambert. Shruh, from China; with leaflets cleft or cut, and flower-clusters on peduncles. Hardiness here not absolute. 


\section{N D E X."}

Ahele so.

Abies, 14 .

Acer, 82.

Asculus, 83.

Albizzia, 59.

Alder, 8.

Black, 6.

White, 5I.

Allspice, Carolina, 10.

Almond, 73.

Divarf, 73.

Flowering, 73 .

Alnus, 8 ,

Althaea, Shrubhy, 66.

Amelanchier, 70.

Amorpha, 59.

ANACARDIACEA, 5.

Andromeda, 50.

ANoNACE.E, 6.

Apple, 74.

American Crab, 74.

Garland Crab, 74 .

AQUIFOLIACE.E, 6 .

Aralia, 6.

ARALIACEA, 6.

Amucaria, 17.

Arbor Vita, 37.

American, 37.

Chinese, 18.

Decurrent-Leaved, 26.

Giant. 37.

Hatchet-Leaved, 37 .

Nootka Sound, 38.

Siberian, 38.

Standish's Japan, 38.

Tartarian, 38 .

Weeping, 18.

Arbutus, Trailing, 5x.

Ash, 67.

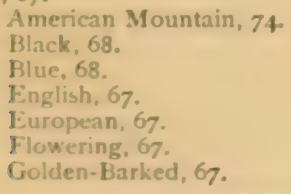

Ash, Green, 68.

Northern Prickly, 79.

Red, 67.

Single-Leaved, 67.

Southern Prickly, 79.

Water, 68.

White, 67 .

Willow-Leaved, 67 .

Asimina, 6:

Aspen, American, 8o.

Large-Toothed, 80.

Aucula, 39.

Azalea, 53.

BARBERRY FAMILY, 7.

Basswood, 89.

Bay, Carolina Red, 58.

Red, 58.

Sweet, 65.

Bayberry, 66.

Beam-Tree, Intermediate White, 75.

BEAN FAMII,Y, 59.

Beech, 4I.

BERBERIDACEA, 7.

Berberis, 7.

Berchemia, 69.

Berry, Avignon, 70.

Buffalo, 50.

Coral, 13.

Ink, 6.

Silver, 49.

Betula, 8.

Betulacex, 8.

BIGNONiA FAMILY, 9.

BIGNONIACEA, 9.

Bilsted, 55.

Biota, I8.

Birch, 8.

BIRCH FAMILY, 8.

Bitternut, 56.

Bitter-Sweet, Climbing, 14.

Blackberry, 76.

Black-Jack, 45.

Bladder. Nut, 8\$.

American, 84 .

European, 84 .

1 We have given but few technical specific names in the index, as they are arranged alphatetibully usicu tiecir resjective geners. 
Bladder Senna, 6o.

Bois d'Arc, go.

Box, 54.

Bramble, 76 .

Heart-Leaved, 76.

Linden-Leaved, 76.

Shrubby-Leaved, 76.

Broom, Scotch, 6r.

White, 6I.

Broussonetia, 90.

Buckeye, 83

Fetid, 83 .

Ohio, 83.

Purple-Flowered, 83.

Red, 84.

Sweet, 83 .

Buckthorn, 70.

Alder, 69.

European, 70.

Sea, 49.

Staining, 70 .

BUCKTHORN FAMILY, $6 \%$.

Bush, Benjamin, 58 .

Burning, $x_{4}$.

Button, 79.

Hobble, 13.

Butternut, 57.

Buxus, 54.

Callicarpa, 9I.

Calluna, 50.

CalyCanthaCEÆ, ro.

CAMELliaCe.E, Io.

CAPRIFOLIACEE, IO.

Caragana, 59.

Carpinus, 40.

CASHEW FAMILY, 5.

Cassandra, 5I.

Castanea, 40.

Castor-Oil Plant, 55.

Catalpa, 9.

Ceanothus, 69. Oval-Leaved, 69 .

Cedar, Bermuda, $2 \mathbf{I}$.

Pencil, 2 I.

Prickly, 23.

Red, 25.

Virginian Red, 25.

White, 2I.

Cedrus, 19.

Celastrace.e, I3.

Celastrus, 13.

Celtis, 9o.

Cephalanthus, 79 .

Cephalotaxus, 19.

Cercis, 60.

Cherry, 73.

Choke, 74.

Dwarf, 74 .

Red, 73.

Wild Black, 74 .

Wild Red, 73.
Chestnut, 40, 4r.

Chim onanthus, ro.

Chinquapin, 4I.

Chionanthus, 66.

Chokeberry, 74 .

Cinquefoil, 73.

Cladrastis, 60.

Clethra, 5I.

Coffee-Tree, Kentucky, 62.

Colutea, 60.

Comptonia, 66.

CONIFER E, I4.

Corchorus, 72.

CORnaCe.E, 39.

Cornel, 39, 4 .

Cornus, 39.

Corylopsis, 55 .

Corylus, 4r.

Cotoneaster, 7I.

Cottonwood, Angled, 80.

Cratæegus, 7I.

Cross-Vine. 9.

Cryptomeria, I9, 20.

Cucumber-Tree, 64 .

Cunninghamia, 20.

Cupressus, 20, 2 I.

Cupuliferæ, 40.

Currant, 86.

Alpine Red, 86.

Buffalo, 86.

Fetid, 86.

Indian, I3.

Missouri, 86.

Red-Flowered, 86.

Wild Black, 86.

CUSTARD-APPLE FAMILy, 6.

Cypress, 20, 2 I.

Bald, 35

Thready Japan, 33.

White, 37.

Yellow, 37.

Cytisus, 60.

Daphne, 88.

Desmodium, 6r.

Deutzia, $8+$.

Diervilla, Ir.

Diospyros, 48 .

Dirca, 89.

Dockmackie, 13 .

Dogwood, 39.

Striped, 82.

DOGWOOD FAMILY, 39.

EBENACF, E, 48.

EBONY FAMILY, 48.

ELÆAGNACEÆ, 49.

Elaeagnus, 49.

Elder, 12. Box, 84

Elm. Corky White, 9r. European Cork, 9I. 
EIm shmers. gr.

Winged, or.

Winch, w.

linigar. 51 .

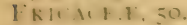

Euonymus, it.

EUHHURBACE.

Exochorda, 72.

Fagus. 4x.

Fern, Sweet, 66.

FIC:WURT FAMILY, 87.

Fir, 26.

A pollo Silver, 26.

Arctic Spruce, 17.

Balm of Gilead, 26.

Cilician Silver, 27.

European Silver, 28.

Fraser's Silver, 27.

Great Californian Silver, 27.

Indian Spruce, 17.

Intermediate, $\mathbf{x} 6$.

lapan Silver, 27.

1.

Nordmann's Silver, 28.

Pinsapo, 28.

Plum, 33.

Pompous Silver, 27.

Red, 27.

Red Spruce, I7.

Scotch, 33.

Siberian Silver, 28.

¿pright Indian Siiver, 28.

Teitch's Silver, 28.

Webb's Indian, 28.

Western Silver, 26.

Five-Finger. 73.

Forestiera, 66.

Forsvthia, 67.

Fothergilla, 55 .

Frascula, rog.

Frasumus 67.

Fuss and Feathers, 5.

Genista, 61.

Ginkgo, 35 .

Givseng FAMILY, 6 .

Gleditschia, 6r.

Golden-Chain, 62.

Gooseberry, 86.

Showy Flowering. 87.

Grape, Mountain, 7 .

Oregon, -

Green-Weed, Dver's, 6r.

Gymnocladus, 62 .

Hackberry, American, go.

Hackmatack, 25.

Halesia, 87.

Haseamelace.é, 55 .

Hamamelis, 55.

Hardhack, 78.
Haw, Summer, 7 r.

Yellow, 71.

Hawthorn, 7 I.

English, 72.

Hazel-Nut, 4 r.

HEATH FAMILY, 50

Heather, 50.

Hibiscus, 65

Hickory, 56.

Broom, 57.

Hippophre, 49.

HOLI.Y FAMILY, 6.

HOLLYHOCK FAMILY, 65.

Honey-Locust, 6 I. Caspian, 6r.

Chinese, $6 \mathrm{r}$.

Common, 62 .

Large-Thorned, 6I. One-seeded 6r.

HONEYSLCKLE FAMILY, IO.

Honevsuckle, Bush, II.

Hornleam, 40.

$$
\text { Hop, 4r. }
$$

Horse-Chesinut, 83 .

Common, 83 .

Dwarf. 83.

Small-Flowered, 83

Hydrangea, 85.

Oak Leaved, 85.

HYPERICACE.E, 56 .

Ilex, 6.

Indigo, False, 59.

Iron-Wood, 40.

Itea, 85 .

Juniper, 2I.

Bushy Indian, 22.

Caucasian, 23.

Common, 22.

Crowded-Leaved, 22.

Davurian, 22.

llense Indian, 22.

Glaucous Chinese, 24.

Globular, 22.

Globular-Fruited, 24.

Hedgehog, 22.

Japan, 23.

I arge-Fruited, 23.

Loose-Growing, 22.

Oblong-Fruited, 23.

Phoenician, 23.

Plun-Fruited, 22.

Prostrate, 24.

Recurved-Branched, 24.

Rocky Mountain, 23.

Savin, 24.

Scaly-Leaved Nepal, 24

Siberian, 23.

Spanish, 25.

Stiff I eaved Japan, 24

Tall Crimean, 22. 
Juniper, Thick-Barked, 23.

Western, 23.

Yew-Leaved, 24.

Juniperus, 21.

JUGLANDACEA, 56.

Juglans, 57.

Kalmia, 5 I.

Kerria, 72.

Kinnikinnik, 40.

Kœlreuteria, 84.

Laburnum, 62 .

Lagerstrœmia, 64 .

Lambkill, 5 I.

Larch, 25.

Altaian, 26.

American, 25.

Chinese, 25.

Dahurian, 25.

European, 25.

Golden, 33

Kamtschatka, 26.

Lyall's, 26.

Sikkim, 26.

Slender-Scaled, 26.

Larix, 25.

LAURACE.

Laurel, 5 I.

Cherry, 73.

Ground, 51.

LAUREL FAMILY, 58.

Lead-Plant, 59.

Leather-Leaf, $5 \mathbf{I}$.

Leather-Wood, 89.

Ledum, 52.

Leiophyllum, 52 .

LEGUMINOS $Æ, 59$.

Leucothoe, 52.

Leycesteria, $\mathbf{I}$.

Libocedrus, 26.

Ligustrum, 68.

Lilac, 68.

Common, 68

Josika's, 68.

Persian, 68.

Linden, American, 89.

European, 89.

White, 89 .

LINDEN FAMILY, 89.

Lindera, 58.

Lippia, 9r.

Liquidambar, 55 .

Liriodendron, 64 .

Locust-Tree, 62.

Lonicera, Ix.

LOOSESTRIFE FAMILY, 63.

LYTHRACE.E, 63.

Maclura, 9o.

MADDER FAMIIY, 78.

Magnolia, Ear-Leaved, 64.
Magnolia, Great-Flowered, 68.

Large-Leaved, 65.

Purple, 65.

Umbrella, 65 .

MAGNOLIACEÆ, 64 .

Magnolia FAMILY, 64 .

MALLOW FAMILY, 65.

MALVACEA, 65.

Maple, 82.

Ash-Leaved, 84.

Black Sugar, 83 .

Broad-Leaved, 82 .

English, 82.

Mountain, 83 .

Norway, 82 .

Obtuse-Leaved, 82.

Red, 83 .

Rock, 83 .

Silver, 82,83 .

Soft, 82 .

Sugar, 83 .

Sycamore, 83 .

White, 83 .

May-Flower, 5 I.

Meadow-Sweet, Common, 78.

Douglas', 77.

Menziesia, 52.

MEZEREUM FAMILY, 88.

Mock-Orange, $73,85,86$. Hairy, 86.

Large-Flowered, 86.

Mocker-Nut, 57.

Moose-Wood, 82, 89.

Morus, go.

Mulberry, Black, 90.

French, 9I.

Red, 90.

White, 90.

Myrica, 66.

MYRICACEAE, 66.

Myrtle, Crape, 64 .

Sand, 52.

Wax, 66.]

Negundo, 84.

Nettle, Family, 89.

Nettle-Tree, 90.

Nine-Bark, 78.

Nutmeg, California, 38.

Nyssa, 40.

Oak, 42.

Barren, 45.

Barren Scrub, 42.

Bartram's, 43 .

Bear, 44.

Black, 43.

Black Scrub, 44

Box White, 47.

Bur, 44 .

Burgundy, 42.

Chestnut, 45 . 


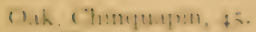

(oth, $:$.

Enclate :-

Fus :m: u1, 4"

litwotman Fivergreen, it

licerse on, 43

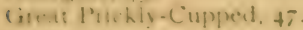

il.ally :4

Hungarlan. 4 S.

I. ar: Flowetrd, 44

I. $4 a+4+1,4$.

Lause!-Leared it.

Ixas +4 .

l.1. 40.

M.ugedian, 4 .

Mancr (Mereul), +4.

(1) renem, +4 .

Ine 4 .

l.w. 47

Pvrraran, ti.

ked 4".

knek i Hu-tnut, 45.

Rowigh, 47.

Runuing, 45.

Simlet, 43 .

Shungle. 44

-ivatia 43.45

Six

Swame, IVhise. 42 .

lurke-1. 42

'Turkish, 42 .

Turner's, 47

Upland IVillow, 43.

Water, 42.

Wviliss 45

II Hite $\$ 2$.

Yellos. 45

Yellow-Barked, 43

Yellow Chestnut, 45 .

OAK FaMiLY, 40.

Oles, 68.

OI.EACEA, 66.

OLEASTER FAMIIY, 49.

Olive, 68.

False, 49

OLIVE FAMII.Y, 66.

'Heage Oraugs. Po.

(1)...r, Rerl, +o.

(1) toy $4 \mathrm{t}$.

1)xintoum, 53 .

Patmo-Chr-tl. 55

P'ang o

Padersout of

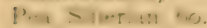

Peach, 73.

Pear, 74.

Willow-Leaved, 75.

Pecan-Nus, 56.

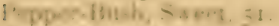

Pepoendere 40.

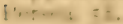

Persimmon, 48.

Phellodendron, 79.

Philadelphus, 85.

Picea, 26.

Pignut, 57

Pine, Austrian, 29.

Awn-Coned, 29.

A vacahuite, 29.

Banks, 29.

Chili, 18.

Chinese, 3r.

Corean, 30.

Corsican, 31.

Dense-Flowered Japan, 30.

Elliott's, 30.

Frankincense, 33.

Gerard's, 30.

Giant, 31.

Gray, 29.

Jersey, 30.

I_ambert's, 3 I.

Loblolly, 33.

Lofty Bhotan, 30 .

Mountain, 3 I.

Mugho, 31 .

Northern, 29.

Nut. 30.

Oldfield, 33.

Oregon Pitch, 30.

Piñon, 30.

Pitch, 32.

Pyrenean, 32.

Red, 32.

Rocky Mountain White, 30.

Sap, 32.

Scotch, 33 .

Scrub, 29, 30.

Short-Leaved Yellow, $3 \mathrm{r}$

Small-Flowered Japan, 3r.

Sugar, 3 I.

Swiss Stone, 29.

Table Mountain, 3I.

Torch, 33.

Twisted-Branch, 29.

Umbrella, 35.

Weymouth, 33.

White, 32.

Yellow, 31.

PINE FAMILY, I4.

Pink, Jersey, 52.

Pinus, 28.

Pinxter-Flower, 53.

Pirus, 74.

Plane, American, 69 Oriental, 69.

PLANE.TREe FAMII.Y, 69.

Planera, go.

Platanacere, 69.

I'latanus. 69.

Plum, 73.

Beach, 73.

Chickasaw, 73 
Plum, Red, 73.

Wild Yellow, 73.

Pidocarpus, Japan, 33.

Poplar, 80.

Balsam, 80 .

Black, 8o.

Necklace, 80 .

White, 80 .

Yellow, 64

Potentilla, 73 .

Prim, 68.

Privet, 68.

Prunus, 73.

Pseudo-Larix, 33.

Pterocarya, 57.

Pyrus, 74.

QUASSIA FAMILY, 87.

Quercitron, 43.

Quercus, 42.

Quince, Japan, 75.

Raspberry, 76 .

Dwarf, 77.

White-Flowered, 77.

Red-Bud, 60.

Red-Root, 69.

Redwood, California, 35 .

Retinospora, Club Moss-Like, 34 .

Fern-Like. 33.

Flat-Branchleted, 34 .

Heath-Like, 33.

Obtuse-Leaved Japan, 34.

Pea-Fruited, 34.

Plum-Like Japan, 34 .

Slender, 34.

Squarrose-Leaved, 34.

RHAMNACE 2,69

Rhamnus, 70 .

Rhododendron, 53, 54 .

Rhus, 5 .

Ribes, 86.

Ricinus, 55.

Robinia, 62

Rosa, 75

RUSACE E, 70.

Rose, 75 .

Cinnamon, 76 .

Climbing, 76 .

Dog, 75 .

Dwarf Wild. 76

Early Wild. 76

Evergreen, 76 .

Miny-Flowered, 76.

Prairie, 76.

Swamp, 75 .

Yellow, 76 .

Rose-Acacia, 62

ROSE FAMILY, 70.

Rowan, European, 74.

RIIBACEA, 78.

Rubus, 76.
RUE FAMILY, 79.

RUTACE $Æ, 79$.

Str. JOHN'S-WORT FAMILY, 56

SAILACE, E, 80.

Salisburia, 35 .

Salix, 8I.

Sallow-Thorn, 49.

Sambucus, I2.

SAPINDACEÆ, 82.

Sassafras, 58.

SAXIFRAGACEAE, 84

SAXIFRAGE: FAMILY, 84.

Sciadopitys, 35.

SCROPHULARIACE $Æ, 87$.

Sequoia, 35.

Service-Berry, 70 .

Shad-Bush, 70

Shagbark, 56.

Shellbark, 56 .

Shepherdia, 49.

Canadian, 50.

Shrub, Sweet-Scented, Io.

Silk-Flower, 59.

Silk-Tree, 59.

Silver-Moon, 49.

SIMARUBACE $Æ, 87$.

Skimmia, 79

Smoke-Tree, 5.

Snowberry, $\mathrm{I}_{3}$

Snow-Drop, 87

SOAPBERRY FAMILY, 82.

Sophora, 63 .

Sorrel-Tree, 53.

Sour-Wood, 53

Spice-Bush, $5^{8}$

Spindle-Tree, 14.

Spiræa, 77

Birch-Leaved. 77

Elm-Leaved, 78.

Plum-Leaved, 78

Spruce, I4

Alcock's, 15.

Black. I7.

California Hemlock, 16.

Double, I7.

Douglas', I5.

Engelmann's, I6.

Hemlock I5

Indian Hemlock, I5.

Japan Hemlock, 17.

Menzies', I6.

Norway, 16.

Obovate-Coned, I7.

Oriental, 17.

Patton's Giant, I7.

Single, I5.

Tiger's-Tail, 17.

White, 15.

SPURGE. FAMILY, 54.

STAFF-TREE FAMILY, I3.

Stagger-Bush, 50 . 
Simplule. 8.4.

sterpie-Bu-1, -8 .

Sis: is. 8-

STUK IX FAMILY, 87.

Simwberry-Bush, American, It.

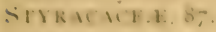

sumach, 5.

SUMACH FAMLY, 5 .

Supple-lash for.

- sweenturier 76

Sweetbrier-Gum, 55.

Siser:t Gale, 66.

Silli, Gale FAMHLY, 66.

Sicrmule, ato.

Simphurempur, 13.

Simplocos, 88.

Syringa, 68,85 .

Tacamahac, 80 .

TAMARISCINE.E, 88.

Tamarisk, French, 88.

Tamarix, 88.

Taxodium, 35.

Taxus, 36.

Tea, Labrador, 52. New Jersev, 69.

TEA FAMILY, 10.

Tecoma, 9.

Tetranthera, 58.

Thvmeleacez, 88.

Tick-Trefoil, 6r.

Tilia, 89.

TILIACE.E, 89.

Thorn, Black, 72.

Cockspur, 71.

Dwarf, 72.

Eastern, 72.

Evergreen, 72.

Parsley-Leaved, 71.

Scarlet-Fruited, 7I.

Tansy-Leaved, 72.

Washington, 71 .

Thuiopsis, 37.

Thuja, 37 .

Torreya, 38 .

Nutbearing. 38 .

Tree, Big. 35.

Chaste, 91.

Chinese Lace-Bark, 29.

Cranfwny. 13.

Fringe, , ,

lusid exo.

Maiden-Hair, 35 .

Pea, 59.
Tree, Planer, no.

Rowan, 74.

Silver-Bell, 87.

Sour Gum, 40.

Toothache, 79.

Tulip. 64.

Wayfaring. 13.

Trefoil-Tree, Bean, 62.

Trochodendiron, 65 .

Trumpet-Creeper, 9.

Trumpet-Hlower, 9.

Tupelo, 4o.

Ulmus, 9 r.

URTICACE E, 89.

Verbina Family, gi.

Verbena, Lemon, 9x.

VERBRNACEE, QI.

VERVAIN FAMILY, 9I.

Viburnum, 13.

Vitex, 9i.

Walnut, Black, 57 .

English, 57.

Manchoorian, 57.

Wax-Work, I4.

Whahoo, 9I.

Whitewood, 64 .

Wicky, 5I.

Willow, Black, 8r.

Glaucous, 8r.

Heart-Leaved, $8 \mathbf{I}$.

Long-Leaved, $8 \mathbf{x}$.

Sallow, 8x.

Shining, $8 \mathrm{r}$.

Three-Stamened, 82 .

Weeping, 8r.

White, $8 \mathbf{I}$.

Winterberry, 6. Smooth, 6.

Wistaria, 63 .

WITCH-HAZEL FAMILY, 55.

Yellow-Wood, 6o.

Yew, 36.

Abrupt-Pointed, 37.

California, 36.

Canadian, 36.

Short-Leaved Japan, 36 .

Stinking, 38.

Yulan, 64 .

Zanthoxylum, 79. 



le

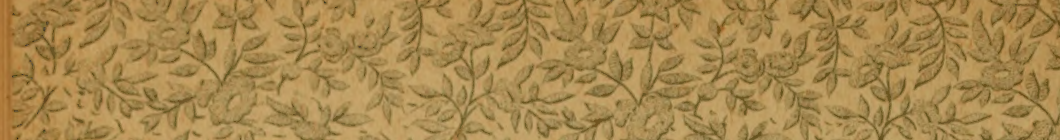

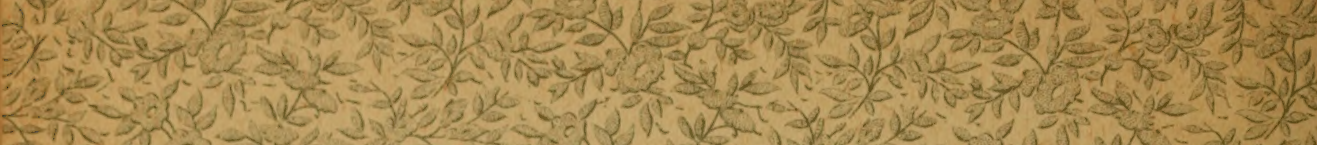

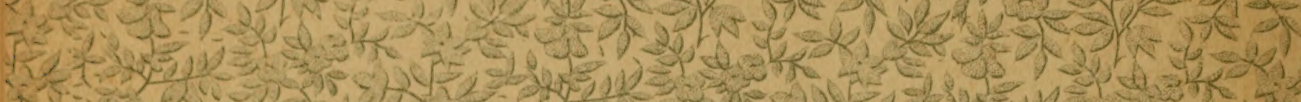

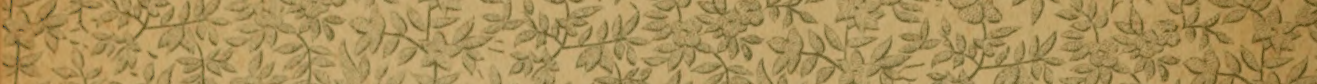

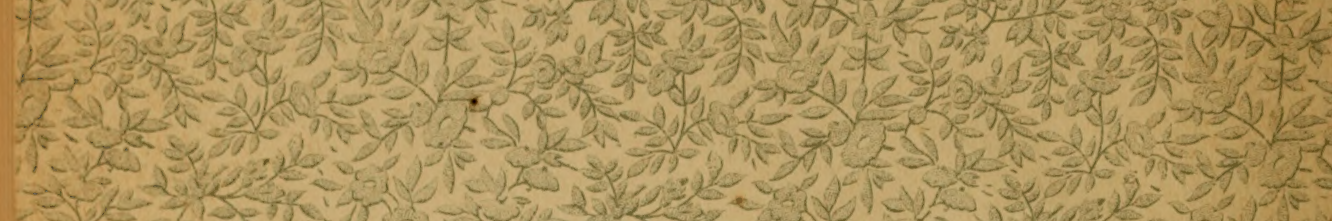

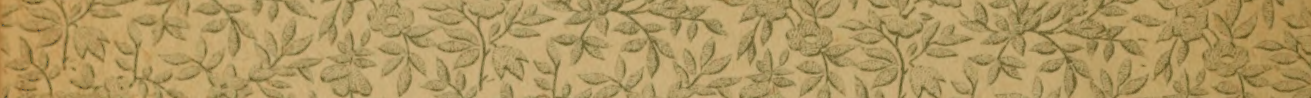

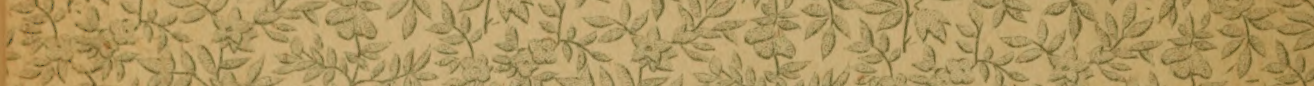

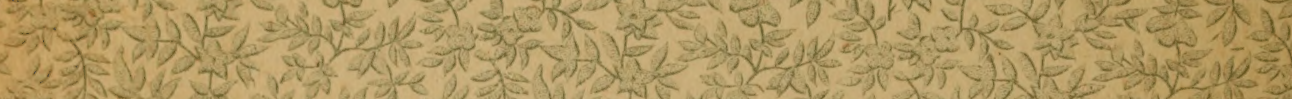
2) 3) 3 (2)

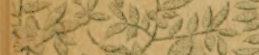
If

(4. $\frac{1}{2}$

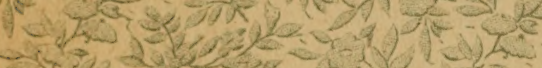

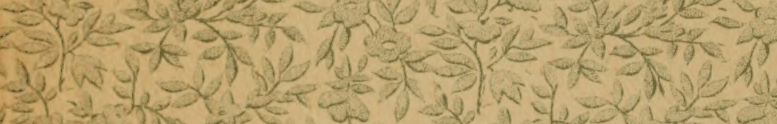

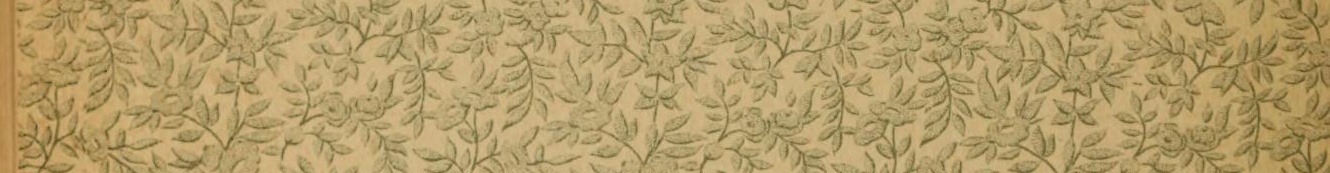

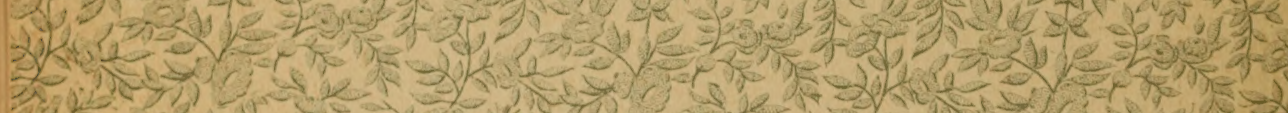
S-1,

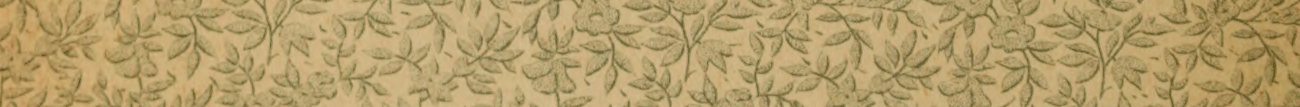
1.5.

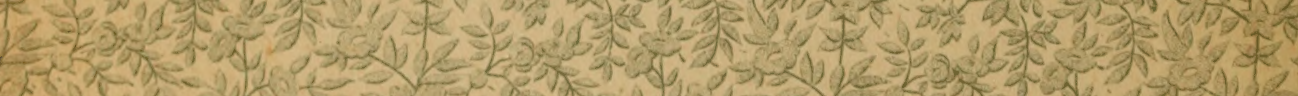

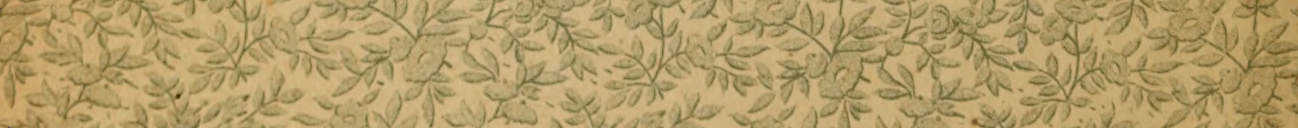

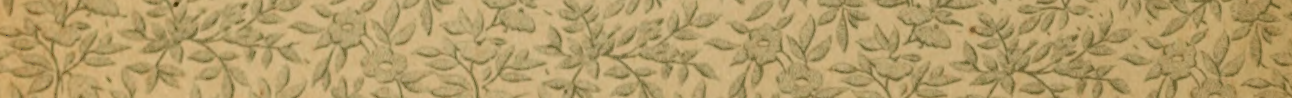

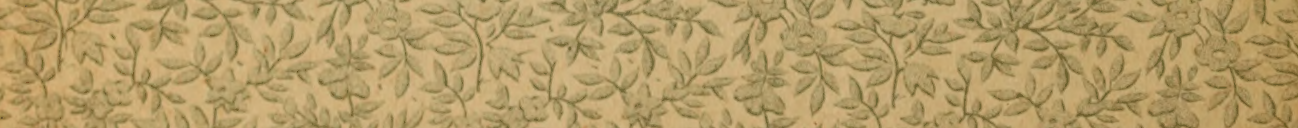
S. 

